Historic, archived document

Do not assume content reflects current scientific knowledge, policies, or practices. 


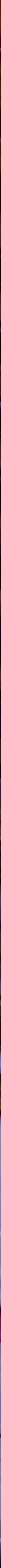




\section{THE THREE WARRANTS.}

Ist.-That our Seed shall be what it purports to be in kind and quality; and we hold ourselves ready to refill the order anew, gratis, in other Seeds should they prove to be defective in either respect.

2d.-That all money sent for Seeds will reach us, with the single proviso: That all sums to the amount of One Dollar and upwards, be sent in the form of a Post Office Order, or Registered Letter, on Mercersburg, Pa.

3 d. - That the Seeds ordered shall reach everyone of our customers, thus taking all the risks of the business upon ourselves.

\section{SECOR'S EXCELSIOR WEEDER, NO. 4.}

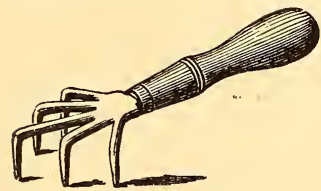

Patented 1869.

\section{PRICE TWENTY CTS.}

BY MAIL, POST-PAID, TWENTY-FIVE CENTS.

J. M. PHILIPS \& SONS., MERcERSBURG, PA.

\section{CHAMBERSBURG NURSERIES.}

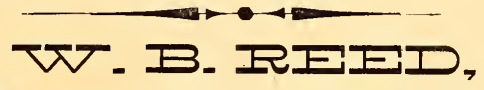

\section{NURSERYMAN AND ROSE GROWER,} Chambersburg, Franklin County, Pa.

Evergreens, Shrubbery, Fruit and Ornamental Trees, Rose, Grape Vines and small

$\begin{array}{ll}\text { Fruits } & \text { Correspondence solicited. Orders by mail promp } \\ \text { rily filled. } & \text { Catalogues and Price Lists furnished on application. }\end{array}$

\section{RISING SUN NURSERY.} AT MERCERSBURG, FRANKLIN COUNTY, PA.

\section{J. O. MARTIN}

Would respectfully call the attention of the public to his Superior Stock of

Fruit and ornamental Irees, Grape Vines, Vegelable Plants, etc., etc. 



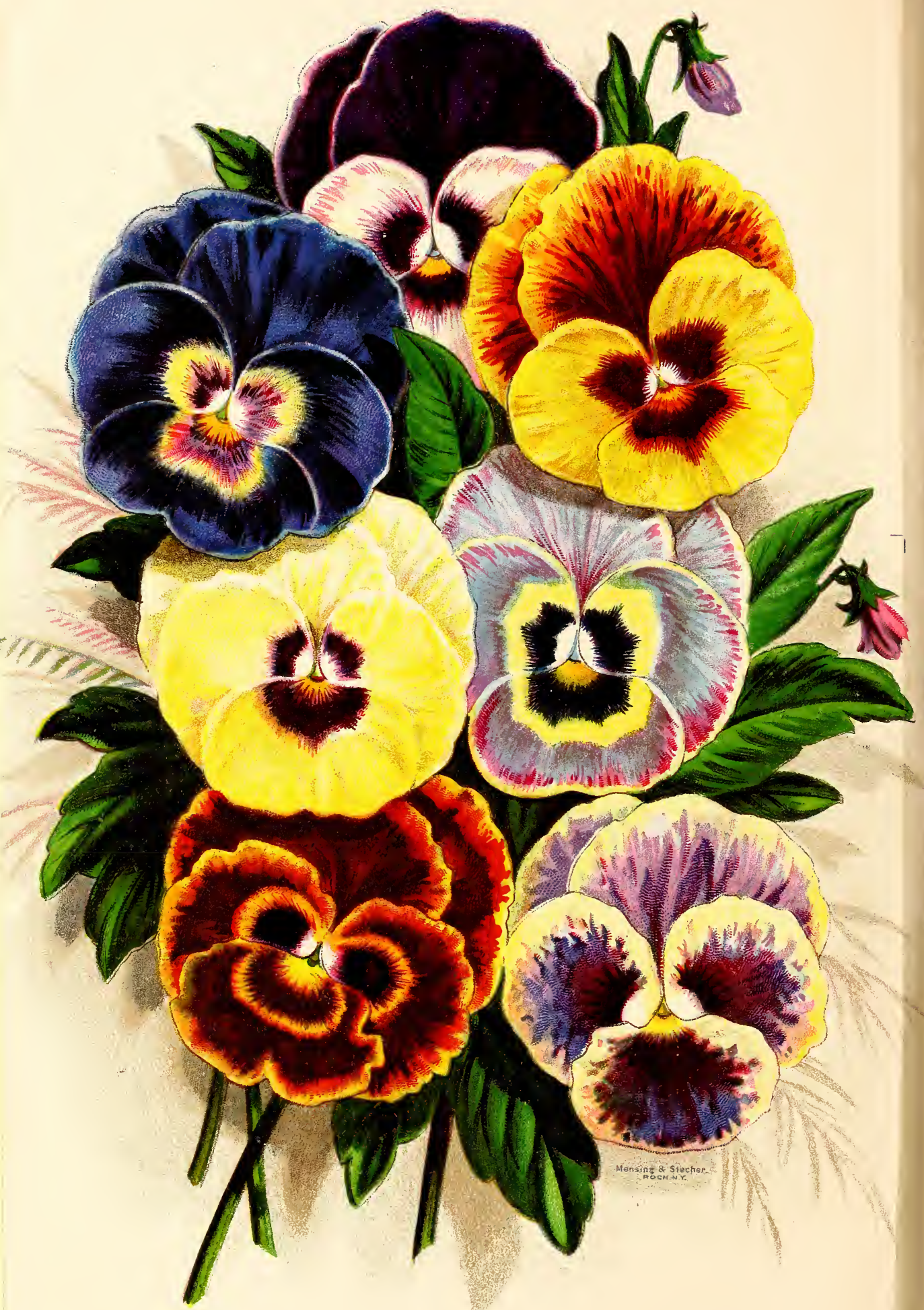




\section{DIRECTIONS}

\section{一FOR THE- \\ Cultivation OF VegeTables.}

Success in cultivating all vegetables, is certain, just in proportion as sufficient space is given to grow in, proper tillage bestowed, and the necessary supply of light and air afforded. These conditions met, the crop will be heavy and the quality superior.

In the directions found in the Catalogue we name the least space required by the different varieties. This has been done in view of the limited size of many gardens, which necesitates economy of ground. Where the garden will allow it, more liberal space should be given.

Having set apart sufficient space, give the ground a thorough preparation. Deep culture is one great secret of success. Plough and subsoil ; or if the spade is used, dig down at least sixteen inches.

It is important that the ground be well drained.

All crops succeed better when planted and cultivated in drills and rows, rather than broadcast. By so doing, time, expense and trouble, will be saved. Weeds must be thoroughly eradicated, and the surface of the ground kept open and loose, if you wish to raise a superior, or even a remunerative crop. To accomplish this, the hoe is your best helper, and should be kept constantly at work.

The same kind of crop should not occupy the same ground year after year. After manuring well, such crops as grow above ground (Cabbage, Peas, Potatoes, and the like,) follow next year with root crops (Carrots, Parsnips, \&c.,) which will not require so much manure.

We need scarcely suggest the advantage to be derived by an early starting of vegetables in hot-beds. The trouble is very slight as compared with the gain in time and the satisfaction thus secured.

All these suggestions are of practical importance, and if acted upon will secure early and abundant crops. 


\section{Useful Tables.}

The following tables may be useful to the Farmer and Gardner in showing the number of plants or trees that can be raised to an acre of ground; also the quantity of seed required for an acre, with the number of plants that can be grown from an ounce of seed, should the weather be favorable and the seed be preserved from the destruction of insects. We would, however, recommend a slight increase in the quantities, to allow for these contingencies. The number of square feet contained in an acre is 43,560 .

\section{Number of Plants or Trees to the Acre at Given Distances.}

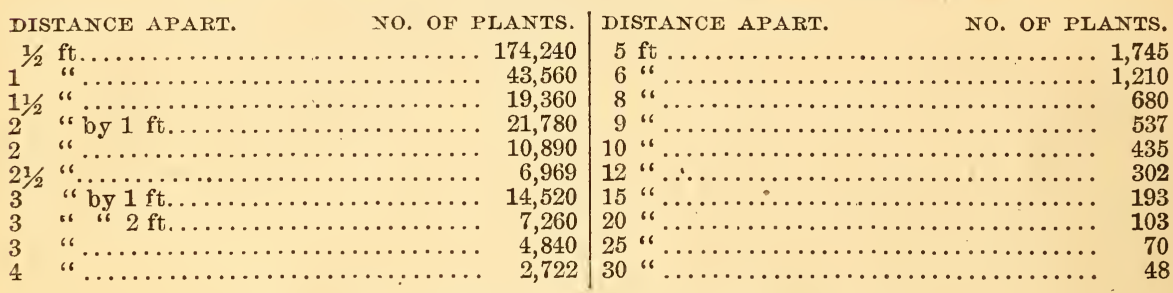

Quantity of Seed Usually Sown to the Acre.

Beans, Dwarf, in drills......... 11/2

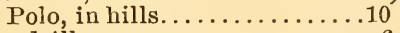

Beet, in drills................. 6

Broom Corn, in hills............. 8

Cabbage in beds to transplant...... $1 / 2$

Carrot, in drills.................

Corn Salad, in drills.............6 6

" Field, in hills............... 6

" Sweet, in hills.................. 8

" "or Field (for soiling, drills 1

" " " " " broadcast 2

Cucumber, in hills............... 2

Melon, Musk, in bills............. 3

"6 Water, in hills.............

Onion (for bulbs, ) in drills........6 6

Onion (for sets, ) in drills............30 bu. Onion Sets (small, in drills.......10 bu.

qts. Parsnip, in drills............... 5 lbs.

lbs. Peas, in drills............... 2 bu.

qts. " broadcast..............

lb. Potatoes (cut tubers)............10 bu.

lb. Pumpkins, in hills.............. 4 lbs.

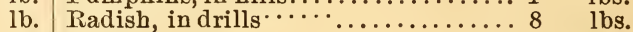

qts. Sage, in drills...................

qts. Salsify, in drills..................

bu. Spinach, in drills................. lbs.

bu. Squash (bush varieties, ) in hills....4 lo lbs.

lbs. " (running varieties,) in hills... 3 lbs.

lbs. Turnip, in drills................. $11 / 2$ lbs.

lbs. “ broadcast.............. 2 lbs.

lbs. Tomato (to transplant) .......... $1 / 4 \mathrm{lbs}$.

Quantity of Seed Required of a Given Number of Plants, Number of Hills or Length of Drill.

Asparagus ........... $1 \mathrm{oz}$. to $50 \mathrm{ft}$. drill

Beet.................. $\vec{I} \mathrm{oz}$, to $50 \mathrm{ft}$.

Carrot................ $1 \mathrm{oz}$. to $150 \mathrm{ft}$.

Endive............. $1 \mathrm{oz}$. to $150 \mathrm{ft}$.

Okra................ 1 oz. to $40 \mathrm{ft}$.

Onion .............. 1 oz. to $100 \mathrm{ft}$.

Onion sets, small....... 1 qt. to $20 \mathrm{ft}$.

Parsley............. $1 \mathrm{oz}$, to $150 \mathrm{ft}$.

Parsnip............... $1 \mathrm{oz}$. to $200 \mathrm{ft}$.

Radish ............. 1 oz. to $100 \mathrm{ft}$.

Salsify.............. $1 \mathrm{oz}$. to $70 \mathrm{ft}$.

Spinach............. 1 oz. to $100 \mathrm{ft}$.

Turnip.............. 1 oz. to $150 \mathrm{ft}$.

Peas................. 1 qt. to $100 \mathrm{ft}$.

Dwarf Beans........... 1 qt. to $100 \mathrm{ft}$.

Leek................ 1 oz. to $100 \mathrm{ft}$.
Pole Beans............ 1 qt. to $150 \mathrm{hills}$

Corn.................. 1 qt. to 200 "

Cucumber............... 1 oz. to 50 "

Water-Melon............ 1 oz. to 30 "

Musk-Melon............. 1 oz. to 60 "

Pumpkin............... 1 oz. to 40 "

Early Squash........... 1 oz. to 50 "

Marrow Squash.......... $1 \mathrm{oz}$ to 16 "

Cabbage................ 1 oz. 2000 plants

Cauliflower.................. 1 oz. 2000

Celery.................... 1 oz. 3000

Egg Plant.................. 1 oz. 1000

Lettuce.................. 1 oz. 3000

Pepper..................... 1 oz. 1000

Tomato................. 1 oz. 1500 


\section{J. M. PHILIPS \& SON'S}

\section{AnNual

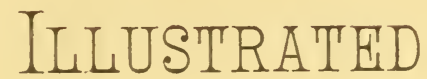 \\ Catalogue}

$-\mathrm{OF}-$

\section{Vegetable Garden Seed.s.}

Prices of Seeds in Packets-The seeds are mostly put into packets with price on them and are sold at Five and Ten cents each. If any are found without price on, sell at Five cents.

ASPARAGUS.

CONOVER'S COLOSSAL.

BEANS-Dwarf or Snap.

\section{GREEN SORTS.}

CULTURE-About the first of May select a warm, dry, sheltered spot; dig and manure slightly, make drills two inches deep and two feet apart; drop the Beans three inches apart in the drill, and cover not more than two inches deep. Keep hoed when not wet, and the weeds killed; and plant every two weeks for a succession of crops.

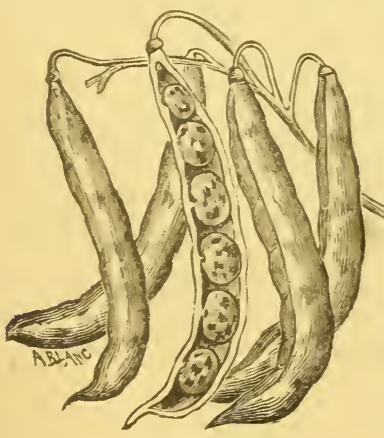

EARI,Y RED VALENTINE. der and succulent.
One of the very best snap shorts; having round, fleshy pods, which mature quick$1 y$ and remain a long time brittle and tender. Ear 1 y and very productive.

Early $R$ ed Valentine, ear1y and productive; pods ten-
Early Six Weeks, (Round Seeded) a small, round, oval bean; color, dark orange; dwarf growth ; quite early and a good bearer; used mostly in the pods.

Early Six Weeks, (Long seeded) hardy and prolific; seeds pale yellowish drab, with an olive-green line about the eye.

Early Mohawk, one of the hardiest and most productive of the dwarf varieties; seeds variegated with drab, purple and brown.

Early Rachel, vines large, spreading, productive, with coarse leaves and purple blossom; podslong, straight, narrow ; beans long, kidney shaped, brown, with dash of white on one end.

Early Red Eyed China, very early and of fine quality; seeds white, colored and spotted about tlre eye with purplish red.

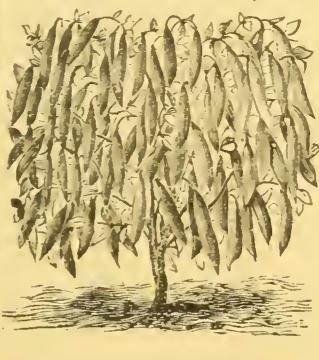

This variety, for field culture, is very prolific; it is what its name indicates, a Tree Bean; grows to the height of eighteen to twenty inches, branching out in all directions, bearing its pods so high that they do not touch the grouud, enabling it PROLIFIC TREE; BEAN. to stand a wet spell 
without injury to the crop. All know who have raised beans, that where the pod lies in contact with the ground after ripening, a very little rain ruins the crop, turning the pods and beans black. One plant known to bear 399 full sized pods in Ohio. The seed, which is pure white, somewhat resembles the common Navy Bean, but is more rounded at the ends.

Refugee, or Thousand to One; hardy, yields abundantly, and of fine quality; as a String Bean, or for pickling, it is considered the best; seeds drab, with numerous spots and patches of purple.

Large White Kidney, or Royal Dwarf; as a shell Bean, green or ripe, this is one of the best of the Dwarfs; the seeds are of large size, pure white, tender and delicate.

Large White Marrow, vines large, slender, spreading, with short runners, small leaves and small white blossoms; very prolific ; pods medium, broad, green, changing to yellow; beans large, clear white.

\section{WAX SORTS.}

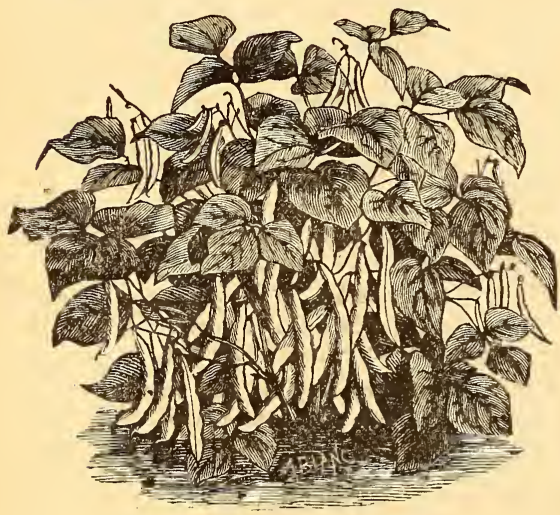

DWARF MONT D'OR BEAN.

The earliest of the dwarf wax sorts, and a variety less liable to rust than any other. It is unusually prolific; at times over twenty pods four to five inches long can be counted on a single plant. Has golden yellow pods of tender and most excellent flavor. Market gardeners particularly will find it a most profitable sort to grow on account of its extreme earliness, beautiful pods, and vigorous growth.

Early Black Wax, a variety of great merit, highly recommended as a String Bean; pods transparent, waxy yellow, thick and very tender.

New Early Golden Wax; the very best dwarf bean known. The pods are large, long, brittle, entirely stringless, and of a rich, golden, wax color.
Early White Wax; a variety similar in every respect to the "Black Wax," except in color which is pure white.

Crystal White Wax, a distinct white seeded variety, with waxy, transparent pods. It is stringless, crisp, tender, and of the richest flavor. The pods, though quick to develop, are slow to harden-retain their tenderness on the bush longer than any other sort.

\section{BEANS-Pole or Running.}

CULTURE-If warm, dry weather, plant about the middle of May, for an early crop, and about the first of June plant Limas and the other sorts for the principal crop. Plant in hills, about four feet apart, two inches deep. Manure freely.

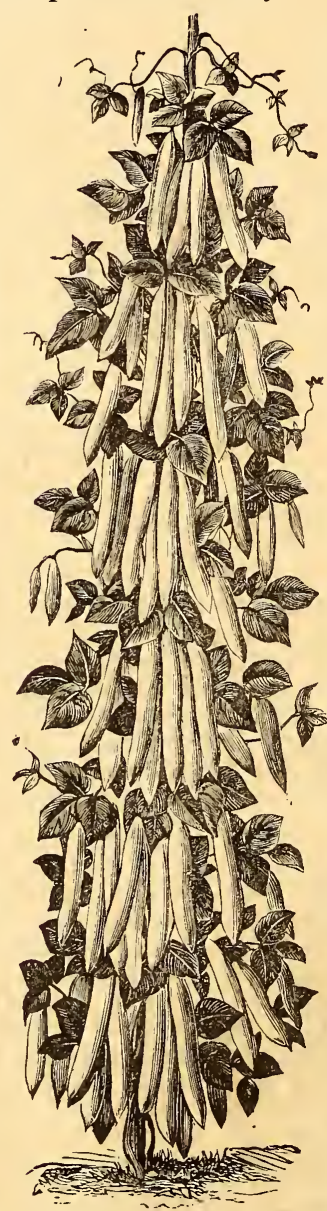

New Golden Wax Flageolet Pole BeanThis new and prolific Golden Wax Pole Bean, which presents a magnificent sight, in growth, the vines being crowded with bunches of the long, handsome pods. The pods are $7^{1 / 2}$ to Io inches long, of a rich, golden-ye11 ow color ; round, full and fleshy; entively free from strings and of superb quality. Thevines, while quite young, produce the pods in great abundance near the ground, as early as any dwarf wax bean, and searlier than any other pole bean. The vines continue to grow and bear profusely the entive season. In fine quality, extreme earliness and everbearing character this new Pole Bean is unique, and cannot be too highly recommended.

Early Dutch Case Knife; this is one of the earliest and most prolific sorts, having long, flat pods with white seeds, which are good green or dry. 
Horticultural Cranberry, or Wren's Egg ; pods striped with red, seeds oval, of medium size. Used both in the por and shelled; very productive, and good dry.

\section{BEANS-Pole or Running.}

Large White Lima; a large, late bean, with broad, rough pods ; seeds, white, broad, and rather full. It is surpassed by no other variety, and is a general favorite wherever it can be cultivated.

German Wax (Black seeded;) pods of a fine, waxen, semi-transparent white color; crisp tender and succulent, and continuing so, longer than most other sorts.

Giant Wax (Red seeds;) pods from six to nine inches long, thick and fleshy-yellow color and waxy appearance, perfectly tender and may be used as a snap bean.

Scarlet Runner; this variety grows fifteen feet high, has flowers of brilliant scarlet, and is generally cultivated as an ornamental climber.

White Runner; like the Scarlet, except in the color of the seeds and flowers, which are pure white.

Southern Prolific; the most prolific sort in cultivation, and very popular at the south for snaps. Vines vigorous, with large, thin, smooth leaves ; blossoms white, growing in fours ; pods green, nearly round, very long, fleshy, crisp and excellent; beans small, oval, dun colored, veined.

\section{BEET.}

CULTURE-Sow in well enriched ground, in drills, from April to June: thin out the plants to stand six inches apart.

The Egyptian Beet is without a doubt the earliest kind yet known, and is highly esteemed by our best gardeners as a first early, being a dark red in flesh; a week earlier than Bassano.

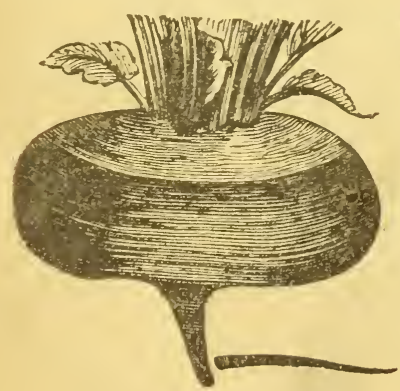

Early Dark Red Egyptian; a new, early and superior variety, quite distinct, very deep red, tender and delicious; in form like the Flat dutch Turnip; ten days earlier than any other; a most DARK RED EGYPTIAN.

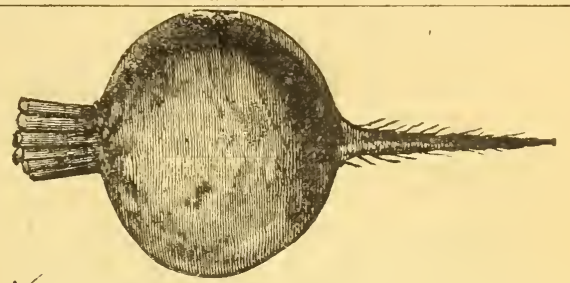

$\checkmark$ Early Eclipse-An improved extra early sort. Tops small, dark red shading to green on outside of the leaves. Roots nearly round with a lighter red, very sweet, crisp and tender, especially when young. One of the most desirable sorts for bunching.

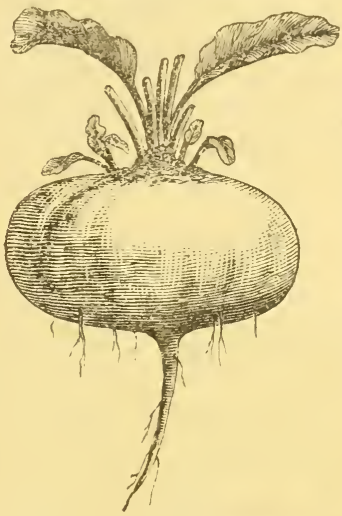

Early Turnip Bassano; roots flat, turnip-sh aped; flesh white, circled with rose color. A few days later than $\mathrm{the}$ Egyptian; grows to a good size on light soil, very tender and juicy.

EARLY TURNIP BASSANO.

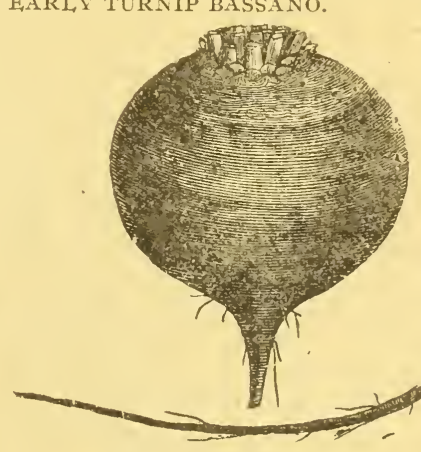

Dark Red Turnip; the stand ard early sort. Blood-red, t u r n i p$\mathrm{s}$ h a $\mathrm{p}$ ed, with small to p, t a proot; very $\mathrm{t}$ e $\mathrm{nd}$ e $\mathrm{r}$, and good for e a r $1 y$ us a nd late keepDARK RED TURNIP.

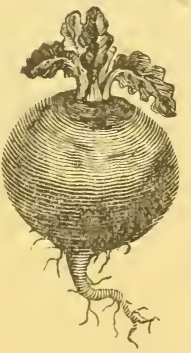

Dewing's Improved Blood Turnip-Fine turnip form, very symmetrical in shape, and free from any fibrous roots. Flesh deep blood-red, very tender and sweet; grows uniformly to a good size. Excellent for table. Early, and when sown late, desirable for winter.

DEWING'S IMPROVED BLOOD TURNIP. 
Dark Long Red-The best strain of long, dark red beet in the market and Especially Desirable for winter or Fall Use.

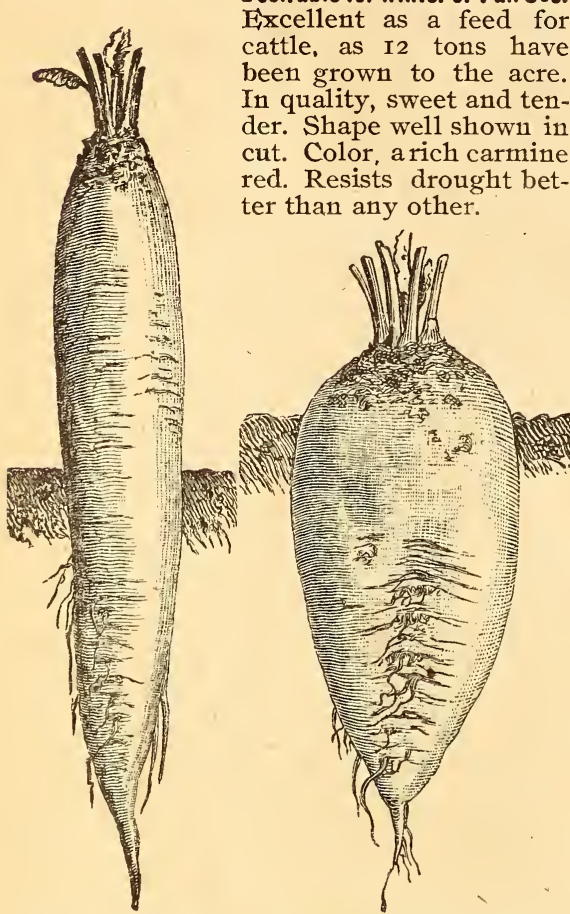

DARK LONG RED.

FRENCH WHITE SUGAR.

French White Sugar; this grows to large size, much above ground; roots medium length, white ; leaves green ; considerably grown in this country for feeding. Cultivated extensively/for manufacture of sugar.

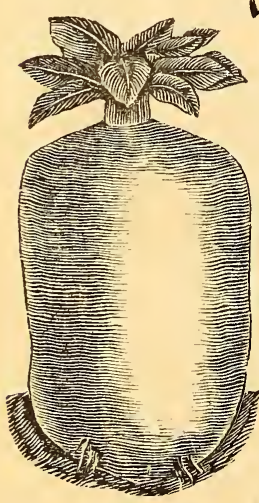

Golden Tankard Mangel Wurze ITops comparatively small, w ith ye 11 ow stems and $\mathrm{midribs}$; neck very small; roots large, ovoid, but filled out at top and bottom, so as to approach a cylindrical form. Flesh yellow, zoned with white. A great inprovement and worthy of trial on every farm.

$\sqrt{\text { Mammoth Long }}$ Red (Mangel Wurzel;) a new variety, producing roots of mammoth GOLDEN TANK- size, very regular and ARD. with a small top.
BROCCOLI.

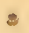

The Broccoli is closely allied to the Cauliflower family. They require similar cultivation and treatment to Cauliflower.

Early Purple Cape; this is the most valuable kind for the North.

\section{BORECOLE OR KALE.}

CULTURE-The plan is to sow in rows, about a foot apart, in September, and gather in early spring, like spinach.

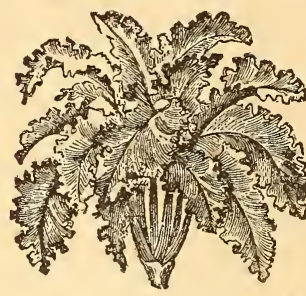

Dwarf German Kale, German Greens or Sprouts - (Dwarf Curled Scotch Kale.) This is more hardy than Cabbage, and makes excellent greens for winter and spring use. The leaves are curly, bright green, BORECOLE, OR KALE. very tender and delicate in flavor. Sow seed in May or June; transplant in July, and cultivate same as Cabbage. For early spring use, sow in September; protect over winter with a covering of straw or litter, and treat like spinach.

Brussels Sprouts-Th1s is a delicious vegetable, well worthy of general cultivation. The plant grows about two to two and a half feet high, and, as shown in the illustration, produces from the stem numerous little sprouts, one to two inches in diameter, resembling cabbages in miniature. The sprouts are used as greens,

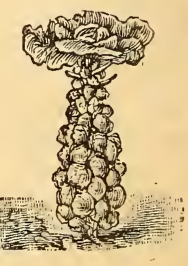

SPROUTS. and become very tender and of rich flavor when touched by frost. Sow in May, and treat in the same manner as Winter Cabbages.

\section{CABBAGE.}

There is no vegetable which is more universally cultivated than this. It is found in the poorest and smallest garden and it responds so readily to better care, that it claims a place in the finest garden, and the attention of the most skillful gardener.

CULTURE-Sow the early sorts in Autumn, and protect by a cold-frame during the winter, transplanting early in Spring, or in hotbeds during February and March, and transplant middle of April; or sow the seed in open ground, as early in the Spring as the ground can be worked. Sow for late crop in April and May. They should be sown in 
shallow drills, four to six inches apart. When the plants are six inches high transplant into richly manured ground, the early kinds two feet apart; the later kinds, for winter use, three feet apart. The ground must be deeply loosened and worked thoroughly to grow large and good heads. Hoe often, to kill weeds, and draw some earth up to the stems.

\section{EARLY VARIETIES.}

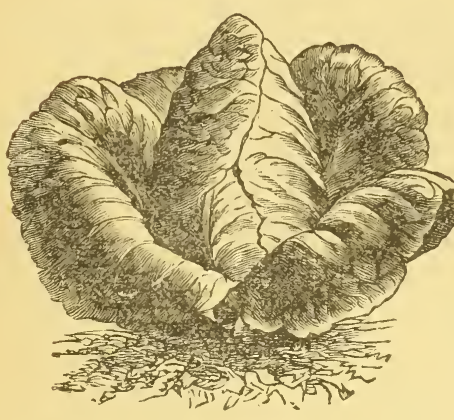

EXTRA FARIY ETAMPES.

Extra Early Etampes-It is about ten days earlier $\mathrm{t} h$ a $n$ any other cabb a g e ; $\mathrm{t} h \mathrm{e}$ he a d s are ob$10 \mathrm{n} \mathrm{g}$, rounded at the top, very solid and firm, while it seldom fails to head. The heads are of medium size, and of very fine quality.

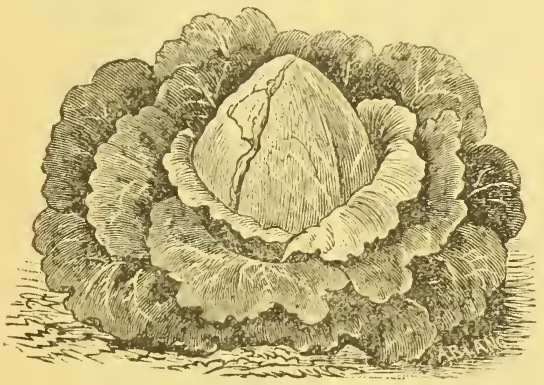

I,ITTTLE PIXIE.

Little Pixie; remarkable for its earliness, its diminutive size and dwarfish character. It is tender in texture, and the flavor mild and delicate.

Early York ; a very valuable early variety. $\mathrm{He}$ a ds $\mathrm{sm}$ a 11 , rather heart-shaped, firm and tender; of very dwarf growth, and may be transplanted I5 or IS inches apart.

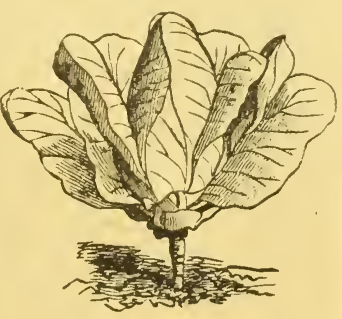

EARI, YORK.

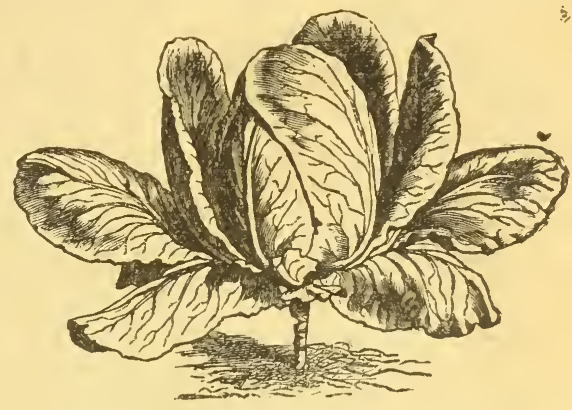

EARLY LARGE IORK.

Early Large York; succeeds the Early York, and is equaily desirable. It is of larger size, ahout ten days later, more roburst, and bears the heat better.

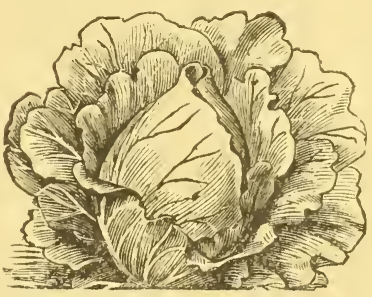

aㅏly Jersey Wakefield; heads of medium size, generally somewhat conical, but sol1etimes round, and rery com pact. I fine, early variety, heading readi$1 y$, and a great favorite with

EARLY JERSEY Eastern market

WAKEFIELD. gardeners.

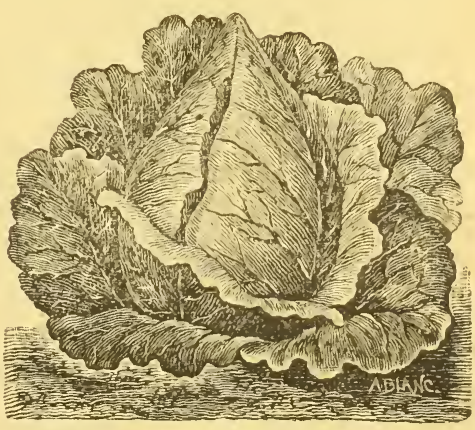

EARLY WININGSTADT CABBAGE.

Early Winningstadt-A well known and very popular early variety, in season very close to the Wakefield; heads large, decidedly conical, leaves bright, glossy green; heads solid and hard, even in summer. This is a very sure-heading variety, valuable not only for early use, but also for winter cabbage. 


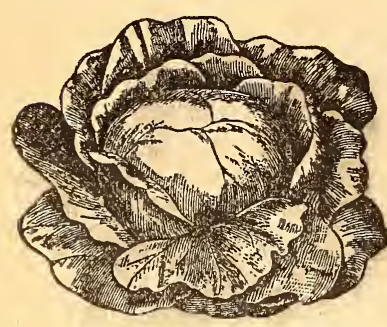

Early flat $\mathrm{D} \mathbf{u} \mathbf{c} \mathbf{h}$; heads medium size, solid, flat on the to $\mathrm{p}$; grows low on the stump, and is of good flavor.

EARLY FLAT DUTCH.

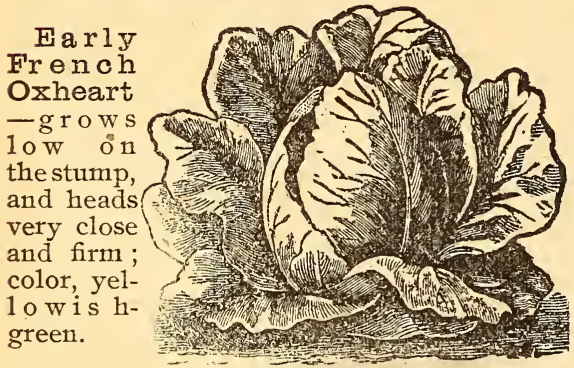

LARGE FIENCII OXHFART.

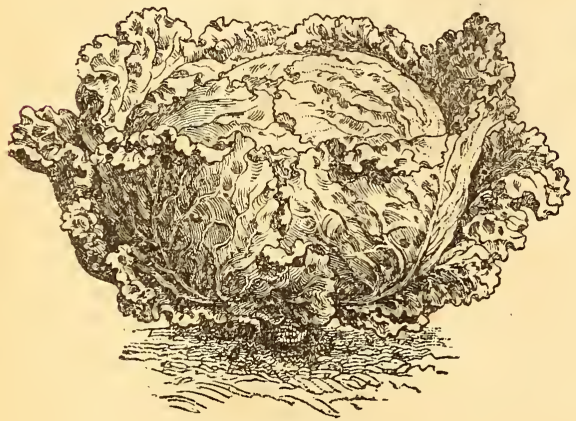

SCHWEINFURT

Early Schweinfurt; It is the largest and latest of all the Early Cabbages. The heads are tolerably solid, and the quality excellent.

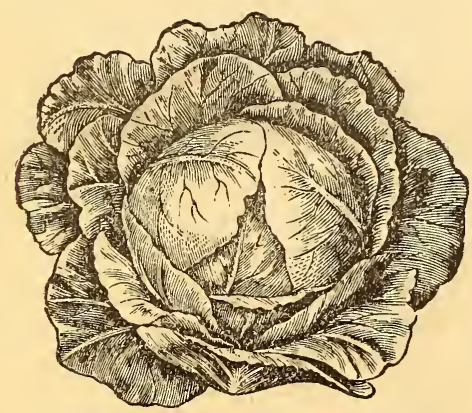

HENDERSON"S EARLY SUMMER.
Henderson's Early Summer-Heads about ten days later than the Jersey Wakefield, but being of over double the size, it may be classed as the best large early Cabbage. In weight it is equal to most of the late varieties, and its short outer leaves enable it to be planted as close as the Jersey Wakefield, about 12,000 to the acre, while the Early Flat Duch, Winntngstadt, etc., producing no larger heads, can only be grown at the rate of 8,000 to the acre.

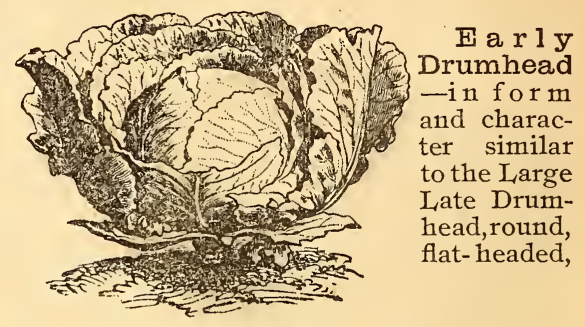

EARLY DRUMHEAD.

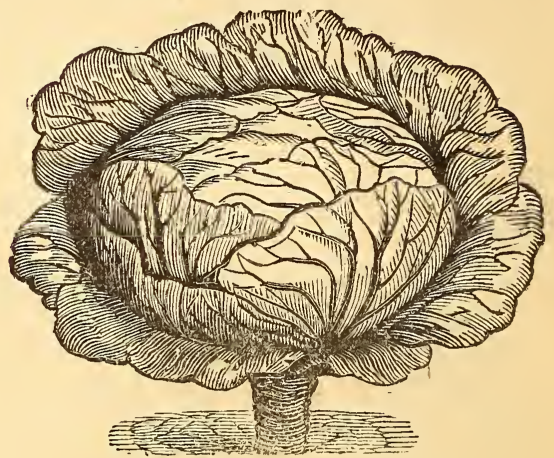

PREMIUM FLAT DUTCH.

Premium Flat Dutch; as a variety for the Winter market it has no superior, and is more extensively grown than any other. It possesses all the good qualities of the Late Flat Dutch, and is a sure header. With good cultivation, on moist ground, ninetyfive in a hundred will head up hard and fine.

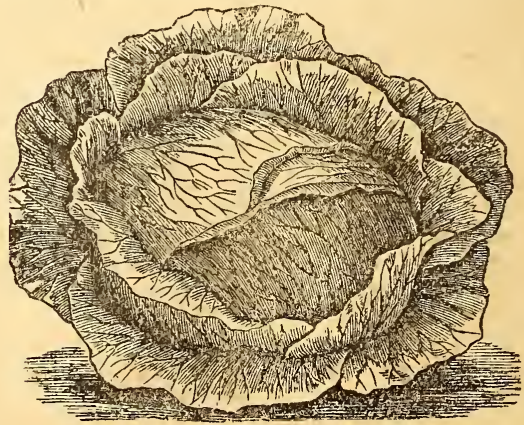

FOTLER'S IMPROVED BRUNSWICK. 
Fotler's Improved Brunswick; the best early Drumhead variety in the market, produces a good, firm and solid head, often weighing from 15 to 20 pounds.

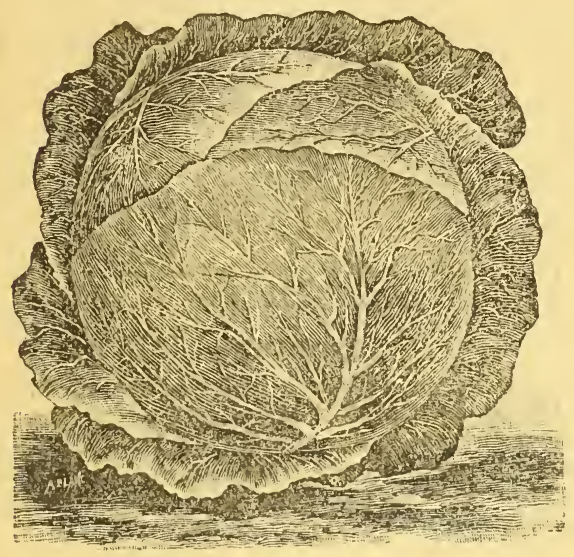

SURE-IIEAD.

Sure-Head-This popularcabbage is rightly named, Sure-Head, and never fails to make a fine, solid, large head, with few outer leảes. It is a strong, vigorous grower, ripening late; uniform in size and color.

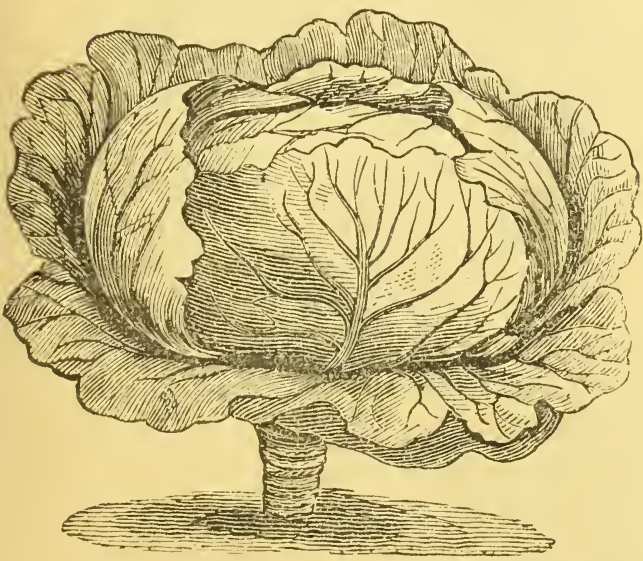

MARBLEHEAD MAMMOTH DRUMHEAD.

Mammoth Drumbead-This is without doubt, the largest variety of the Cabbage family in the world. I have grown them weighing 24 pounds; single specimens have been grown to weigh 60 pounds. Quality very tender, sweet and excellent.

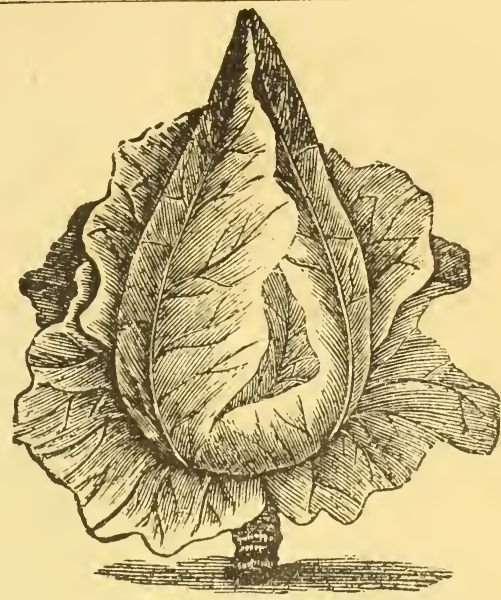

FILDERKRAUT.

Filderkraut; a German variety, which has proven in this country to be one of the most valuable sorts. It is equally good for early or late use, and heads up hard, with few side leaves. This variety is largely used in Germany, in the manufacture of "Kraut"

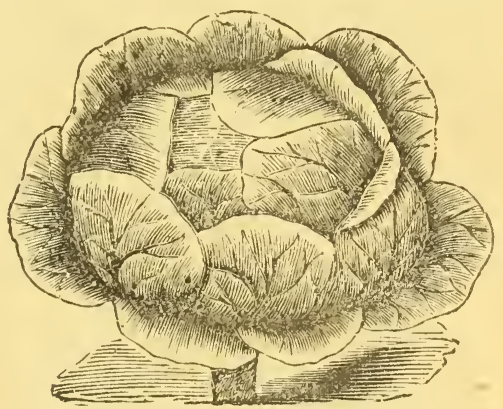

STONE MASON.

(Originated with J. Stone, of Marblehead, Mass.)

Stone Mason; an improved variety of the Drumhead; head flat and solid, stem short and small, quality sweet, tender and rich; a profitable market variety.

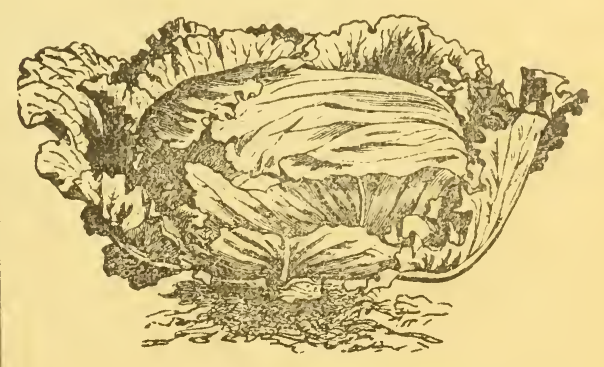

LARGE LATE DRUMIIEAD. 
Large Late Drumhead; this is a large Fall and winter variety, with broad, flat, or round heads; very compact and of a lightish green.

Large Bergen, or Great American; one of the largest and latest sorts, of a light green color, with a short stem; the heads are large, firm, very tender, and of most excellent flavor.

Red Dutch, or Pickling; dark red or purple color.

Early Dwarf Ulm Sayoy; one of the earliest and sweetest of the Savoys. Heads, round, solid ; leaves, small, thick, fleshy, of fine, deep green color, and of most excellent quality.

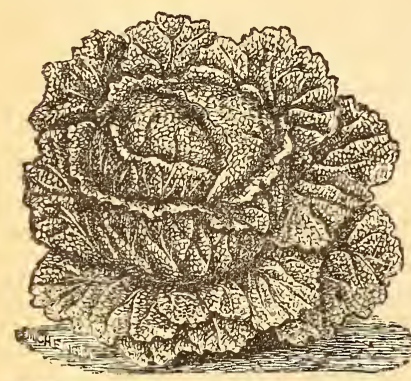

IMPROVED AMERICAN

SAVOY.

Improyed American Savoy - C1 o s e 1 y approaching $t h e$ cauliflo w e $r$ in delicacy and de 1 icious flavor. The best of all the Savoys for $\mathrm{g}$ e $\mathrm{n}$ e $\mathrm{r}$ a 1 market or home use. It has a short stump, grows to a large size, is compact and solid, and is a sure header.

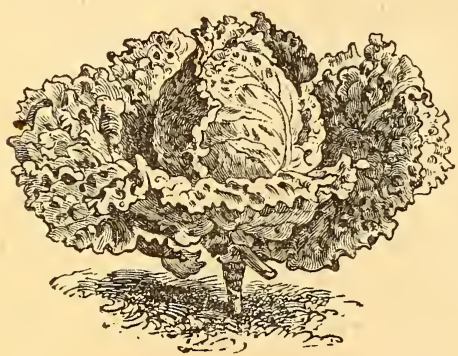

EARLY NETTED PARIS SAVOY.

Early Netted Paris Savoy; the peculiar characteristics of this fine variety are - very early, crimpled and netted to an unusual degree, and it also forms a compact, solid head.

Late Drumhead Sayoy; very tender and excellent for Winter. The Savoys approach nearer to the delicious richness of the Cauliflower than any of the other Cabbages; sow early.

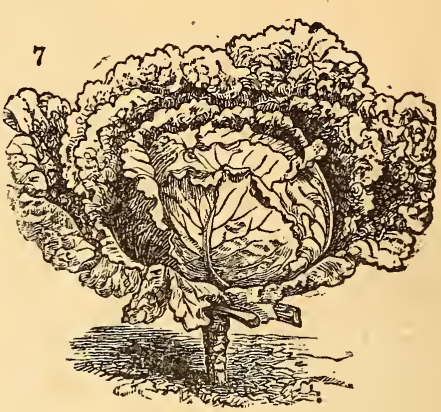

LATE DRUMHEAD SAVOY.

\section{CARROT.}

CULTURE.- Sow as early as the ground can be worked for early crop; for main crop sow from the middle of May till the last of june. Rows io inches apart; 7 to 8 inches in the row. Soil, light, sandy loam, richly manured and deeply dug.
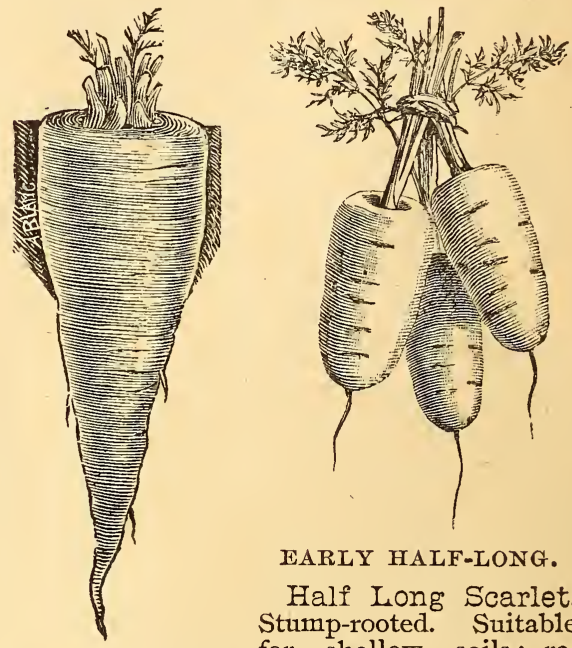

EARLY HALF-LONG.

Half Long Scarlet, Stump-rooted. Suitable for shallow soils; reIMPROVED LONG markably smooth in skin, ORANGE. rich in color, and of uniform texture.

Improved Long Orange-A well known standard sort. Roots long, thickness near the crown, tapering regularly to a point; color deep orange; suitable for the table and main field crop. It requires a deep soil, and the plants should stand eight inches apart, in eigh teen inch drills, for the roots to attain their full size.

\section{CAULIFLOWER.}

CULTURE-For the spring and summer crop; sow the early varieties about the last of winter, in a hot-bed, and transplant into the open air 
as soon as the ground can be worked. For the late, autumn crop, sow the late kinds about the middle of spring, and transplant like winter Cabbage. In dry weather, water freely, and as they advance in growth, hoe deep, and draw earth to the stems. After they begin to head, they should be watered every other day, and the leaves gathered and pinned together over the heads to protect them from the sun and keep them white.

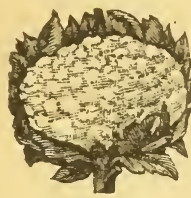

Early Snowball-Hig h ly esteemed by market gardeners for its earliness and reliability as a sure header. Tested with several other varieties, it has proven to be as early, if not earlier than any other sort. Its hardiness, sure heading and EARLY SYOW- compact growth, make it one BALL. of the best for forcing or wintering over

Extra Early Paris - Heads large, white, compact and solid; of excellent flavor, tender and delicioús. Leaves large, stalk short. Be. ing so early, it must always be a favorite, especially with market gardeners.

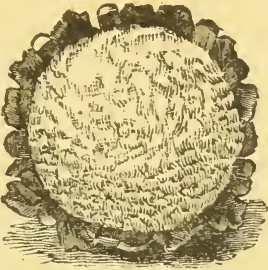

EXTRA EARLY PARIS.

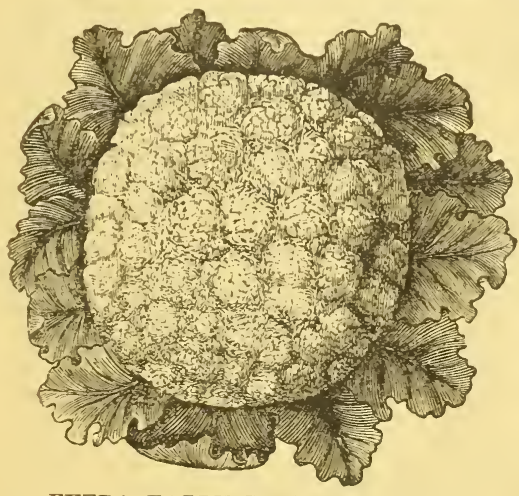

EXTRA EARLY DWARF ERFURT.

Extra Early Dwarf Erfurt-An extra early variety, much prized in Germany for early market use. Scarcely a plant fails to produce a good head. It is of dwarf habit, compact growth, short outside leaves, and can be planted twenty inches apart each way. The best for early market and family use, and we think can be entirely relied upon, as the seed is selected with extra care, by one of the most careful growers in Germany.

Lenormand's Short Stemmed-A large late variety, with well formed heads of superior quality. Considered by the French one of the very best sorts. Plant hardy, semi.dwarf, pro. ducing many leaves which protect the close, solid curd, keeping it well protected by leaves, hardy and stands dry weather.

\section{CELERY.}

Cultivation-Plant seeds in hot-bed or very early in open ground. Set the plants 6 to 12 inches apart in a row, the rows 4 to 6 feet apart, trenches 1 foot deep and well manured. To blanch, draw earth around the plants from time to time, taking care not to cover the tops of the centre shoots.

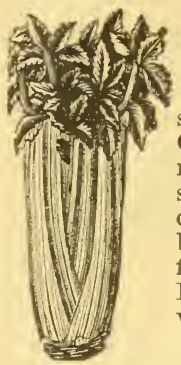

Large White Solid-The best strain of Large White Solid Celery, and a most imposing variety. It attains a very large size, is of quick growth, stiff, close habit, remarkably solid, bianches perfectly white, of fine flavor, crisp, and very tender. It is a very show $y$ and handsome variety for market.

LARGE WHITE SOLID.

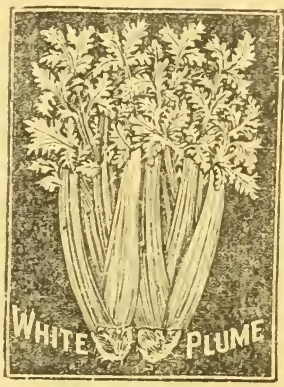

White PlumeThis new Celery is valued because, naturally, the stalks and portions of its inner leaves and heart are white. By simply tying up the stalks and drawing up the soil with the hoe, the work of blanching is complete. It is ornamental, tender, crisp and of good flavor, and very early.

WHITE PLUME.

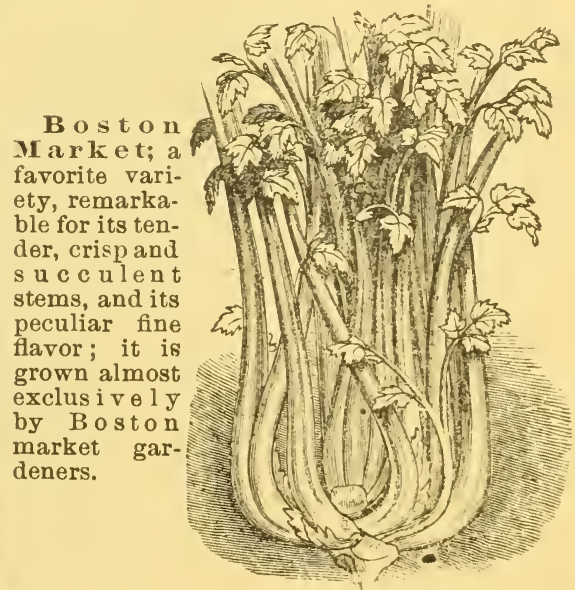

BOSTON MARKET. 


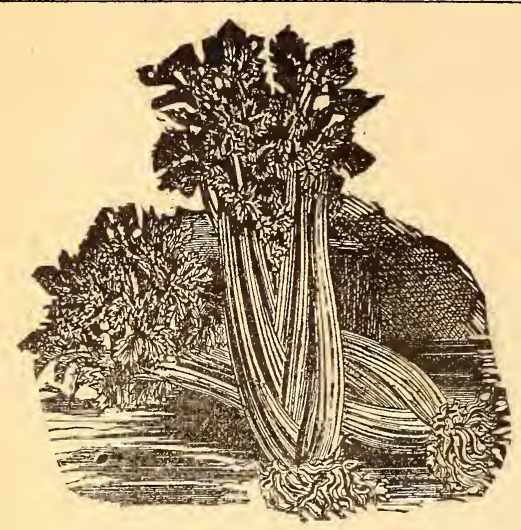

DWARF LARGE-RIBBED WHITE SOLID.

Dwarf Iarge-Ribbed White Solid; a large size; vigorous growing variety; stalks white, round, very crisp, perfectly solid and of superior flavor; this Celery has no superior and is the best in caltivation of the dwarf varieties.

Henderson's Rose-Very solid and an excellent keeper. The red varieties of Celery are generally better flavored than the white.

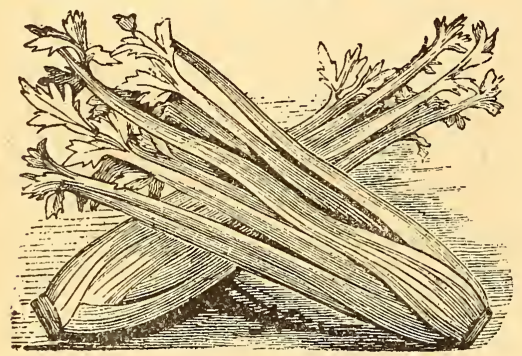

HENDERSON'S ROSE.

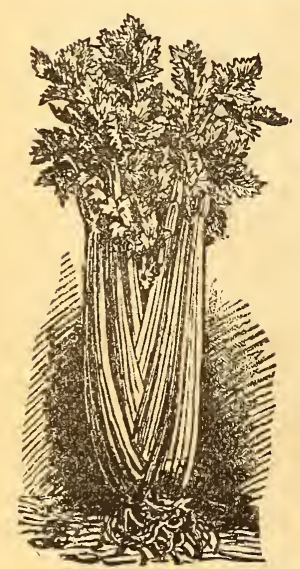

Dw arf Golden Heart-A very popular and distinct variety. In habit of growth it resembles the Half Dwarf White sorts, except that when blanched the heart, which is large and full, is of a waxy, golden yellow. It is a most striking and showy variety, for either market or private use. It is entirely solid, of most excellent flavor, and keeps well during the winter.

DWARF GOLDEN HEART.

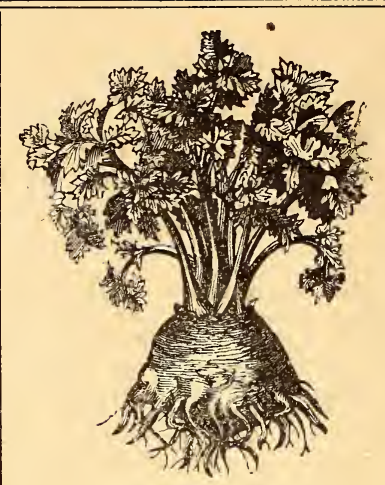

Turnip

R o o te d: turnip-shaped bulbs.

Ce 1 e r y Seed; for flavoring.
TURNIP ROOTED.

\section{CORN-Sweet.}

Culture-Plant in hills, 3 feet apart each way, and 3 to 4 grains in a hill; hoe often and draw soil up to the stems; break off side shoots. Make the ground rich with well-rotted manure.

Extra Farly Tom Thumb; New, very early. At least a week earlier than Minnesota, and sweetest of all the early varieties; ears of fair size, kernel large and white, resembling the Crosby and Evergreen in flavor; a most valuable sort for market gardening.

Early Marblehead Sweet; This (new) variety has proven to be the earliest in cultivation. It has been tested with the Early Minnesota, Narragansett, and other early sorts, and proved a week earlier than any of them. The stalk is of dwarf growth and ears set very low down; it is of fair market size and very sweet. Many gardeners who planted it last year, say it gave them the complete control of the early markets.

Early Minnesota; one of the earliest varieties of Sweet Corn in cultivation; the stalk is of dwarf habit, ears small, very productive, and of excellent quality.

Early Triumph Sweet; The largest of the early varieties; are large, productive, flavor rich and sweet; a fine market variety.

Moore's Early Concord.-Ears large, having from twelve to twenty rows on the ear; a superior variety, either for the market or family use, matures earlier than any other variety of equal size.

Stowell's Evergreen Sweet.-The best for the main crop and said to be the sweetest variety. One stalk will produce three to five ears, some of which will keep green till frost comes. Cob medium size, white ; kernels small, deep, frequently irregular in the rows. 


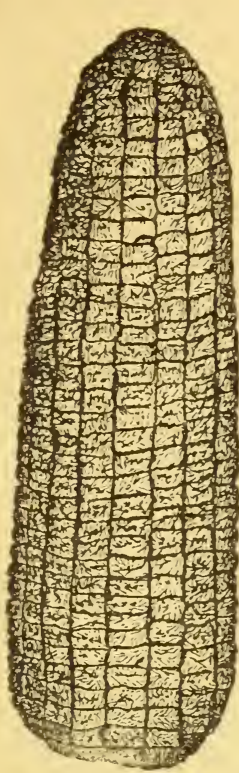

MAMMOTH SWEET.
Mammoth Sweet - (See cut.) The largest variety, and late; twelve to sixteen-rowed; cob white, large and well filled; very productive, and fine flavored.

Black Mexican.Although the ripe grain is black or bluish black, the corn when in condition for the tabie cooks remarbly white, and is surpassed by none in tenderness. This by many is considered the most desirable for family use of any of the second early sorts.

Eryptian Sweet.A variety noted for its productiven es $\mathrm{s}$ - the stalks having from two to four ears each-the large size of its ears, its sweetness and tenderness. It is peculiarly adapted for canning purposes, and the superiority of the canned green corn of this variety is noticeable.

Adam's Extra Early.-The hardiest and earliest variety for table use, and can be planted earlier than any other, but is not a sweet corn, white indented grains and short ear.

Rice for Parching.-A very handsome variety ; ears short; kernels long, pointed, and resemble rice; color white ; very prolific; used entirely for parching, for which purpose it has no superior.

\section{CRESS OR PEPPERGRASS.}

CuLture.-Sow early in Spring, very thick$1 y$, in shallow drills. The sowings should be repeated at short intervals, as it soon runs to seed.

Curled.-This small salad was formerly $\mathrm{m} \mathrm{u} \mathrm{ch}$ used with lettuce, to which its wa $\mathrm{rm}$ pungent taste makes a most agreeable addition.

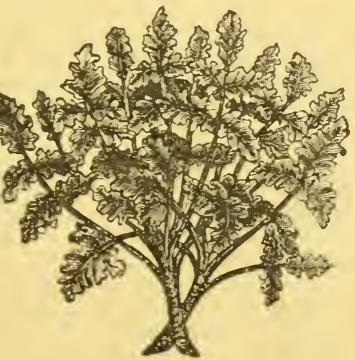

CRESS CURLED.

\section{CRESS, Water.}

Couture.-The plant is cultivated by sowing the seeds by the side of running water, near springs which are not severely frozen in winter, and the plants well covered with water duringithe winter.

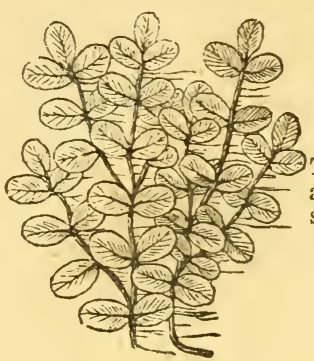

Water Cress.The leaves are used and eaten as an early salad in spring.
TRUE WATER.

\section{CUCUMBER.}

Plant when all danger of frost is over, in well prepared hills four feet apart each way. When all danger from insects is past, thin out to three or four plants in a hill. A shovelfull of manure mixed in the hill before planting will greatly increase the crop. The fruit should be picked frequently to keep the vines productive.

Early Russian.-The earliest in cultivation; It sets in pairs, and the first blossoms usually produce fruit; fiavor pleasant and agreeable.

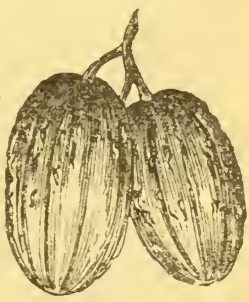

EARLX RUSSIA.N.

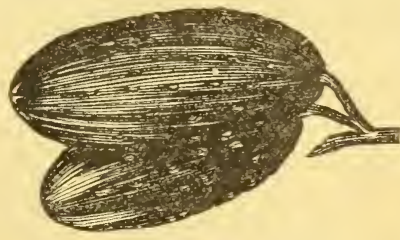

E a r 1 y Green Clus. ter.-A short, prickly variety, be a ring in clus. ters near the root; it is a great bearer, and comes to EARLY CLUSTER. maturity the earliest in the

list, excepting the Early Russian.

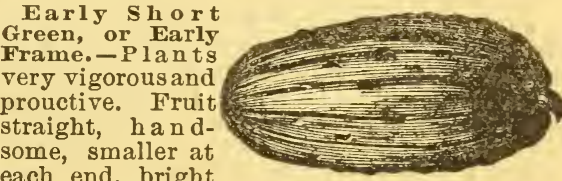
each end, bright green, lighter at the blossom end, with crisp, tender

EARLY SHORT GREEN OR EARLY FRANIE. flesh, and when young, makes excellent pickles. 


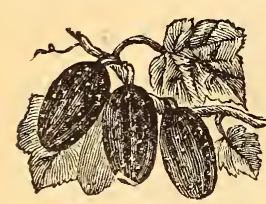

BOSTON PICKLING OR GREEN PROLIFIC.

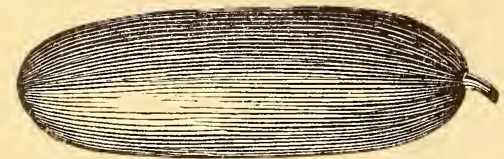

EARLY WHITE SPINE.

Early White Spine.-The best sort for the table ; the fruit, in turning white at maturity, retains its fresh appearance much longer than any of the yellow varieties; on this account it is a favorite with market men ; good for forcing and a great bearer.

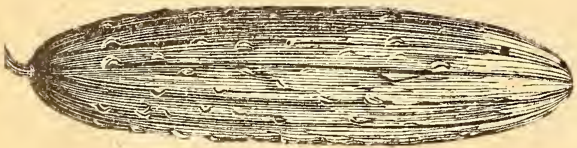

IMPROVED LONG GREEN.

Improved Long Green.-Produced by selection from the Long Green. Vines vigorous and productive, forming fruit fit for the table nearly as early as the shorter sorts ; fruit about twelve inches long, firm and crisp, with very few seeds. The young fruit makes one of the best of pickles, and when ripe is the best of any for sweet pickles.

Cherkin for Piekling.-A very small, oval shaped, prickly variety. It is grown exclusively for pickling; is the smallest of all the varieties, and should always be pickled when young and tender. The seed is slow to germinate.

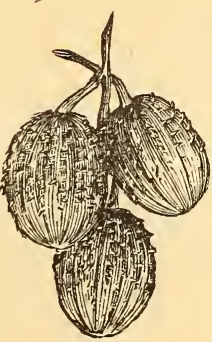

CHERKIN, OR BURR.

\section{EGG PLANT.}

CulTuRE.-The Egg Plant will thrive well in any good garden soil, but will repay good treatment. The seeds should be sown in hotbeds or warm green-house in March or April, and when about an inch high pot in two-inch pots. Plant out about June 1st, two and a half feet apart. If no hot-bed is at hand, they can be grown in any light room where the temperature will average 75 degrees.

Early Long Purple.-This is one of the earliest and most productive varieties ; fruit long, dark rich purple and of fine quality.

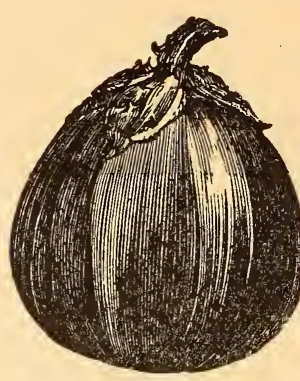

NEW YORK IMPROVED LARGE PURPLE.

\section{ENDIVE.}

This is a hardy vegetable, altivated principally for a winter salad. Sow from May until August for a succession of crops; tie the leaves loosely together to blanch them.

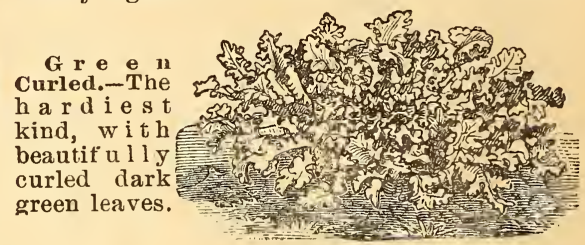

GREEN CURLED.

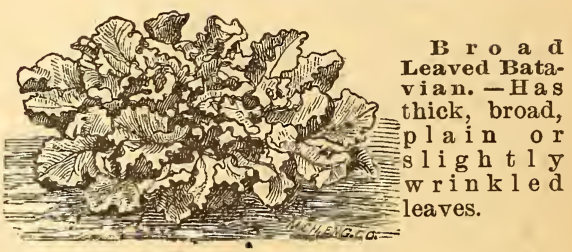

BROAD LEAVED BATAVIAN.

KOHL RAB!.

Culture,-The seeds may be sown at the same period as the Ruta Baga Turnip, and may be cultivated the same way.

Early White Vienna.-Dwart, early bulb white, h a ndsome, firm; leaves few and small.

Early Large Purple - Nearly identical with the last except in color, which is a bright purple, with the leaf stems tinged with purple.

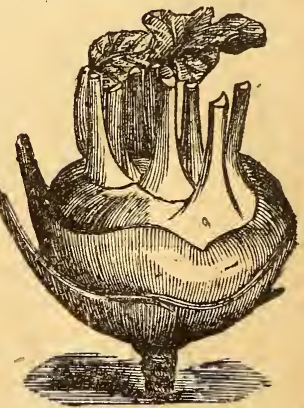

KOHL RABI. York ImprovPlants large, vigorwith light green oval, deep, out the stem ; flesh superior quality. ed Large Purple.cultivation, being leaves ; fruit very , 


\section{LEEK.}

The whole plant is eaten; used in soups, \&c.

Culture.-Sow very early in Spring, in drills, six inches apart and one inch deep. Thin out to one inch a part ; requires very rich soil ; water well if dry weather.

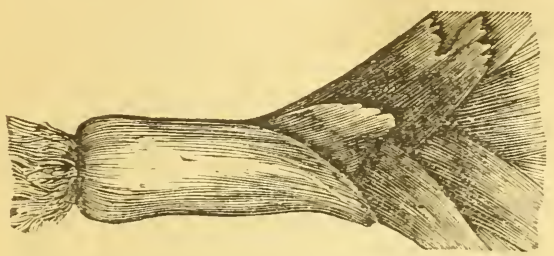

LONDOX FLAG.

Iondon Flag.-This variety is largely cultivated.

\section{LETTUCE.}

CULTURE.-Lettuce requires a very rich soil and every appliance the skillful cultivator can give, in order to obtain that crispness, juiciness and delicate flavor, for which they are so much esteemed. Several sowings are requisite during the season.

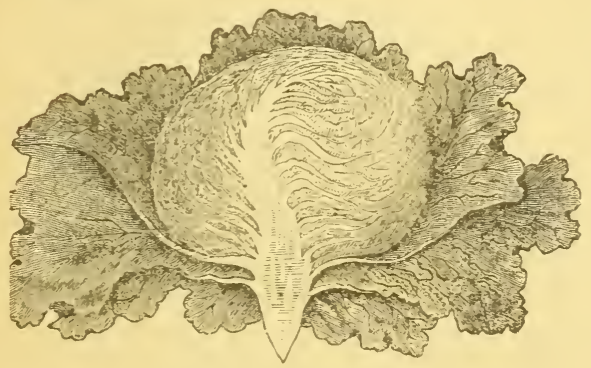

LARGE HAYSON.

Large Hanson.-Heads very large, solid, sometimes weighing two to three pounds; tender, crisp and of fine flavor; color beautiful green outside and white within. Stands the summer heat well ; and of the very best in cultivation.

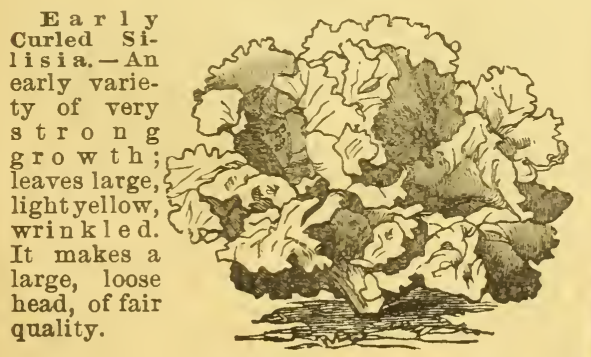

EARLY CURLED SILISIA.

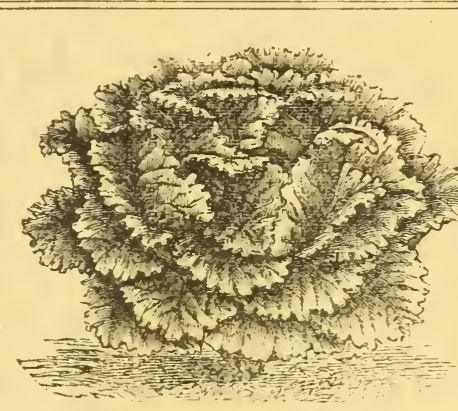

Early Curled Simpso $n$ -One of the best e a $\mathrm{r} 1 \mathrm{y}$ sorts for mark et or family use. $\mathrm{H}$ e a d s la $\mathrm{rg} \mathrm{e}$, 10 o $s$ e, all $\mathrm{t} \mathrm{he}$ leaves tending to p r o-

EARLY CURLED SIMPSOX. duce a head.

Tennis Ball BlackSeeded.- Well-formed heads, hardy and crisp; of excellent quality. One of the earliest of the heading varieties.

Tennis Ball, whitc seeded. Similar to the above, except in the color of the seed.

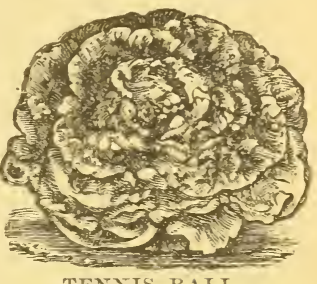

TENNIS BALL.

Boston Curled.-A variety of great beauty and of verv superior quality. The symmetry of its growth, and fine, elegant frilling of the leaves, render it highly ornamental.

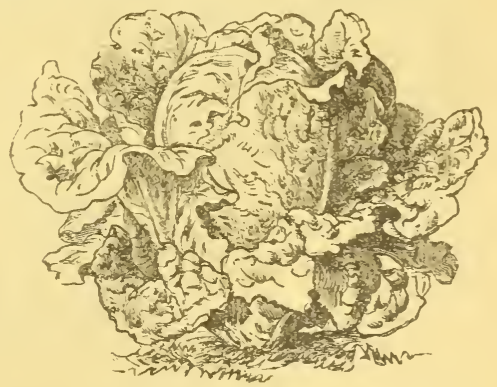

LARGE DRUIHEAD.

Large Drumlead.-Heads remarkahls large somewhat flattened, compact; pale green without, and white at the centre; crisp and tender; one of the finest summer varieties; seeds white.

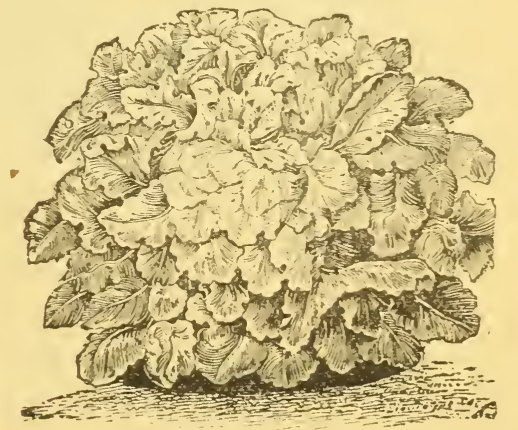


New Perpetual. - For tamily use this is one of the best lettuce, forming large, compact bushes, the leaves curling outward from the top, extra quality, being crisp, rich and tender, remaining fit to eat, and of the choicest quality, from 176 to 215 days, from one planting.

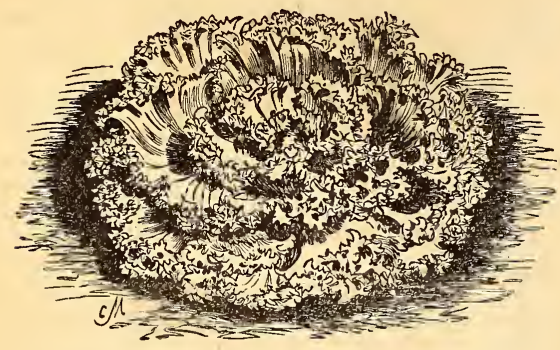

CALIFORNIA CURLED, OR GREEN FRINGED.

Green-Fringed. $-A$ very ornamental and most beautiful variety. Of a very delicate and peculiar shade of green, with the inner part of the leaves white. The edges are beautifully cut and fringed, being entirely distinct. The leaves are not only teuder and of good quality, but also highly ornamental on the table.

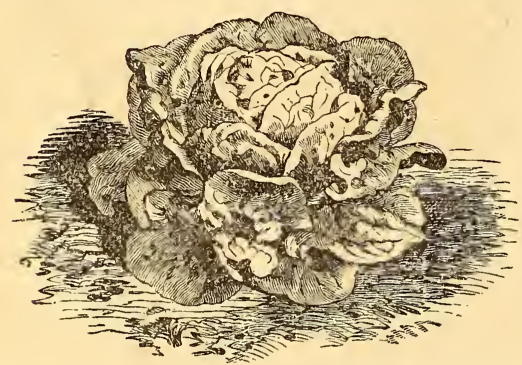

HARDY GREEN WINTER, OR HAMMERSMITH.

Hardy Green Winter.-One of the best winter varieties; very hardy and forms a solid head. The best for autumn sowing.

\section{MARTYNIA.}

Culture.-Sow in May, in the open ground, about three feet each way, where the plants are to remain, leave but one plant in a hill.

Proboscidea.-A hardy, annual plant, with curious shaped seed pods, which, when young and tender, are highly prized by many for pickling.

\section{MELON-Musk.}

CoLtukE.-Plant late in Spring, in hills five or six feet each way, well manured with old, rotten compost. A light, dry, sandy soil and a dry atmosphere are most suitable.
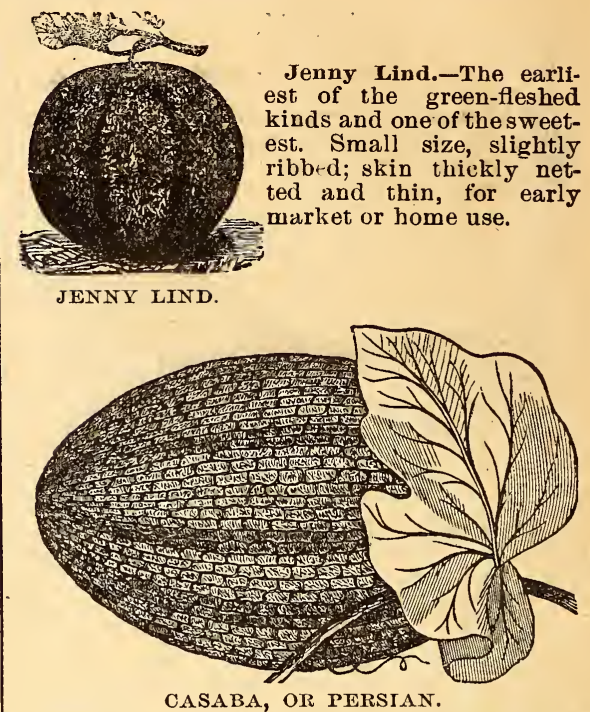

Casaba.-One of the largest and best Musk Melons in cultivation. Its usial weight, when well grown, is from tw+lre ! firteen pounds. Flesh, green, very sweet, melting and delicious.

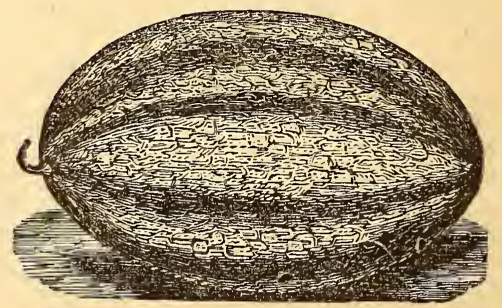

LARGE YELLOW CANTELOPE.

Large Yellow Cantelope.-A good sized variety, deeply ribbed; flesh salmon-colored; thick and musk-flavored. Earlier than the green sorts.

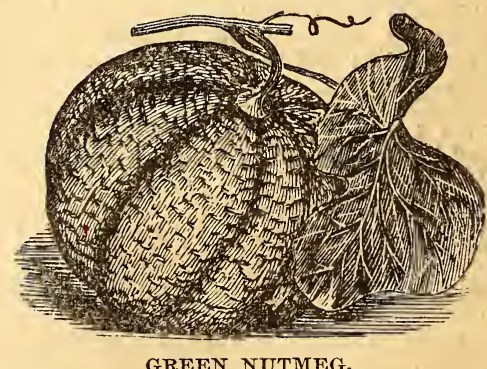

Green Nutmeg.-It is justly regarded as the ne plus ultra of its species. It is of large size, thickly netted, and deeply ribbed ; flesh, deep green, rich, sweet, melting, and of delicious flavor. 


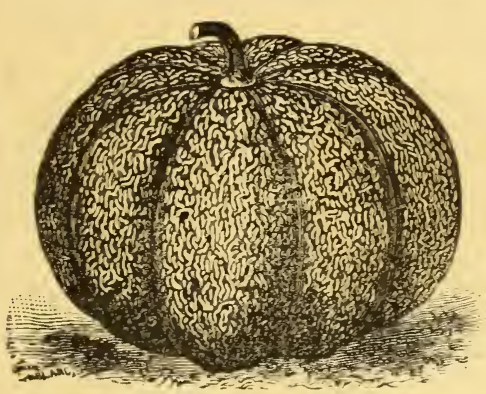

MONTREAL MARKET.

Montreal Market.-In size this exceeds all the nutmeg varieties, weighing sometimes thirty pounds. Very uniform in shape; netted, flesh green; quality remarkably good.

Two PRIZE MIELONS.-The largest melon was raised by J. B. Dabney, Esq., of Savannah, Iowa, and weighed $39 \frac{1}{2}$ pounds; the second largest was raised by J. WV. Scott, Esq., Socorro, New Mexico, weight 381/2 pounds. These are doubtless the largest Musk Mielons ever raised.

\section{MELON, Water.}

The Water Melon is a tropical fruit, and can be produced to perfection only on warm, light soil; and under a bright, hot sun.

CULTURE.-Although the finest melons are produced on light, sandy, comparatively poor soil, a vigorous start for the young plant is necessary, and for this we need a hill of rich earth, similar to that for cucumbers. If very large fruit is desired, pick off all but a few melons.

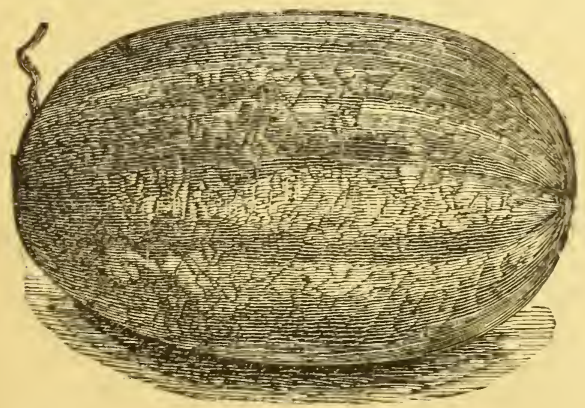

PHINNEY.

Phinney.-A very early variety; medium and uniform size and of beautiful form. Flesh light red; very sweet and delicious. For an early melon for family use it has few superiors.

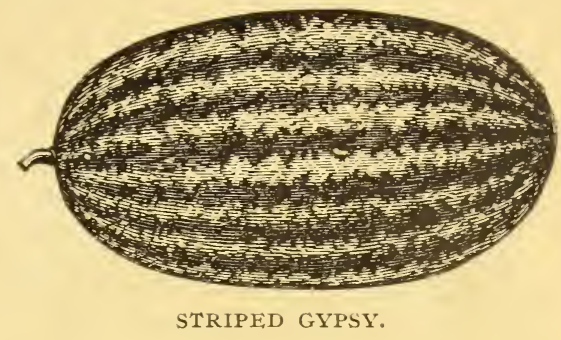

Striped Gypsy.-The largest of all the varieties of water melon, long, smooth, distinctly striped with light mottled and dark green, regular stripes. Flesh, bright scarlet, very solid; seeds white; one of the best market varieties.

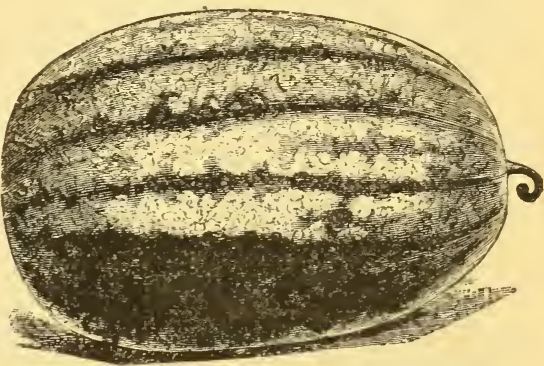

CUBAN QUEEN.

Cuban Queen.-One of the largest melons known, specimens having been grown that weigh 82 pounds. Vines vigorous; skin striped light and dark green. Flesh bright red, solid, very crisp and sugary.

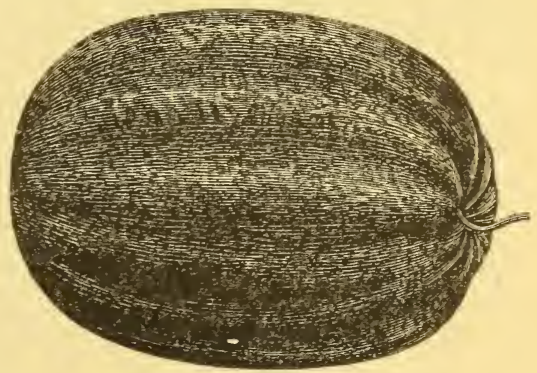

FERRY'S PEERLESS.

Ferry's Peerless.-This is unquestionably the best water melon in cultivation. Of medium size, thin rind, light mottled green; flesh, bright scarlet, solid to the centre, crisp, melting, and sweet as honey. 


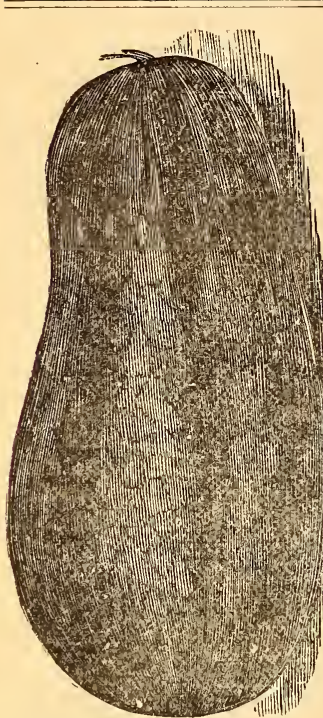

MOUNTAIN SWEET, OR MOUNTAIN SPROUT.

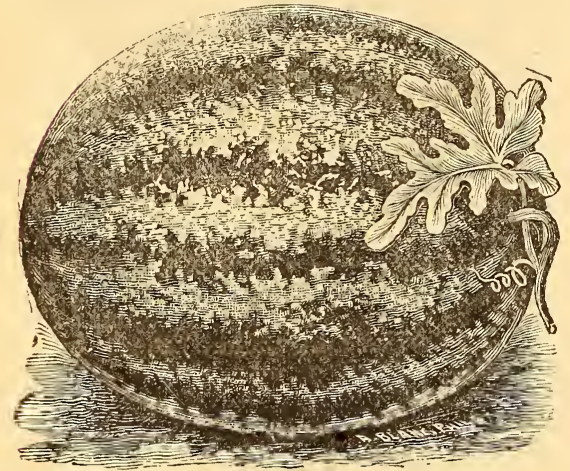

KOLB'S GEM, OR AMERICAN CHAMPION.

This new variety, first introduced in I884, originated in Alabama. It is a hy-brid of the Scaly Bark and Rattlesnake, and is an excellent shipping variety. It has a tough rind, and carries in good condition without breakage. The stripes of light green are generally narrow and of a dull color. The flesh is bright red and of good flavor. The melons grow to a fair market size, from thirty to fifty pounds each in weight.

Mammoth Iron Clad.-This magnificent new melon has fully sustained all that we claimed for it, and hasproven unequaled for market. Of oblong shape, it is very thick through, and retains its thickness at both stem and blossom end. The skin is beautifully striped with very light green. The shape is the most perfect that could be de-

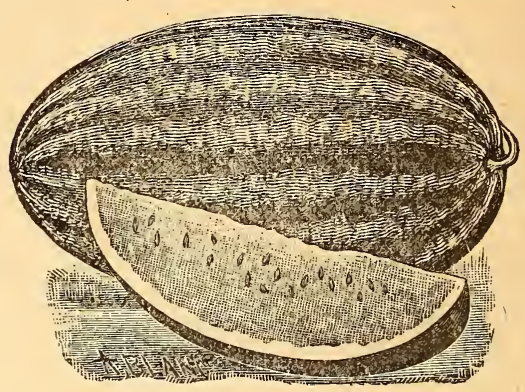

MAMMOTH IRON-CLAD.

sired. The seeds are of a drab-white color. The flesh is particularly beautiful, of a dainty red color, of rich, sugary flavor; the heart is very large, and passing the seed portion, the flesh next to the rind is fully equal to the heart in luscious taste. Mammoth Iron-clad grows uniformly to a larger size than any other variety known.

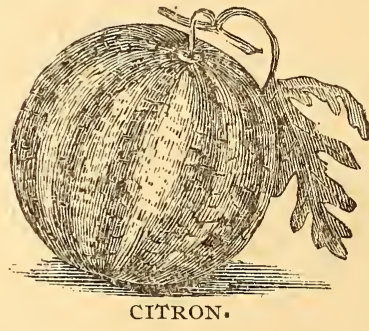

\section{MUSTARD.}

CULTURE.-Sow thickly during April and early in May, in shallow drills, press the earth well down, and for fall salad, in September; or in frames or boxes, in any outhouse, during Winter. Sow very thickly.

White London; for salad.

Blapck or Brown; for culinary use.

\section{OKRA.}

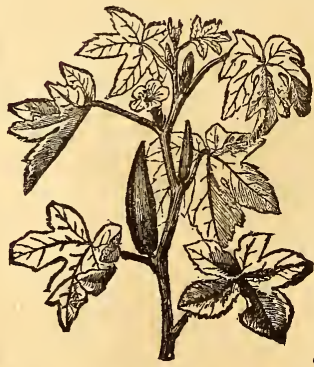

Cultivated for its green seed pods. The ripe seeds are often used as a substitute for coffee.

CulTure. - Plant late in Spring, after the ground has become warm, in drills three feet apart, where the plants are to remain. Thin out to nine inches.

DWARF GREEN, OR WHITE.
They should be well manured. 
Tall White; about four feet high; pods eight to ten inches long.

Dwarf White; two and a half feet high ; pods a foot long; very productive.

\section{ONION.}

The Onion is one of the most important of the culinary vegetables cultivated.

CUITURE. - A rather strong, deep and rich gravelly and loany soil is most suitable for this crop. The ground should be heavily dressed with rich, well rotted manure, trenched deeply, and ridged up early in autumn, and if the soil is of a light, sandy nature, cow manure will be most suitable. The main crop should be sown as early as the ground may be in working condition, and whether this occurs in March or April, sow the seed in drills, one inch deep and eight inches apart for onion sets, then well cultivated and kept clean of weeds, \&c.

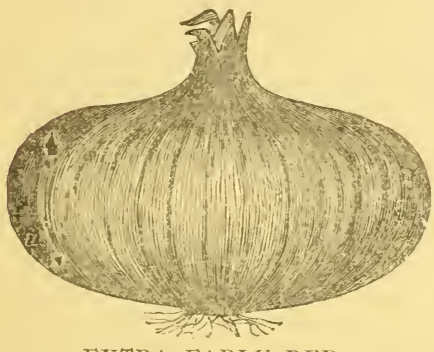

E x t r a Early Red; a medium, flat varie$t y, a n$ abunda $n t$ produce $r$, and very unin if or in in shape and size, and comes into us e two weeks earlier than the large red Wethersfield.

EXTRA EARIY RED.

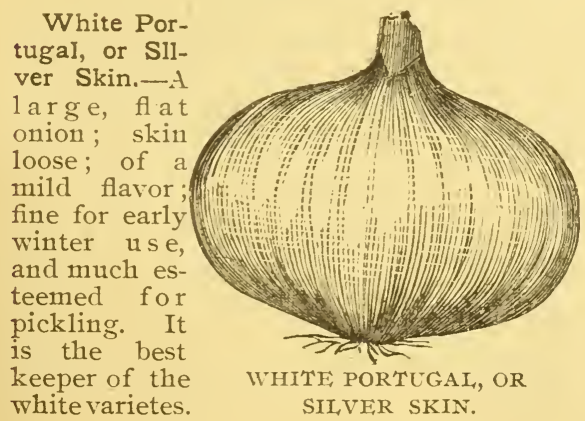

White Globe.-Yields abundantly, producing handsome and uniformly globe shaped bulbs. The flesh is firm, fine grained, and of mild flavor. Sometimes called Southport White Globe.

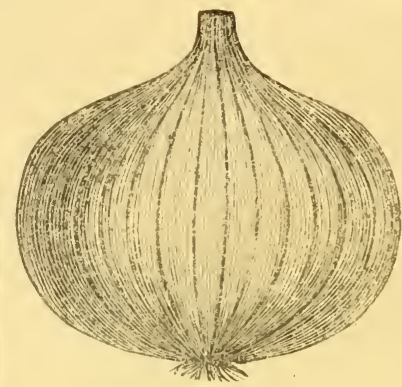

Yellow Danvers; a thick heavy, strawcolored onion, mild flavored, ripens early a n d keps equal to the best.

Large Red Wethersfield this is the standard ra-

YELLOW DANVERS. riety, and the favorite onion in the east, where immense crops are grown for shipment. Large size; skin, deep pur-

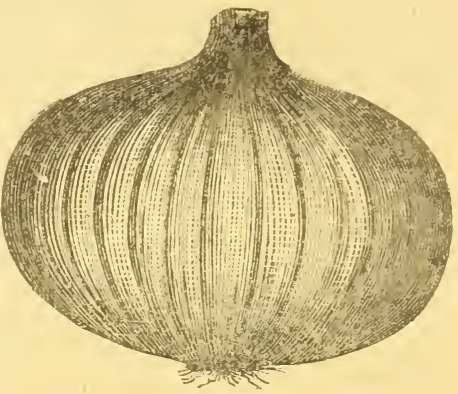

IVETHERSFIELD.

plish-red; form round, flat ; flesh, purplishwhite. Very proluctive, lise best keeper, and one of the most popular for general cultivation.

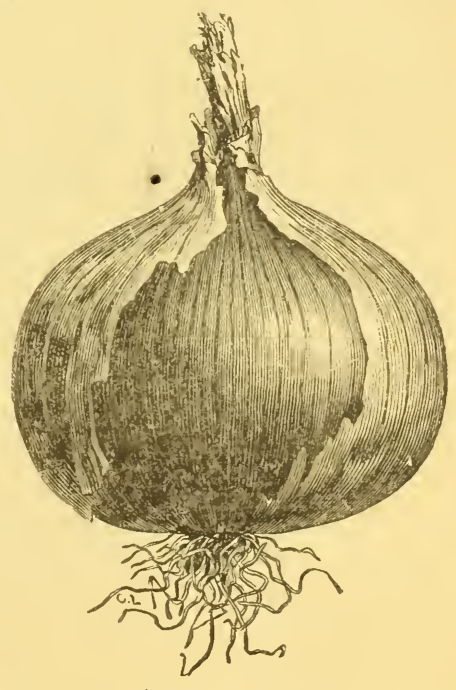

GIANT ROCCA.

Giant Rocca; an immense size onion, having attained three and one-half pounds. 
Globular in forn ; skin, light brown ; flesh mild and tender. It will produce large onions the first year from the seed, the smallest bulbs must be planted the second season to grow full sized onions.

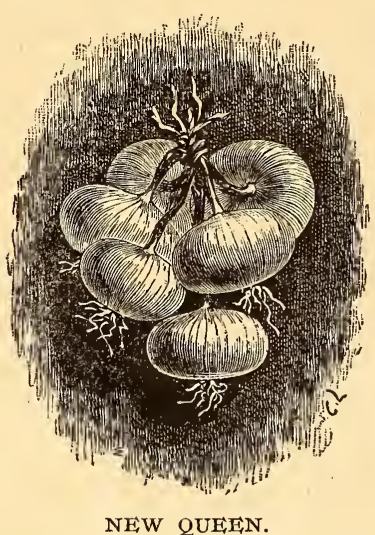

New Queen; a silver-skinned variety, of quick growth and remarkably keeping qualities.

Yellow Dutch; the common yellow variety, good to keep.

\section{PARSLEY.}

CULTURE.-Sow early in the Spring, the drills an inch deep and one foot apart. Thin out the plants to four inches apart.

Double Curled; used as a garnish for the table.

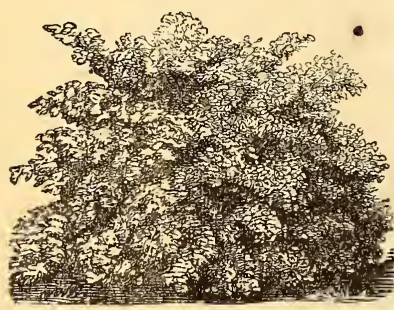

Myatt's Garnishing.- This variety is larger, an d the plant of strongerhabit than the preceding, with foliage as finely curled. The 1 e aves are bright

MYAT'T'S GARNISHING. green above, palerbeneath.

Admirably adapted for garnishing purposes.

\section{PARSNIP.}

CULTURE.-Sow as soon as the ground opens in the Spring, in drills one inch deep and fifteen inches apart.

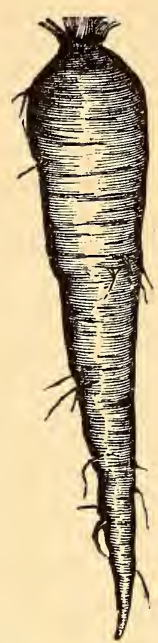

LONG WHITE DUTCH.

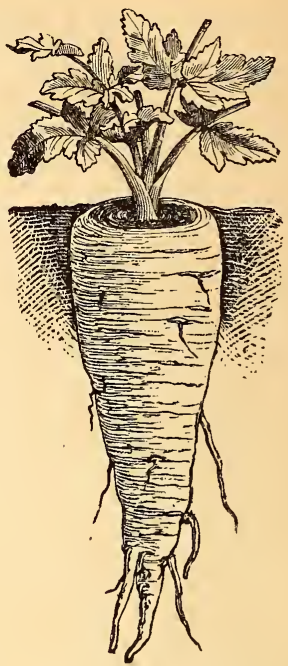

HOLLOW CROWN.

Long White Dutch; roots very long, white, smooth and tender. Keeps through the winter well, in the ground.

Hollow Crown; roots long; grows mostly below the surface; has a very smooth, clean skin, and is easily grown, and may remain in the ground during winter.

\section{PEAS.}

Those marked with $(*)$ are wrinkled varieties.

In spite of the multitude of varieties now in cultivation, there are each year many new sorts brought out, each of which is claimed to be superior. We take great pains to secure and offer the best varieties for sale.

CUITURE.-For early peas, the soil should be light, warm and sheltered, but for general crop, a moderately heavy soil is better. Sow as early as possible a few of the earliest variety on warm, quick soil prepared the fall before. The general crop can be delayed until later, but we have met with better success from sowing all the varieties comparatively early, depending for succession upon selecting sorts that follow each other in ripening. The first sowing will be earlier if covered only one inch deep; the other sorts should be covered from two to six inches deep, the deep planting preventing mildew, and prolonging the season.

The crop should be gathered as fast as it becomes fit for use. If even a few pods begin to ripen, young pods will not only cease to form, but those partly advanced will cease to enlarge. 
All Wrinkled Peas are superior to, more delicate in flavor, and remain longer in season than the smooth sorts, for, as in sugar corn, the wrinkled appearance indicates a greater amount of saccharine matter.

\section{Extra Early Sorts and Dwarf Varieties.}

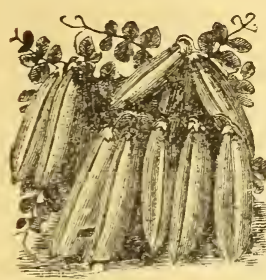

BLISS' AMERICAN WONDER.

*Bliss' American Wonder; this variety is justly entitled to its position at the head of the list, and stands unrivaled in point of productiveness, flavor and quality; a cross between the Champion and Little Gem, and is, without exception, the earliest wrinkled Pea in cultivation; it is of dwarf and robust habit, growing from Io to 15 inches high, and produces a profusion of good sized and well filled pods of the finest flavor.

Philadelphia; extra early; favorite market variety.

Rural New Yorker; early, productive, and uniform in ripening. It grows about 20 inches high, and is quite similar to our Philadelphia Extra Early.

Tom Thumb; very dwarf, not exceeding 9 inches in height, stout and branching; very early, of excellent quality, yields abundant$1 \mathrm{y} ;$ it requires no sticks.

Blue Peter, or Blue Tom Thumb; needs no sticks; nine inches high, of robust habit and strong growth.

*McLean's Little Gem; a dwarf, prolific green, wrinkled Marrow; habit similar to the Tom Thumb; a great acquisition; very early; height I foot; require no sticks.

*Premium Gem; growing about fifteen inches high, and among the earliest dwarf, green wrinkled sorts.

*Laxon's Alpha; one of the earliest wrinkled Peas ; blue, of exquisite flavor, remarkable for its earliness and prolific bearing ; it bears pods, well filled and of good size, down to the bottom of the haulm

\section{FOR GENERAL CROP, Late Varieties.}

*Bliss' Everbearing. - A new variety maturing soon after the Gems, and continuing a long time in bearing. Vine stout, about eighteen inches high, bearing at the top six or ten broad pods. If these are removed as they mature, and the season and soil are favorable, the plant will throw out from the axil of each leaf branches bearing pods which will mature in succession, thus prolonging the season. Peas wrinkled, large, cooking quickly, and very tender, of superior flavor.

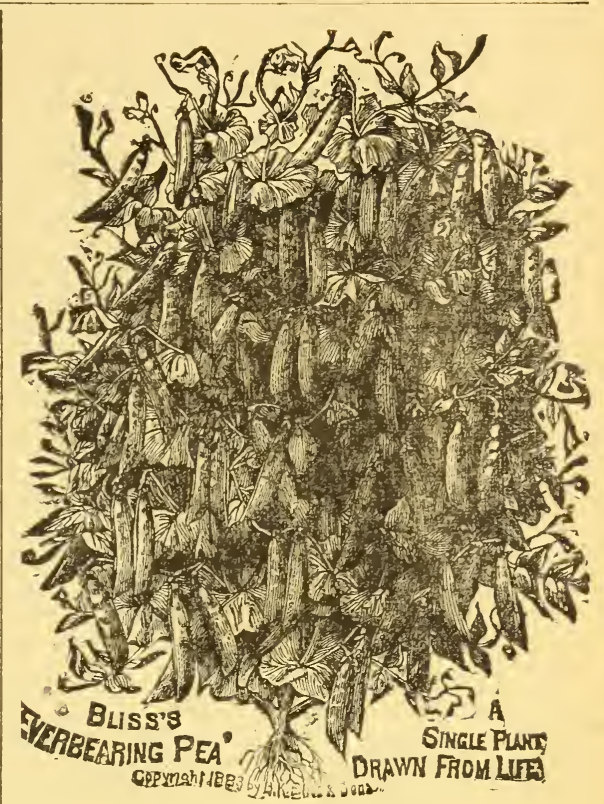

Early Kent; growing about two and a-half feet high. Pods well filled with good sized Peas; very productive.

Carter's First Crop; an English variety; very early, productive, good flavor; grows $21 / 2$ feet high, the hauln being literally covered with pods.

*McLean's Advancer; a green, wrinkled variety, about two and a-half feet high, with long pods, which are abundantly produced, and well filled to the end. Nearly as early as the Extra Early Kent, and of most excellent flavor.

Owarf White Marrowfat; a large, delicious marrow pea; an excellent cropper, and a favorite with market gardners; height two feet.

Dwarf White Sugar.-Edible pords; can" be used either shelled or whole, the pods, when young, being sweet and tender; two feet in height.

Dwarf Gray Sugar, Edible Pods.-Grows about two feet high, and is remarkable for its earliness as well as its prolific character. The seeds are large, shriveled and indented, of a dark brown color. The pods are broad, flat and crooked, and contains five or six peas.

Tall Sugar.-Edible pods; about five feet in height, very sweet and tender. 


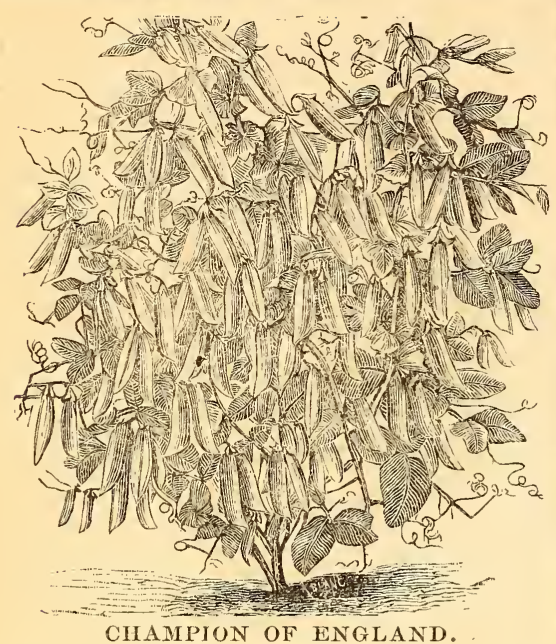

*Champion of England.-Universally admitted to be one of the richest and best flavored Peas grown, and very productive. Height, four or five feet; seed, whitishgreen and much shriveled, and will always sell, green, better than any other variety.

Large Blue Imperial.-A bout three feet high, and very strong. Pods large, long, pointed, rather flat, containing eight or nine peas. Seed large, blue and a little flattened. A good bearer, and one of the best varieties for summer use, but requires to be planted early, or it will be apt to mildew.

Large White Marrowlat.-One of the oldest American varieties, About five feet high, of strong growth. Pods, large, round, rough, light colored and well filled; seed, large, round, and yellow or white, according to the soil in which they are grown.

*Bliss' Abundance.-Plant half dwarf, fifteen to eighteen inches high; foliage large, thick, full and dark green. Pods three to three and a-half inches long, roundish and well filled, containing six to eight large wrinkled peas, of excellent quality. It ripens second early, being fit for the table about ten days after the earliest kinds. The most striking feature of this variety is its remarkable tendency for branching directly from the roots, forming a veritable bush. Many plants throw out six and more branches, each of which becomes literally covered with blossoms and pods, in such abundance that the quantity produced by each branch would be considered a beautiful yield for an entire plant of many of the older varieties. This branching habit makes it necessary to sow the seeds much thinner than usual. Six to eight inches apart in the rows is as near as the plants should stand; if the soil is very rich, eight inches is preferable.

\section{PEPPER.}

CULTURE.-Sow in hot beds in March, or in open ground in a seed-bed in middle of Spring, in light, warm ground. When three inches high, transplant to eighteen inches apart each way, and cover with hand glass. Hoe frequently.

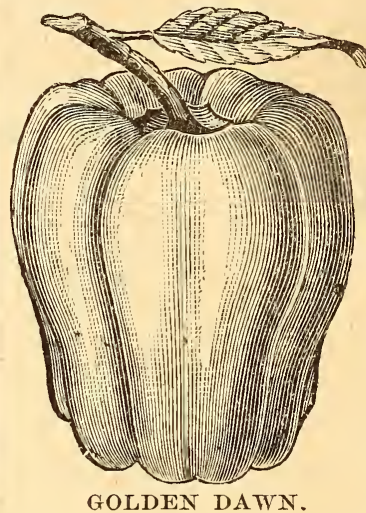

Golden.Dawn.shape resembling the popular Bell or Bull-Nose pepper; it is of a most beautiful golden yellow color, making a very handsome a p pearance, both in growth and on the table. It is very sweet; even the seeds may be handled or eaten without detecting the slightest fie ry flavor. Very productive ; the dwarf, bushy plants being completely laden with the bright colored fruits.

Large Bell, or Bull Nose. - A very large sort, of inverted bell shape, suitable for filling with cabbage, etc., and for a mixed pickle. Flesh thick, hard and less pungent than most other sorts; and one of the earliest varieties.

Sweet Mountain, or Mammoth. - Similar to the Bull Nose but larger and milder in flavor. Used to make stuffed pickles.

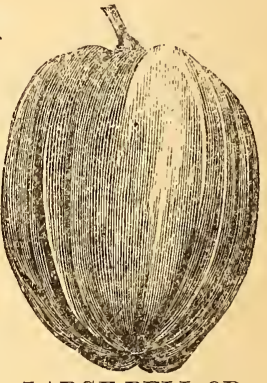

LARGE BELL OR BULL NOSE.
Long Red Cayenne (True,)-Long fruits, of conical shape, bright red; flesh strong and pungent.

\section{PUMPKIN.}

The Pumpkin more properly belongs to the farm than the garden, especially as it readily mixes with and injures the qnality of the finer squash.

CuLTURE.-May be planted middle of May to the first of June, in the field or garden, in hills 8 feet apart each way, 3 seeds to the hill. 


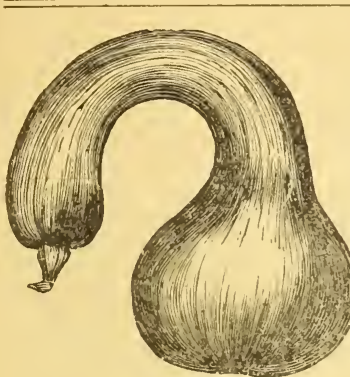

CASHAW.
Cashaw (crooked neck); in form $\mathrm{much}$ resembling the White Crookne $\mathrm{k}$ Squash, though growing to a very large size, fre que n t 1 y weighing 70 pounds ; color, light cre a m, $\mathrm{s}$ o $\mathrm{m}$ e $\mathrm{t}$ i m e s slightly striped with green; very productive and the most profitable of the pumpkin family.

Large Gheese (Sweet Pumpkin); one of the best for table use, productive. skin green and orange, flesh yellow and sweet.

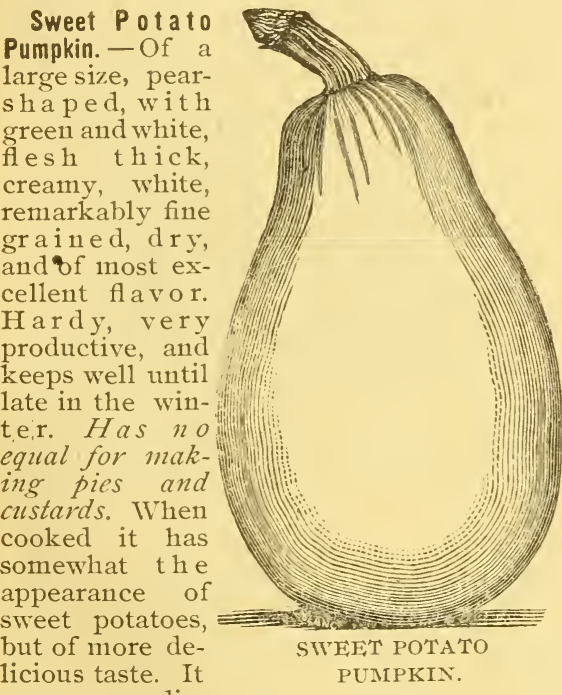
proves very dis

tinct, and is a valuable acquisition. This variety we recommend as being superior to any other variety of pumpkin for cooking purposes. Our stock of seed is grown with special care.

Connecticut, or Large Common Yellow Field.A very productive, large yellow variety, and grown principally for feeding stock.

\section{RADISH.-Early Varieties.}

Cultivated for its roots, which should always be eaten when quite roung, as the be pithy and tough when full grown. The young seed leaves are used as a small salad, and the green seed pods for a pickle.

Culture.-Sow as early in Spring as the ground can be worked, and every two weeks till the middle of June. Winter varieties from the first of August to the first of September. A light, rich soil suits best.

It should be borne in mind that radishes must have plenty of room, and be grown quickly, or they will invariably be tough and wormy.

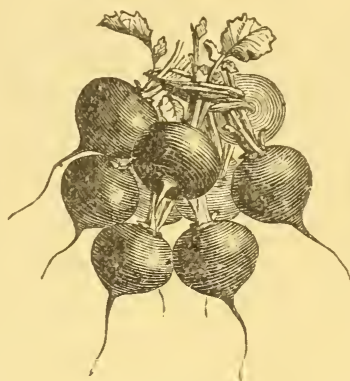

Warly Scarl et, Tur i $\mathrm{n}$ Rooted.-A small, round, red, turnip shaped radish with a small top, and of very quick grow th. A very early variety, deserving general cultivation on account of its rich solor, crisp and tender qualities.

EARLY SCARLET TURNIP.

Early White

Turnip; like the Scarlet Turnip in shape, but in color pure white.

Early Scarlet Turni p, White Tipped; a beautiful variety, deep scarlet with white tip. It is very ornamental for table use, and is becoming very popular as a market variets.

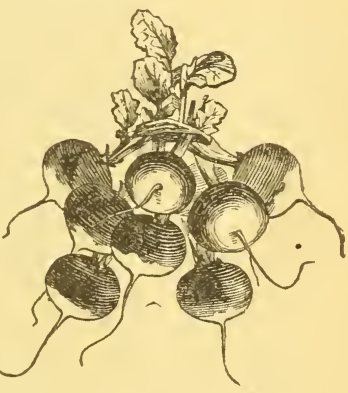

EARLY SCARLET TLRNIP, WHITE TIPPED.

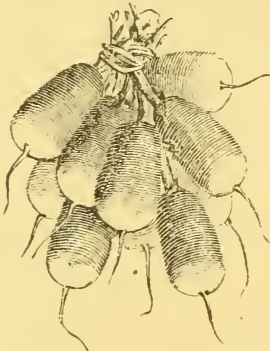

French Breakfast.- medium sized radish, olive, shaped, small top, of quick growth, very crisp and tender, of a beautiful scarlet color, except near the root, which is pure white. A splendid variety for the table, not only on account of its excellent qualities, but for its beatiful color.

FRENCH BREAKFAST.

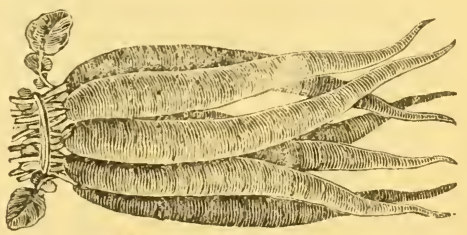

EARLY LONG SCARLET. 
Early Long Scarlet, Short Top ; this is unquestionably the best standard variety for private gardens and market use. It grows six or seven inches long, half out of the ground; it is very brittle and crisp, and of quick growth; color, bright scarlet; small top; tapers regularly to the root.

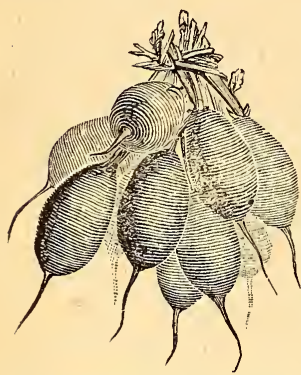

Early Scarlet, Olive Shaped.-In the form of an olive, terminating in a very slim tap root. Skin fine, suarlet; neck small ; flesh rose colored, tender and excellent. Early, and well adapted for forcing or general crop.

SCARLET OLIVE-SHAPED.

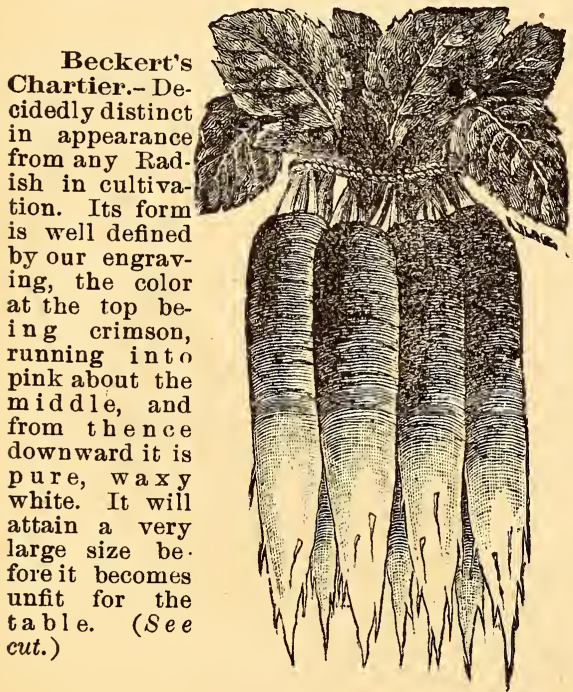

BECKERT'S CHARTIER RADISH.

Winter Varieties.

Black Spanish Winter, Long; of very large size and firm texture, with dark green leaves. It must be stored in sand in the cellar for Winter use.

Scarlet China, Winter ; form, rather conical, and very smooth; of a lively rose color ; flesh, firm, like the black spanish, but more pungent.

\section{RHUBARB, OR PIE PLAT.}

Fr. Rhubarbe.

Ger. Rhubarber.

Rhubarb, familiarly known as Pie Plant, is cultivated in gardens for the leaf stalks, which are used for pies and tarts.
Linaeus; the earliest of all and the best.

\section{SALSIFY.}

Culture.-Cultivate the same as for Carrots.

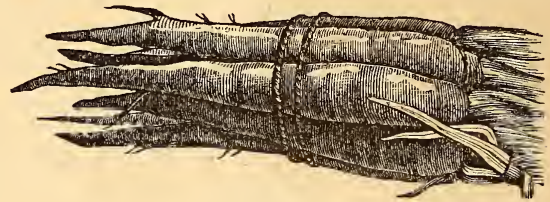

SALSIFY.

Oyster Plant; when cooked the flavor resembles the oyster and is a substitute.

\section{SPINACH.}

CULTURE.-Rich soil; sow a half inch deep, and a foot between the rows. Thin out to eight inches. Sow as soon as frost is out of the ground, and hoe frequently to prevent the plants running to seed. For Winter crop sow end of August and in September.

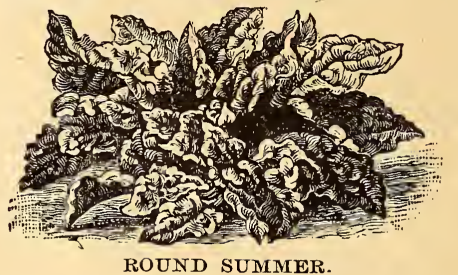

Round Summer.-The main market sort equally good for either fall or spring sowing, principally used as greens.

\section{SQUASH.}

Fr. Courge. Ger. Kuerbis.

The Squash is one of the most nutritious and valuable of all our garden vegetables. The summer varieties come to the table early in the season, and are very palatable, while the winter sorts can be had in perfection from August, until the summer varieties are again in condition.

Culture.-Plant in hills, in the same manner and at the same time as cucumbers and melons; the bush three or four feet apart, and the running kind from six to nine.

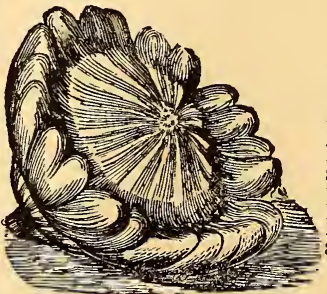

Early Bush or Patty Pan.-The best early variety for market or shipping ; It grows to a large size, iscolloped like a Patty pan, and bearing an abundant crop.

EARLY BUSH OR PATTY PAN. 


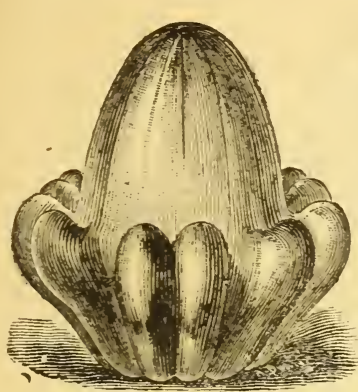

WHITE PINE APPLE.

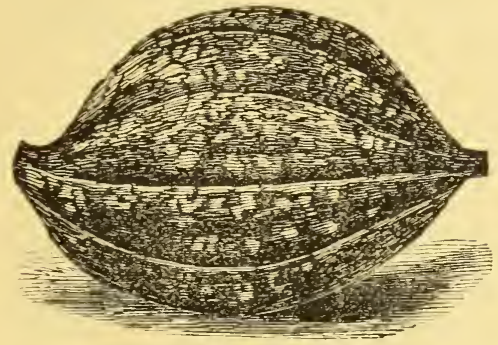

MARBLEHEAD.

Marblehead; A new variety of great value. The flesh is of rather lighter color than the Hubbard, while its combination of sweetness, dryness and delicious flavor is remarkable, its keeping qualities are declared to surpass the Hubbarl.

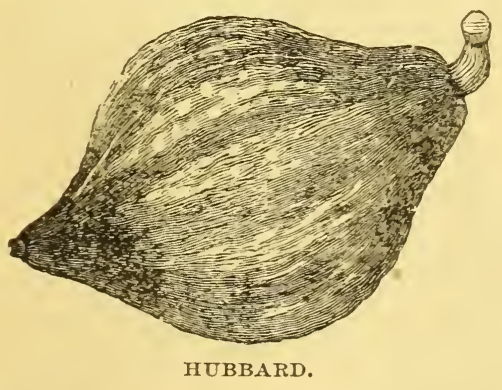

Hubbard; the best table squash yet known; good specimens being about equal in quality to the Sweet Potato. It has a hard shell, and with the same care will keep three months later than the Marrows.

Mammoth Chili; rery large, often attaining the weight of two hundred pounds and upwards; excellent for pies or stock; very productive. We hare grown them to weigh 141. pounds. Experienced cultivators have grown them weighing 300 pounds and upwards.

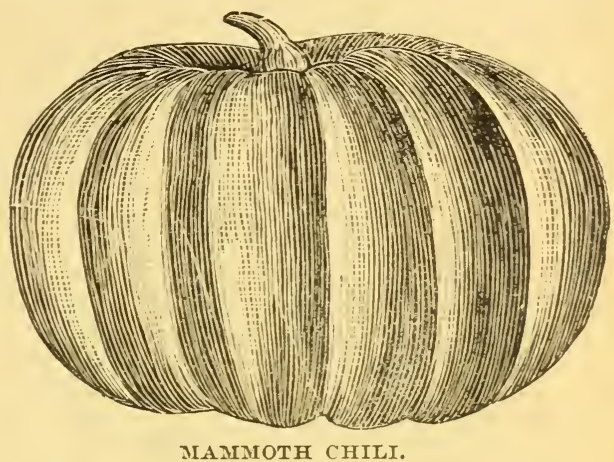

TOMATO.

This vegetable is too well known to need any description. There has been a great improvement in it during the last few years, and the varieties now offered are greatly superior to those known a few years ago.

Culture.-Sow in hot hot-bed in March, and transplant into the open ground when weather becomes warm and settled, or sow in open ground in May, and transplant When plants are 6 inches high, 4 feet distant from each other. Soil should be made rich and ight.

\section{First Early Sorts.}

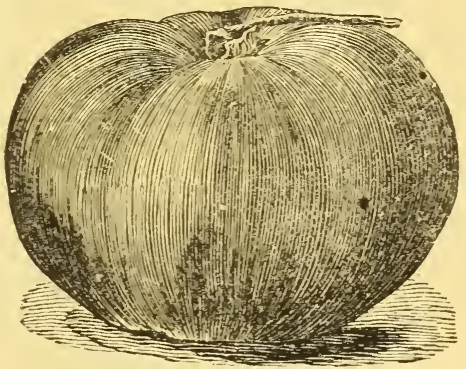

CAYADA VICTOR.

Canada Victor (new ;) without a doubt the earliest in cultivation, and has proven itself to be the earliest medium to large tomato in use ; colored red and very smooth, ripening the greater bulk of the crop. The seed we offer is taken from the earliest and best specimens for seed.

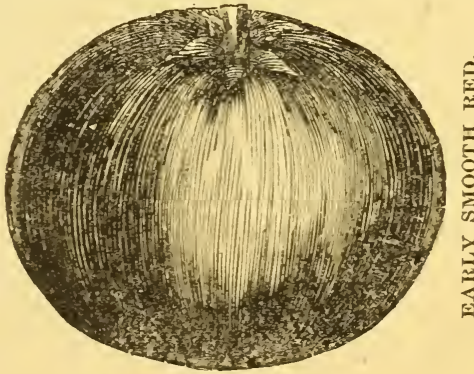


Early Smooth Red; one amongst the early varieties, color red, surface smooth, solid and of uniform size. A valuable market variety.

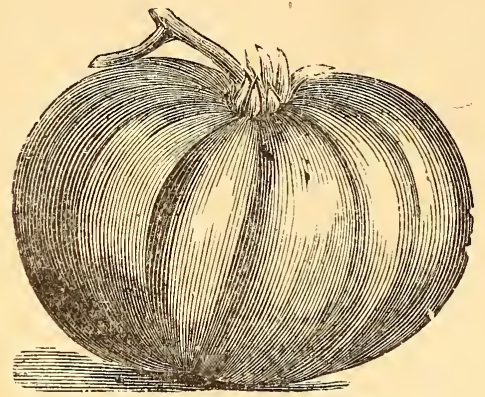

HATHAWAY'S EXCELSIOR.

Hathaway's Excelsior.-(See cut.) Smooth as an apple, very solid, and of excellent quality; very productive and an excellent market variety.

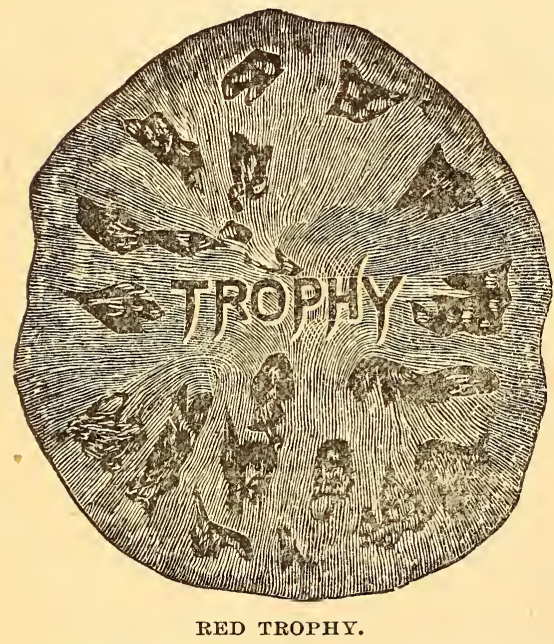

Red Trophy; the best for the main crop and undoubtedly is the best new variety that has yet been brought into use. It is of a very large size, uniformly smooth and well formed; solid to the centre, and very heavy. The seed we offer is of our own growth and the best specimens selected for seed.

Golden Trophy.-Like the well-known Red Trophy in shape, but of a pure golden yellow color. The tomatoes are of large size and solid; very productive-

Paragon.-Vine very large, vigorous and productive, and continuing so until killed by frost. Fruit large, round, of a very dark, rich crimson-scarlet color, with occasionally a purplish tinge. It ripens up evenly, and the flesh is thick and fine flavored.

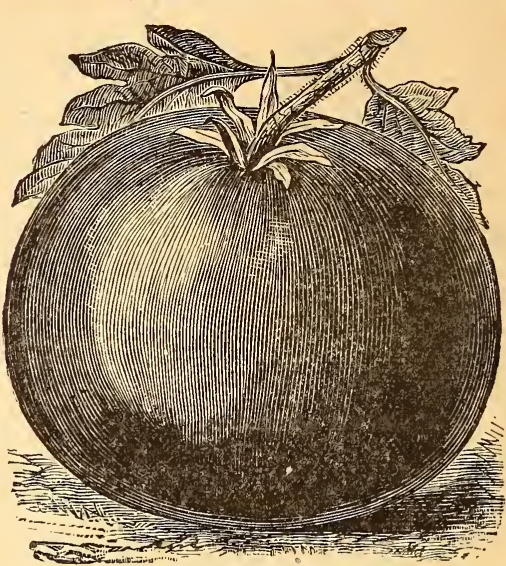

LIVINGSTON'S PERFECTION.

Livingston's Perfection.-A new variety similar to the last, but an improvement upon it, it being a little earlier, and invariably smooth and handsome. It is probably the handsomest tomato grown, and all who have tried it pronounce it of the bighest quality.

Livingston's - Favorite.-Vine medium, with large, dark green, healthy leaves, having numerous clusters of frow three to seven very large, smooth tomatoes, which are a rich, dark red color, oval outline, exceedingly smooth ; flesh very firm but without green spots. This is a favorite variety with many on account of its smooth, handsome fruit.

\section{IFIE MIIFX \\ OR TURNER'S HYBRID TOMATO.}

One of the Earliest and of the Largest Size. Perfectly Solid and of Unsurpassed uuality.

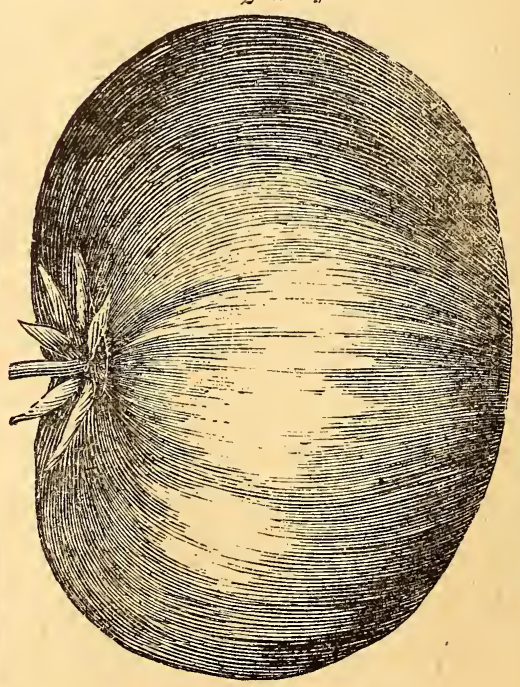


A new variety of immense size, perfect solidity and unsurpassed quality. Whether for slicing or for cooking purposes the quality is most excellent. The tomatoes are borne in clusters of 4 to 7 , ripen evenly, and remain firm when fully ripe. In color and solidity it resembles the Trophy. The foliage of the Mikado Tomato alone will show the distinctiveness of the variety, for it is different from that of any other that has come under our observation, while in all other varieties the leaves are cut or serrated.

\section{TURNIP.}

Fr. Navet.

Ger. Rueben.

This wholesome and agreeable vegetable has been cultivated from time immemorial as a field crop, and is one of the staple products of the farm. It is most easily affected in its form and flavor by soil, climate and mode of culture. There are a great many varieties, but we have selected the following as the best for the garden or farm.

Culture.-Sow in drills fourteen inches apart, and half an inch deep, or they may be sown broadcast, but in either case be sure to have the ground freshly dug. Keep them perfectly free from weeds. For the spring and summer crops, it is important to get them started very early so that they may have time to grow to sufficient size before hot weather, when they will soon become tough and strong.

White Fleshed Sorts.

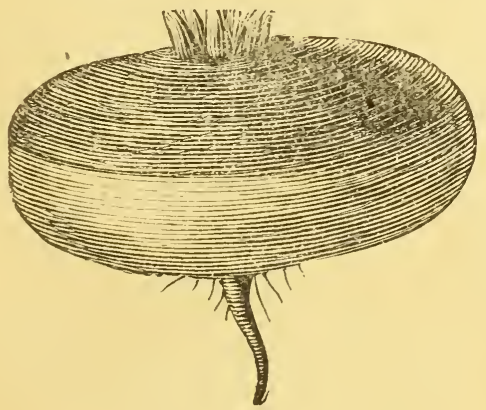

EARLY PURPLE TOP.

Early Purple Top (Strap Leaf;) this variety has the form and character of the Whitetop, except in color, which is red or purple above ground. For the main crop this variety is more largely grown than any other, and has no superior.

Early White Flat Dutch, Strap Leaved. -A most excellent, early, garden variety, much used in the Southern States. Is sure to bottom; very early sweet and tender, and grown for table use. This variety is similar to the purple top strap leaf, in size and shape. Flesh fine grained and of mild flavor; a good keeper.

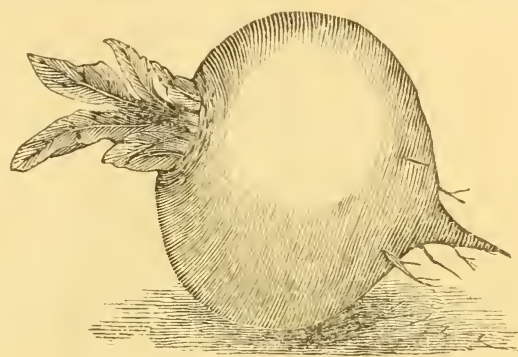

WHITE GLOBE PONERANEAY.

White Globe Pomeranean.-Is one of the most productive kinds ; in good, rich soil, the roots will frequently grow to twelve pounds in weight; it is of the most perfect globe shape; skin, white and smooth ; leaves, dark-green, and of strong growth.

Long White, or Cow Horn.-Flesh white, fine grained, and sweet; keeps well, and is one of the best of all for culinary purposes.

Yellow Fleshed Sorts.

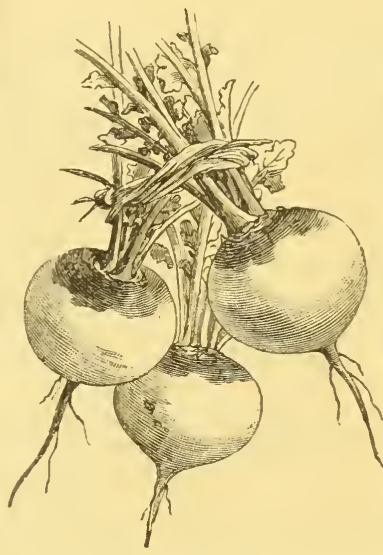

Large Yellow Globe.$\mathrm{Th}$ is variety grows to alarge size, handsome, globular shaped, color pale yellow with greenish top leaves, rather small and spreading. One of the best for a general crop, either for table use or stock ; keeps hard and brittle until late in Spring.

LARGE YELLOW GLOBE.

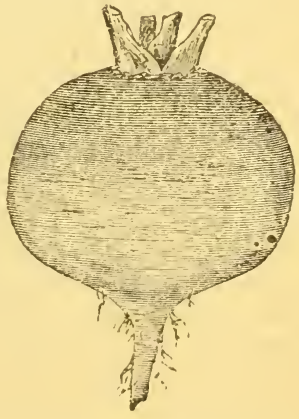

IELLOW ABERDEEN. -Of round form, pale yellow flesh, of fine texture, solid, nutritious and a good keener. Very popular for cattle feeding, and also adapted for table use late in winter,
Yellow Aberdeen 


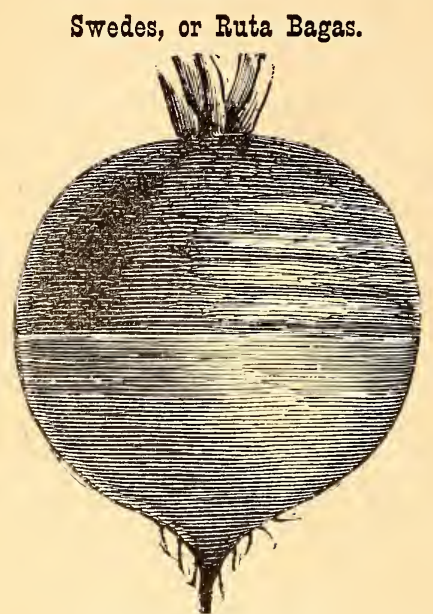

LAING'S RUTA BAGA.

Laing's Improved.-A handsome variety of excellent quality; purple above and yellow under ground; almost perfect globeshaped when well grown.

Carter's Imperial Hardy Purple Top Yellow Ruta Baga.-A most excellent sort for either table use or feeding stock. Flesh yellow, solid, firm, sweet and rich. It is a hardy sort, yields heavily, with no tendency to long necks.

Sweet German.-Bulb four or five inches in diameter and six or seven in depth; neck two or three inches long; skin greenishbrown above ground, white beneath; flesh pure white, of extraordinary solidity, very sweet, mild, well-flavored; retains its solidity and freshness until spring.

\section{THE LAWN.}

Extra Fine Mixed Lawn Grass (Central Park Mixture.)-The essentials for a fine lawn are proper drainage, a careful preparation of the soil, which should be made as fine and light on the surface as possible, thorough rolling, and a selection of the seeds of such grasses as will present aluxuriant verdure from early spring till late in autumn; and then frequent mowings with a lawn mower. One pound of this mixture is sufficient to sow a space $30 \times 20$ feet, or 600 square feet. Kentucky Blue Grass in conjunction with White Clover forms one of the finest and closest of lawns. For this purpose use three or four bushels of Blue Grass, and about six pounds of White Clover per acre.

Purple Top, or American Improved.The leading variety; very hardy and productive; flesh yellow, solid, sweet, and fine flavored; equally good for stock or table use; the principal variety raised by market gardeners, and the best of all yellow Turnips.

\section{SWEET, POT, AND MEDICINAL HERBS.}

No garden is complete without a few herbs for culinary or medicinal purposes, and care should be taken to harvest them properly. This should be done on a dry day, just before they come into full bloom, then dry quickly and pack closely, entirely excluded from the air. Sow in spring, in shallow drills, one foot apart, and when well up thin out or transplant a proper distance apart.

Basil, Sweet.

Marjoram, Sweet.

Saffron (Carthamus Tincltorius.)

Sage (Salvia officinalis.)

Savory, Sammer, \&c., \&c.

\section{Special Dollar Collections. $\$ 1.00$}

Will bring jou, by prepaid mail, any one of the following collections. (Order by number.)

1. 12 Choice Everblooming Roses, notwo alike.

2. 8 Hybrid Perpetual Roses, no two alike.

3. 4 Moss Roses.

4. 6 Climbing Roses.

5. 4 Polyantha Roses.

6. 6 Wverblooming, 4 Hyb. Perpetual Roses

7. 1 Moss, 4 Tea, 3 Hyb. Perpetual Roses.

8. 2 Climbing, 1Moss, 2 Hybrid Perpetual, 3 Everblooming Roses.

9. 12 Concord Grape Vines.

10. 5 Rogers' Grape Vines best sorts.

11. 6 Concord, 2 Rogers'.

28. 4 Hydrangeas-Otaksa, Grandiflora, Thos. Hogg, Hortensis.

29. 1 Ampelopsis, 3 Honeysuckles, 3 Shrubs, 1 Hydrangea Otaksa.

30. 12 Tuberose Bulbs.

31. 6 Everblooming Roses, 12 Cuthbert Raspberries.

32. 10 Everblooming Roses, 1 H y d ra n g e a Otaksa.
33. 6 Everblooming Roses, 1 H ydrangea Otaksa, 1 Hydrangea Grandifiora.

34. 4 Everblooming Roses, 12 Cuthbert Raspberries, 1 Hydrangea Otaksa.

35. 3 Clematis-Coccinea, Crispa, Jackmanii. 36. 12 Chrysan themums, fine, no two alike.

3\%. 6 Chrysanthemums, 6 Everblooming Roses 38. 5 Roses, 4 Chrysanthemums, 1 Hydrangea Otaksa.

39. 6 Best Hardy Climbing Plants, including 2 Clematis.

40. 25 Strawberries, 12 Cuthbert Raspberries.

41. 6 Currants, 12 cuthbert Raspberries.

42. 3 Rogers' Grapes, 12 Cuthbert Raspberries.

43. Currants, 4 blackberries, 12 Raspberries.

44. 12 Choice Mixed Gladioli Bulbs.

45. 6 Gladioli, 6 Tuheroses.

ANY SIX of the above Collections for $\$ 5$; any THIRTEEN for $\$ 10$. 


\section{A SELECT LIST}

\section{.

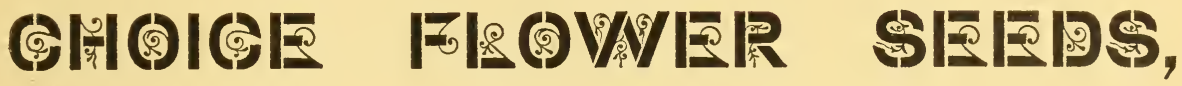

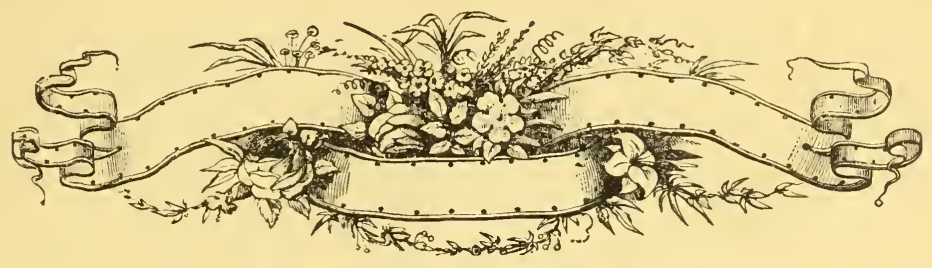

\section{American, English, French and Germam,}

Embracing Annuals, Biennials and Perennials.

The term "ANNUAL," is given to those plants which grow flower seed, and die within the same year.

"BIENNIALS" are those plants that do not generally flower until the second season, and after blooming, die.

"PERENNIALS" are those that do not generally bloom until the second year, but continue to bloom for years, and may be propagated by a division of the roots.

We offer the following liberal inducements to Clubs, or those who wish to purchase VEGETABLE and FLOWER SEEDS in quality. These low rates apply only to Seeds in Packets, but the Seeds will be sent by mail, post-paid.

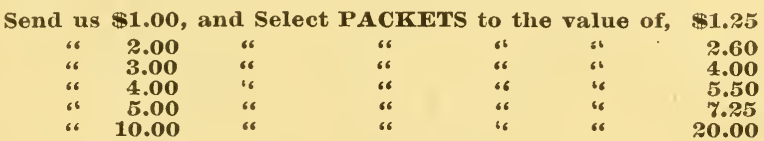

All Flower seeds sent free by mail on receipt of price.

REMITTANCES may be made by Post Office Order, or Postal Note, by Express, or by Registered Letter; but $P$. O. Order is preferable. When the amount is small, say one or two dollars, the currency can usually be sent safely with the order.

SIGN YOUR NAME.-In sending for Seeds by mail, give your Name, Post Office, County and State, and write every letter so plainly that there can be no mistaking it.

The Cash must ALWAYS be sent with the order. 


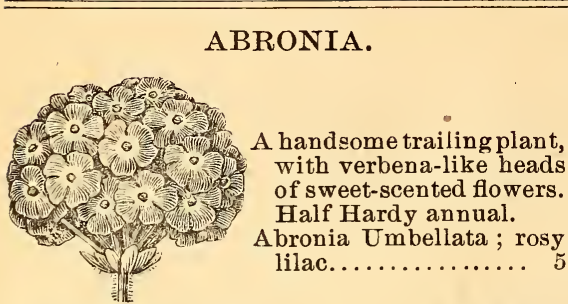

ABRONIA.

\section{ABUTILON.}

(CHINESE BELL FLOWER, FLOWERING MAPLE.)

Flower freely during the spring and winter months in the house, and during summer when bedderi out; the flowers are bell-shaped, and in the varieties are to be found $\mathrm{crims}$ on grounds, streaked with yellow; yellow grounds, veined red; pure white and clear yellow. Can be propagated by cuttings, in sand, under glass, during summer. If seeds are sown.

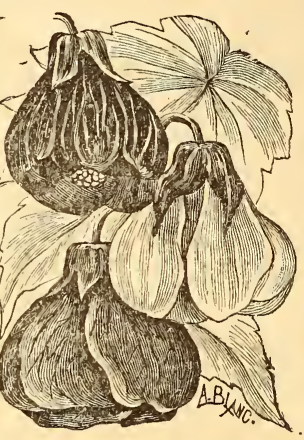

HYBIRD ABUTILON. before April, under glass, plants will bloom the first season. For winter flowering, sow in August or September. Perennials.

Abutilon. Fine mixed, of above shades, 2 to

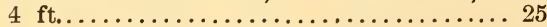

\section{ACROCLINIUM.}

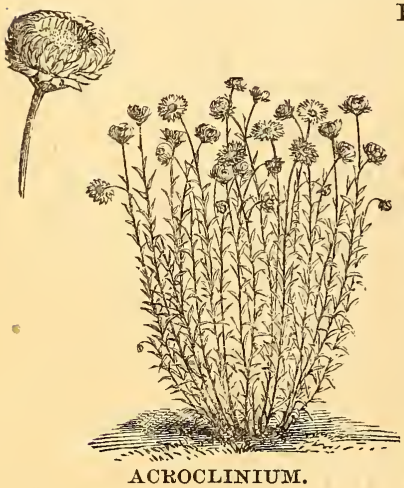

Beautifuleverlasting flower, grown extensively for winter boquets and ornaments ; native of W e s ter $n$ Australia ; color offlow. ers rose and white, daisy like in appearance, and borne on stems 15 inches long; $\mathrm{h}$ a lf-hardy annual. To preserve the flowers, they should be picked before fully open to secure a bright center when dried. Acroclinium ; mixed colors............. 5

\section{ADLUMIA.}

A beautiful biennial climber with light green foliage. Sow seed in early spring near a trellis or arbor, and the following year it will

blossom freely, without any other care or protection. Native of the Alleghany mountains. Color of flowers are pink and white.

Adiumia Cirrhosa.................. 10

\section{ADONIS.}

Sometimes called Flos Adonis and Pheasant's Eye. The foliage is fine and pretty, the flowers brilliant scarlet. They will do well in partial shade, and may be planted in any retired corner of the garden. Twelve to eighteen inches in height.

Adonis Autumnalis. (Pheasant's Eye.) Crimson, 1 fit.....................

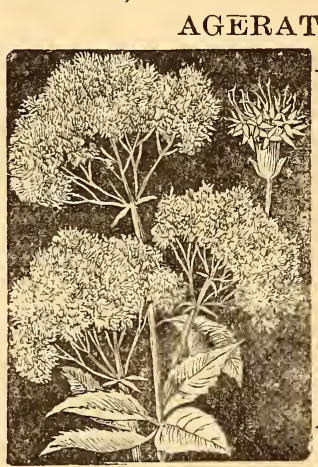

AGERATUM.

\section{AGROSTEMMA.}

Perfectly hardy plants producing $p$ retty, pink-like blossoms on long, slender stems. Very useful for cutting for bouquets, a nd pretty in masses, in beds. The annual variety is known as $\mathrm{R}$ o s e o f Heaven; the perennial as Rose Campion. About one and

a half feet high. AGROSTEMMA CGELI ROSA. Agrostemma Cœli Rosa..............

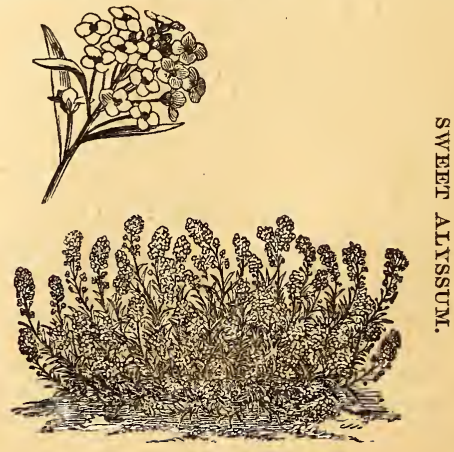




\section{A L YSSUM.}

Alyssum, sweet (maritimum.) A desirable hardy annual, fiowering from early spring till killed by frost, and all winter in the green-house if sown in August. Flowers pure white, in racenues, and of a peculiar delicate fragrance. Most effective in masses, with plants one foot apart. Useful in all kinds of small bouquets. Grows one foot high........................ 5

Alyssum, golden (saxatile.) Flowers brilliant golden yellow, completely hiding the foliage. Plants about one foot high ; desirable for rock work, and quite showy in mass-

es. Hardy perennial................ 5

\section{ALONSOA.}

The flowers are remarkably brilliant, and are scarcely equalled among the crimson and scarlet flowers.

Alonsoa; mixed................... 5

\section{AMARANTHUS.}

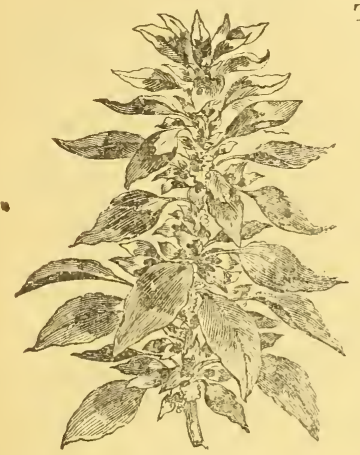

The Amaranthus include numerous plants, valuable for the beauty of their foliage, many of the varieties having handsomely formed and highly colored leaves, while others are remarkably for lo $\mathrm{ng}$, l a r g e, drooping panicles of $\mathrm{s} \mathrm{m} \mathrm{a} 1 \mathrm{l}$ flowers, forming immense clusters, which are wonderfully effective Seed

AMIARANTHUS may be sown in a warm border, from which they are easily transplanted, or they may be sown where plants are to bloom.

Amaranthus Caudatus (Love Lies Bleeding.) Long drooping flowers, deep red color.... Joseph's Coat. Amaranthus Tricolor (Joseph's Coat.) Handsome foliage, red, yellow and greenish-colored leaf................ 5

Melancbolicus ruber, compact habit, striking blood red foliage; 18 inches high........ 5

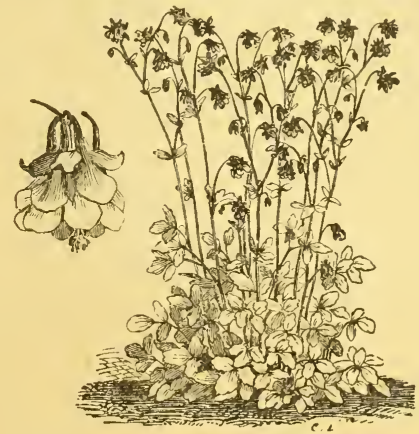

AQUILEGIA, OR COLUMBINE.

\section{AQUILEGIA.}

The Aquilegia is the old and well-prized Columbine, of almost every conceivable color and singular variations of form. like a good many of our hardy perennials, this flowers early in the spring; seeds may be sown in the open ground; plants can be increased by a division of the roots; it grows wild in most every country in the world; called by some the IVild Honeysuckle.

Aquilegia; double mixed colors......... 5

\section{ANAGALLIS.}

Interesting plants of easy culture, and remarkable for the beauty of their flowers. They are well adapted to rock work or borders. Planted under glass and transplanted into light rick soil, in a sunny situation, they will cover the ground all summer with a profusion of bright, rich colored flowers. Half-hardy annual; about six inches high.

Anagallis, mixed.................. 10

\section{ANTIRRHINUM.}

An old favorite border plant with curiously shaped flowers, with finely marked throats. Half hardy perennial.

Antirrhinum (Snapdragon)...........

\section{ASTERS, CHINA.}

It seems scarcely necessary to speak of the merits of such a universally growu plant as this; yet there may be some who are not aware of the great strides that have been made in the last few years in improved strains and of the distinct new races that have been originated. Conspicuous among these we may mention the Crown, Goliath and Victoria classes, which will be a pleasant surprise to those who may this season for the first time grow them. Half-hardy Annuals.

\section{CROWN, OR COCARDEAU.}

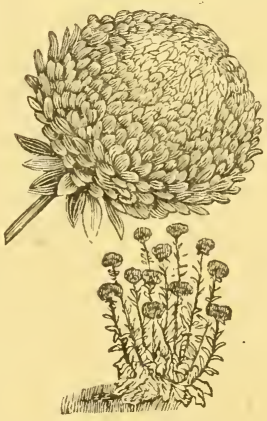

A very hanđisome variety with large flowers, the centres of which are pure white, surrounded with many bright colors, 2 ft. . 10

\section{NEIV ROSE FLOW̄ERED.}

The flowers are large and double, the outer petals finely recurved and the inner ones incurved like a rose. $2 \frac{1}{2}$ feet in height; extra choice mixed 10

ASTER, CROWN.

New Dwarf Bouquet, mixed, (Boltz,) about eight inches high, very constant in height and habit of plant, which is a valuable quality. Extremely pretty, and flowers freely. Splendid mixed............... 10

"Choicest Double German; flowers large, brilliant, very double and regularly imbricated; they are oval in form and somewhat resemble a double; rose mixed colors.... 10 


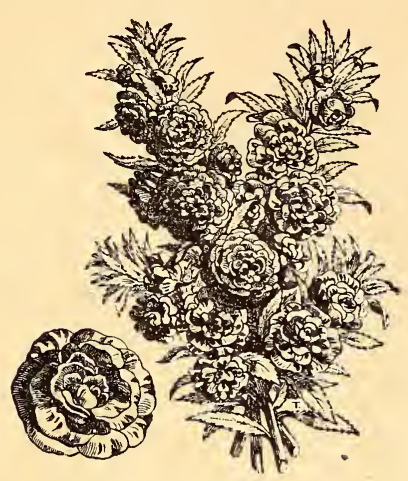

BALSAM.

The Balsam, or Lady's Slipper, is an old favorite, but has been so much improved by cultivation as to be scarcely recognized. Needs good, rich soil, and good cultivation to bring to perfection. Half-hardy annual.

Balsam Camelia; flowered very double and perfect in form, white blotched with varied colors........................... 10

" Double Salferino; striped and streaked with lilac and scarlet on satin white ground........................ 10

BALLOON VINE-(CARDIOSPERMUM.)

Remarkable for its inflated membraneous capsules, and sometimes called Love-in-aPuff. The flowers are insignificant, but the plant is a rapid and graceful climber. Sow in open ground, from 1st to 15th of May, and give plant support to run upon. Tender annual; six feet high.

Cardiospermum, halicacabum, white..... 5

\section{BARTONIA.}

A showy pretty flowering plant, bright metalic-yellow blossoms, about two and a-half inches across. Half-hardy annual.

Bartonia, aurea................... 5

\section{BRIZA.}

(Ornamental Grass.)

Very useful ornamental grass, much sought for winter boquets and wreaths; one foot high.

Briza. Maxima, large.............. 5

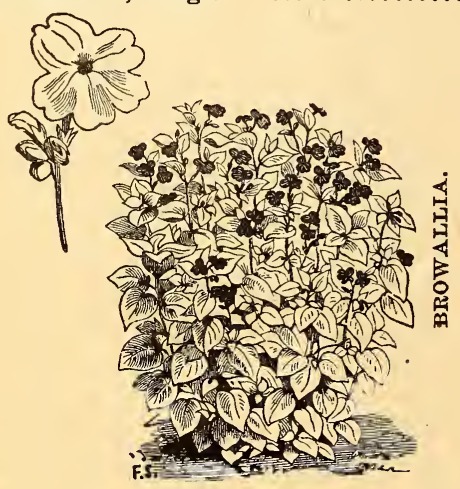

Handsome, profuse-blooming plants covered with pretty blue and white blossoms throughout the whole summer. Half-hardy annnal.

Browallia, Czerviako wski........... 10

BRACHYCOME-(SWAN RIVER DAISY.)

A dwarf growing plant flowering the greater part of the season. Very effective in edgings, beds, or rustic baskets. Requires light, rich soil. Half-hardy annual one foot high.

Brachycome, iberidifolia, blue......... 5

\section{CACALIA.}

A showy plant of easy culture producing beautiful scarlet and golden yellow, tassel-shaped blossoms from July to October. Hardy annual.

Cacalia, Flora's Paint Brush........... 5

\section{CANNA.}

Stately and highly ornamental plant, desirable not only for the beauty of its spikes of flowers, but for its elegant foliage. The leaves are a rich, deep green, three feet long and six inches wide, four to six feet high. Tender annual.

Canna, Indica (Indian Shot).......... 10

\section{CANDYTUFT.}

\section{(Iberis).}

A beautiful and useful plant of the earliest culture, for growing in beds or masses; the white varieties are extensively grown by florists for bouqets; by frequent sowings

they can be had during the winter and summer.

Candytuft, white rocket............. 5 $\operatorname{mixed} . \ldots \ldots \ldots \ldots \ldots \ldots, 5$

\section{CALCEOLARIA.}

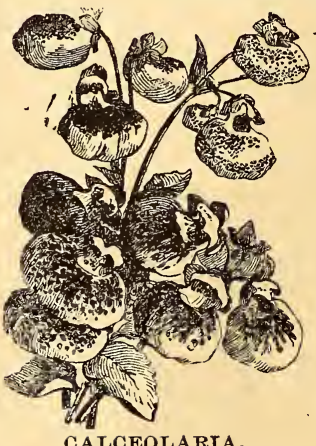

A favorite and universally admired genus, remarkable for their large, beautiful spotted blossums, whi c h are very showy, and from which an al most countless number of hybrids have been raised. They are perennial, are grown in pots in the conservatory, green-h o u s e, and garden; but few flowers are held in greater esteem. They prefer a turfy loam, a mixture of peat and sand, or a rich open garden mold, and are propagated from seed or cuttings. Some of them are herbaceous perennials, others shrubby evergreens.

Calceloaria, Hybrida grandiflora, flowers of immense size ; seed saved from finest specimens. Very Choice..................25 
CALLIOPSIS, OR COREOPSIS.

Producing flowers in nearly every shade of yellow, orange, crimson, red and brown. Hardy annual.

Calliopsis ; mixed colors............ 5

\section{CANARY BIRD FLOWER.}

A beautiful, the charming little canarycolored blossoms bearing a fancied resemblance to a bird with its wings half expanded. Half hardy annual,

Canary Bird Flower............... Io CANTERBURY BELL.-(CAMPANULA MEDIUM.)

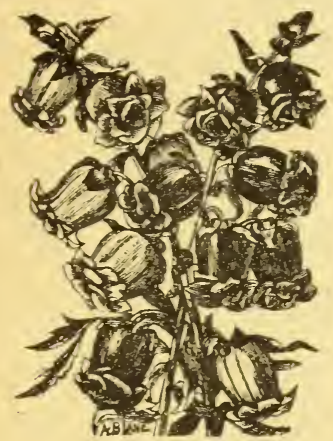

Handsome, hardy biennial, of stately growth, rich color, and profuse bloom. Suc$c$ e eds best in light, rich soil, and should be transplanted two feet apart. Their large, bell shaped flowers are freely produced throughout the summer, and are strikingly effetive.

Canterbury Bell-Double mixed...... 5 CARDUUS.

A strong growing, ornamental genus, very useful in shrubberies and large mixed borders. Hardy biennial.

Carduus Marianus; foliage beautifully variegated; three feet.............. 5

CARNATION AND PICOTEE-(DIANTht:S CARYophyluUs.)

No flower can surpass in delicacy of marking, form, or delicious fragrance, the rich1y hued Carnation. It has always been one of the most esteemed of the florist's collection, and there is no flower more desirable for the garden. The seed will not produce all double flowers, though a good percentage will be double, and of all shades and colors, many being very fragrant. Sow under glass in green-house or hot-bed, and when of sufficient size, transplant two feet apart each way. New and choice varieties are obtained from seed. Half-hardy perennial; one and a half feet high.

Carnation Pink extra fine mixed double Picotee........................ 25

Extra choice double mixed, seed saved from the choicest French, German, Italian, and English stocks. A large proportion of this seed will produce double flowers, and will be appreciated by the florist..... 25

Double mixed, good seed, producing many double flowers of all shades and colors, many being very fragrant.......... Io

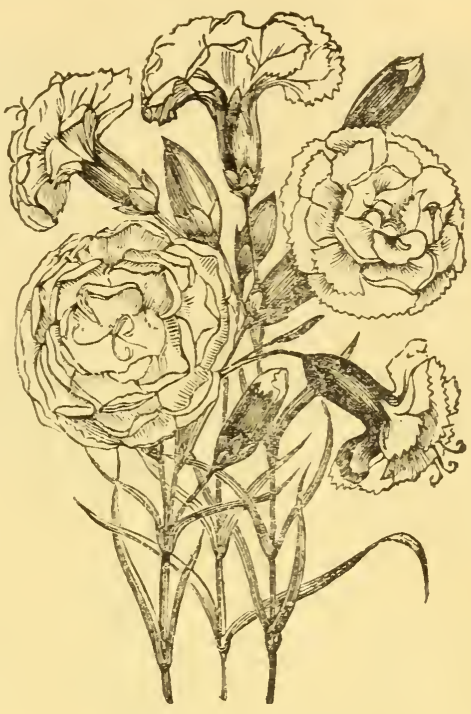

CARNATION PINK.

CATCHFLY-(SILENE.)

An easy growing, free flowering plant, producing dense umbels of white, red and rose pink-like blossoms. The plant is covered with a glutinous moisture, from which flies cannot disengage themselves, hence the name Catchfly. After having been once grown, the seed will sow itself in the ground. Hardy annual; one foot high.

Catchfly mixed colors............. 5

\section{CENTRANTHUS}

Very pretty, free flowering plant, very effctive in beds, ribbons or as an edging, native of Grenada. Hardy annual.

Centranthus, Macrosiphon........... CRYSANTHEMUM.

The tall, doubled flowered, annual Chrysanthemums, are amongst the most showy of summer flowering border plants. Hardy annuals.

Chrysanthemum; mixed varieties..... 5 The Chrysanthemum Indicum and Indicum nanum are the well known varieties for late autumn and early winter flowering; no one should be without them. Half hardy perennial

Chrysanthemum, Indicum.......... ro CLARKIA.

The flowers are very pretty, and of many colors, double and single. Hardy annual; one and a half feet high.

Clarkia, Pulchella................ 5

\section{CLINTONIA.}

Charming little trailing plants, suitable for baskets, pots or rock-work.

Clintonia, Pulchella............. Io 


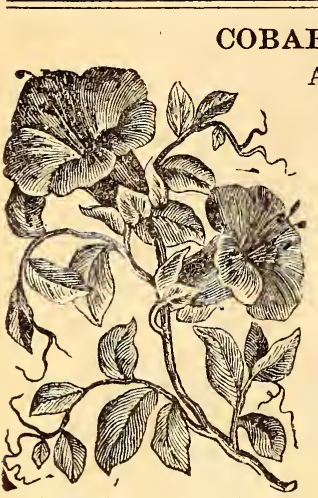

COBAEA SCANDENS.
A fine, rapid-growing climber with handsome foliage, and large bellshaped flowers, green at first, but rapidly changing to a be autiful, deep violet-blue. A plant will run fifty feet in a season, covering a large veranda with handsome foliage and beautiful flowers. Tender perennials.
Cobaea, Scandens................ Io

\section{CONVOLVULUS.}

\section{(Morning Glory.)}

A magnificent class of trailing annuals, some of which produce flowers of wondrous beauty, useful for verandas, lattice, \&c. Half hardy annual.

Convolvulus, Major; mixed......... 5 " Minor; tri-color........ 5

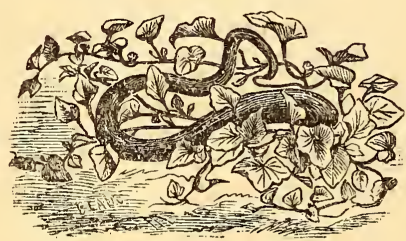

SNAKE CUCUMBER.

\section{CUCUMIS.}

(Ornamenta1 Cucumber.)

A most interesting tribe of plants, remarkable for luxuriance and rapidity of growth, if the soil be rich, is truly marvelous. Treat the same as the cucumber, and train against a wall or trellis, or in any

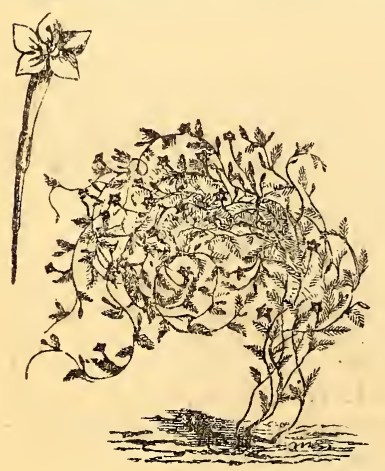
way that may bedesired. Cucumis Flexuos us, comm on $1 \mathrm{y}$ known as the $\mathrm{snake}$ cuc u m ber, is most singularly interesting in its fruit.

Cucumis Flexuosus;'snake cucumber 3 feet..... Io

\section{CYPRUS VINE.}

(Ipomaea Quamoclit.)

One of the most popular of all summer climbers, flowers small, thickly set in a most beautiful dark green foliage; tender annual.

Cypress Vine; scarlet............... 5

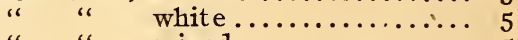

" " mixed $\ldots \ldots \ldots \ldots \ldots \ldots \ldots \ldots, 5$

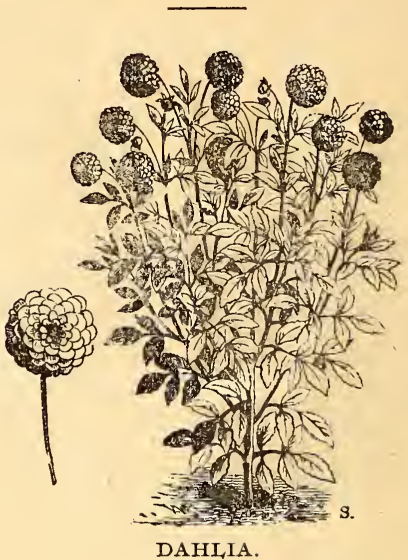

DAHLIA.

New varieties are constantly being produced from seed, some of them exquisite beauty. This noble plant has various heights and colors.

Dahlia ; double-flowering............ I0

DAISY.

(Bellis Perennis.)

Charming little plants for edgings and borders. The flowers are quilled and flat petaled, white, pink, red and variegated. Tender perennial; six inches high.

Daisy ; double, mixed............... Iо

\section{DATURA.}

Large, branching plants, double and single, trumpet-shaped blossoms, yellow, white, lilac and blue and of exquisite fragrance. Roots can be kept all winter in cellars. Tender perennial; three feet high.

Datura ; mixed................... 5

\section{DELPHINIUM.}

\section{(Lark Spur.)}

Plants remarkable for their great beauty, diversity of shades, and highly decorative qualities. The principle colors is blue, shading from the softest celestial to the darkest purple blue, while all are more or less shaded or marked with some other color.

Delphinium ; Hyacinth-flowered....... 


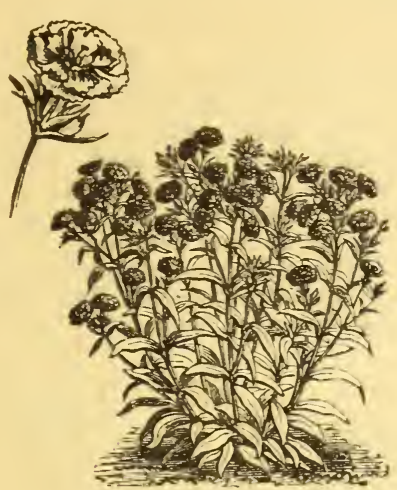

DIANTHUS PINK.

The family of Dianthus is by far the most tu useful of all the biennials and perennials, t and for beauty and variety, cannot be surpassed. The double and single varieties with their rich and varied colored flowers are unsurpassed in beds or mixed borders.

Dianthus China................ 5 " " double............ ro "Chinensis Imperialis; fl. pl. double Imperial pink, a superb variety from China.................. Io

Dianthus Chinensis Laciniatus fl. pl., double Japan pink, rich in hue, very double, deeply fringed petals......... IO

Dianthus Heddewigii Diadematus; double Diadem pink, very regular, densely double, and of all tints from crimsonpurple to deep black-purple. The finest of its species................. 25

Dianthus; best German double flowers, mixed colors.................. Io

\section{DIANTHUS CARYOPHYLLUS.} (See Carnation Pink.)

\section{DIDISCUS.}

Delicate, sky-blue blossoms produced in numerous umbels, or hemispherical heads. Hardy annual; two feet high.

Didiscus Coeruleus............... Io

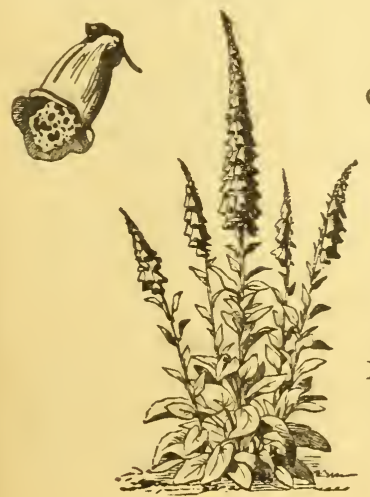

DIGITALIS. (Fox Glove.)

Ornament a 1 plants of much beauty. The blossoms are thimble-sh a ped, purp 1 e, white and spotted. $\mathrm{H}$ a rdy biennial, three feet.

Digitalis; Gloxinia shape flowe rs, $\mathrm{mixed}$ colors.... 5

\section{ESC'HSC:HOLTZIA.}

Finely cut leaves of a glaucous color, and blossoms about two inches in diameter, of many brilliant and showy colors. Sow where the plants are wanted to bloom, as they do not bear transplanting. Thin to six inches apart, half hardy perennial.

Eschscholtzia, Californica; one foot high, mixed colors................ 5

\section{EUPHORBIA.}

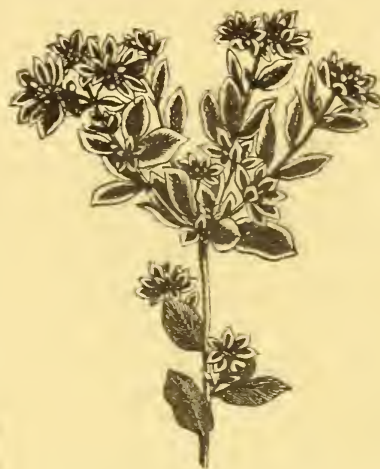

A large family, widely differing in their habits, many varieties beingunworthy of $\mathrm{cu} 1 \mathrm{tiva-}$ tio n. IV e have selected the most useful and beauful variet $y$ for $b$ order and pot culture.

Euphobia, var i e g a t a ; hardy annual; foliage beautifully veined and margined with white; very showy. Sometimes known as Mountain of Snow...................... 5

\section{EVENING PRIMROSE.}

\section{(Enethera.)}

A fine border perennial of easy culturesucceeds best in a light sandy soil.

Evening Primrose; yellow, two feet.... 5

\section{FORGET-ME-NOT. (Myosotis.)}

The Forget-me-not is an old favorite plant, bearing clusters of star-shaped, delicate blue flowers with white and yellow eyes. Hardy perennial; six inches high.

Iyosotis, Forget-me-not, Alpestris; blue Io

\section{GAILLARDIA.}

The first year flowering, and among the gayest ornaments of summer-flowering beds. Hardy annual, one half feet high.

Gaillardia, Picta Grandiflora..........

\section{GERANIUM. \\ (Pelargonium.)}

The constant succession and durability of bloom till frost comes, the brilliancy of the scarlet and other colors, and the exquisite markings of the leaves of some of the varieties render them very desirable. Greenhouse perennial.

Geranium; zonale scarlet.......... Io 


\section{GOMPHRENA.}

(Globe Amaranth.)

A desirable, everlasting, valued for its handsome globular heads of flowers, which, if cut when well matured, will retain their beauty for years. Tender annual; two feet high.

Gomphrena; mixed colors.......... 5

\section{HELIANTHUS.}

(Sun Flower.)

The flowers are really quite attractive. Hardy annual.

Helianthus ; double $. . . \ldots \ldots \ldots \ldots . .5$

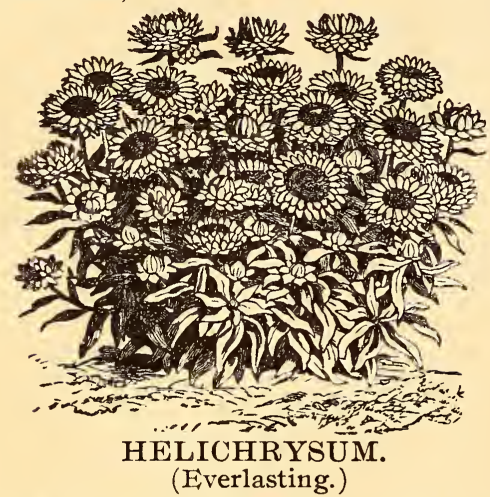

Large, full, double flowers of various colors, from bright yellow to scarlet, shaded and tipped. Sow early in spring, in any good garden soil, and thin the plants to one foot apart each way. Hardy annual; six inches to two feet high.

Helichrysum ; double, mixed........ 5

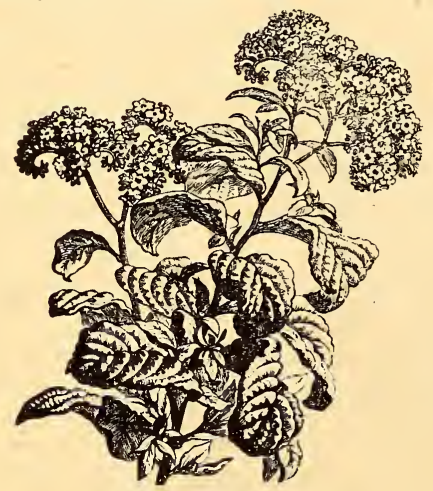

HELIOTROPE.

Highly valued for the fragrance of their flowers and duration of bloom. They succeed in any rich, light soil, and cuttings of the shrubby kind, taken off while young grow readily. Half hardy perennial; one foot high.

Heliotrope ; Peruvianum............. Io

\section{HOLYHOCK.}

For a back ground to a flower garden, perhaps no plant is so useful. The flowers are as double as a rose, of many shades of color, from deep yellow, red, purple to pure white. Plant the seed in June and July in open ground, and in the fall when the plants have made five leaves, transplant to permanent position, three feet apart. The following summer they will bloom. Hardy perennial; five feet.

Hollyhock, double China............. Io

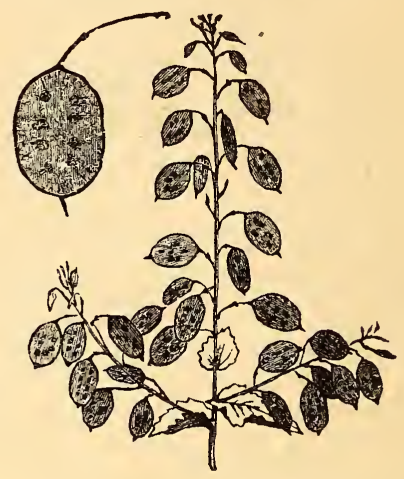

\section{HONESTY. \\ (Lunaria.)}

Early summer free-flowering plants, with silvery tissue seed pods with everlasting flowers for winter boquets. Hardy biennial two feet.

Honesty, Lunaria............... 5

FRENCH HONEYSUCKLE--(HEDYSARUM.

Very handsome, free flowering plants, producing racemes of beautiful, pea-like flowers ; particularly adapted for borders of rock work. Sow in open border in spring. Hardy perennial; four feet high. Hedysarum, coronarium, brilliant scarlet 5

\section{HYACINTH BEAN.}

\section{(Dolichos.)}

Splendid climber, with abundant clustered spikes of purple and white flowers, which are followed by exceedingly ornamental seed pods. Tender annual ten to twenty feet high.

Hyacinth Bean, Dolichos lablab; purple........................ 5

ICE PLANT.

(Mesembryanthemum,)

Mesembryanthemum, Crystallinum (Ice Plant.) Handsome and curious plant for hanging baskets, rock work, vases, and edgings. The leaves and stems are suc- 


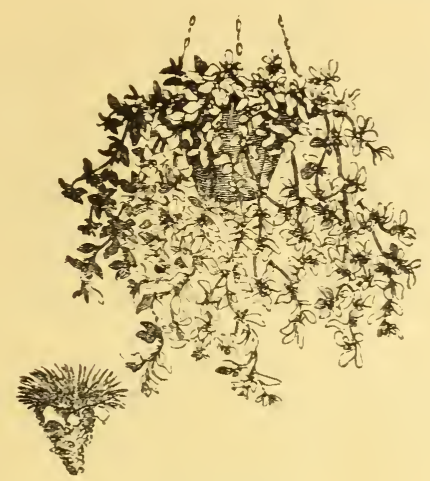

ICE PLANT

culent and fleshy; and appear as though covered with ice crystals, and look like rock candy. Tender annual trailer; six inches high.

Ice Plant, IIesembryanthemum.......

\section{IPOMOPSIS.}

(Tree Cypress.)

A wonderfully handsome plant, with fine, feathery foliage somewhat like that of the cypress vine, and long spikes of beautiful flowers. Sow the seed in August, in a dry situation. Half hardy biennial; three feet high.

Ipomopsis, Tree Cypress.......... 5

\section{JOB'S TEARS.}

(Coix.)

Curious ornamental grass from East India, with broad, corn-like leaves, seeds of a light stale color, valuable for winter boquets with everlasting flowers. Hardy annual; three feet high.

Coix, Lachryma, Job's Tears......... 5

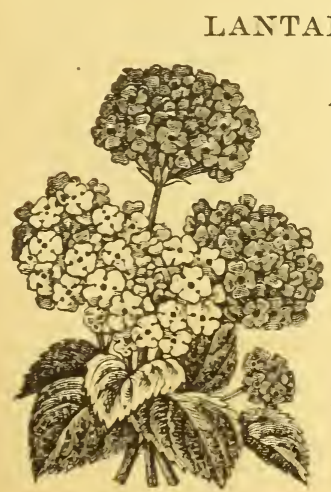

A remarkable handsome, free flowering genus of plants with brilliantly colored flowers, constantly changing in hue; very effective, either for pot culture or bedding.

Lantana ; m ixed colors ....... Io

\section{LOBELIA.}

They are employed as universally in general summer gardens as scarlet geraniums to beds they form a neat and effective edging or rockeries.

Lobelia, Erinus ; mixed colors......... Io

\section{LUFFA, OR VEGETABLE DISH- CLOTH.}

This strange cloth is the product of Papanjay or sponge cucumber (Luffa Acutangula.) It is a sponge-like cloth, in which the seed is enveloped, and ladies say, answers the purpose better than anything yet prepared by art. The fruit is largesome two feet in length-and the

Luffa Acutangula, Vegetable Dishcloth., Io

\section{LUPIN. (Lupinus.)}

A splendid genus of ornamental, beautiful and free flowering garden plants, with long graceful spikes of bloom; colors rich and varied.

Lupinus; mixed................ 5

Cruikshankii............. 5

\section{YCHNIS.}

The flowers are produced in clusters, and are constantly coming out all summer. Hardy perennial, one to three feet high.

Lxchnis, Chalcedonica (London Pride) bright scarlet, two feet high......... ro

\section{MARVEL OF PERU.}

(Four O'clock.)

The plants are large, some of the varieties have beautifully variegated leaves. The flowers are funnel-shaped, white, red and striped, very fragrant, and open about four o'clock in the afternoon, remain open all night, and generally perish before noon the next day. Hardy annual; two feet high.

Marvel of Peru; hybrid mixed....... 5

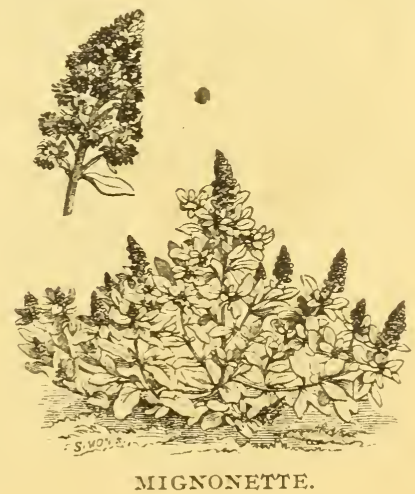




\section{MIGNONETTE.}

A well known hardy annual producing dense, semi-globular heads of exceedingly fragrant flowers, borne on spikes from three to six inches long. Is in bloom nearly the whole season, and the perfume is so fragrant that the whole atmosphere around is perfumed. No garden should be without it. Sow the seeds in the early part of spring, it will be in bloom till killed by the frost. 'Hardy annual, one foot.

Mignonette, (Sweet) reseda odorata......5 large flowering........... MIMULUS.

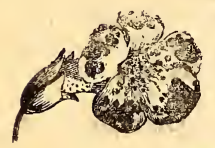

Striking ly han d s o me flow ers of easiest cul$\mathrm{t}$ i vation. Perenni a ls

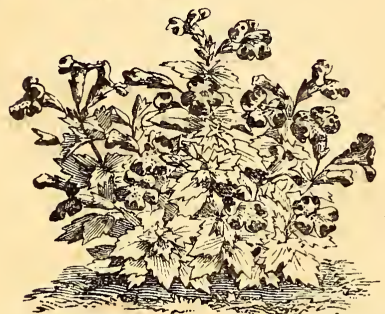

i n g reenhouse, annuals in the open air.

$\mathrm{M} \mathrm{i} \mathrm{m} \mathrm{u} \mathrm{l} \mathrm{u} \mathrm{s}$ Moscha t u s (M u s $\mathbf{k}$ Plant) .. 10

$\mathrm{M}$ i m u l u s (M on key F low er) large beautifully spot-

ted blossoms; blooms first year......... 10 Mimulus, (Tigrinus Duplex) new double

tinged and spotted varieties........... 25 MAURANDIA.

Graceful climber for green-house, parlor, baskets, or out-door purposes. Set out in the border with a little frame to which to attach their tendrils, they will be loaded all the season with rich purple, white and rose, foxglove-shaped blossoms. The seed should be started in hot-bed or green-house, as without artificial heat, they will scarcely flower the first season. They must be removed to a warm place on the approach of cold weather in autumn. Tender perennial climber; six feet high.

Maurandia, Barclayana, purple, rose, white and violet................... 10

" mixed choicest kinds mixed..... 10

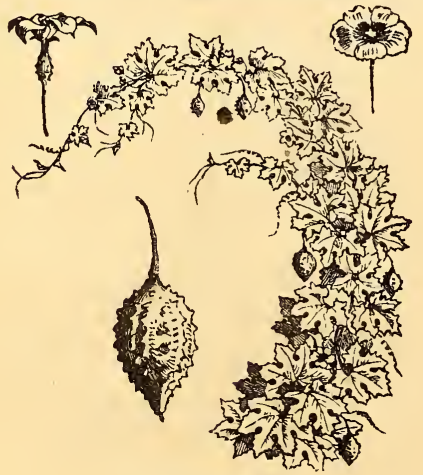

MOMORDICA.

\section{MOMORDICA.}

(Balsam Apple.)

A curious annual climber, with yellow blossoms, and foliage similar to the Canary Bird Flower. The fruit is the chief curiosity, it is egg-shaped, and covered with warty excresences, and when ripe, burst suddenly open 8 sattering its seed, and showing a brilliant carmine-interior.

Momordica, Balsamina (Balsam Apple)... 5

\section{NASTURTIUM.}

(Tropaeolum.)

The colors are very brilliant and of many shades, from scarlet to black.

Nasturtium (Tall ;) mixed............ 5

(Dwarf;) Tom Thumb..... 5

NEMOPHILA.

(Love Grove.)

The flowers are exquisitely colored, biotched and striped. Hardy annual; six inches high.

Nemophila, Maculata, (Love Grove ;) white blotched violet, large flowers..........5

NIGELLA.

(Love-in-a-mist.)

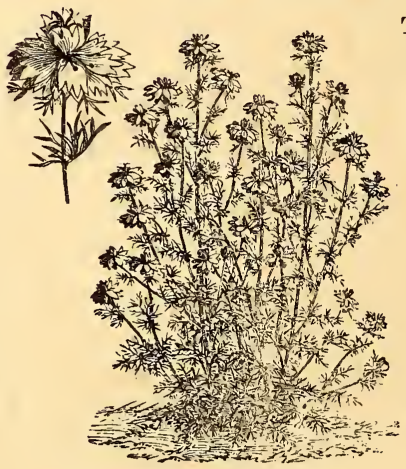

This singular $\mathrm{plant}$ is $\mathrm{known}$ as Lady-in-the Green and Devil-in-a$\mathrm{Bush}$, bec a u s e the bloss om s are partly concea led b y t he abundance of fi $n$ el $y$ cut foliage. Sow the seed in the spring, and thin to one

foot apart. Hardy annual.

Nigella, (Love-in-a-mist) ............ 5

\section{OXALIS}

Very pretty plants with rich, rose-colored blossoms. Halt hardy perennial.

Oxalis, rosea ; rose colored............. 10

\section{PANSY.}

(Heartsease.)

These lovely flowers are favorites with all, not only for their brilliancy and variety of their colors, but for the durability of their bloom. Seed may be sown in open ground in spring or summer, or in hot-bed early in spring. Young plants produce the largest and best flowers. The plants should always occupy a cool, partially shaded situation, and the ground cannot be too rich; coolness and moisture are necessary. Transplant when an inch high. Seed sown in July will blos- 


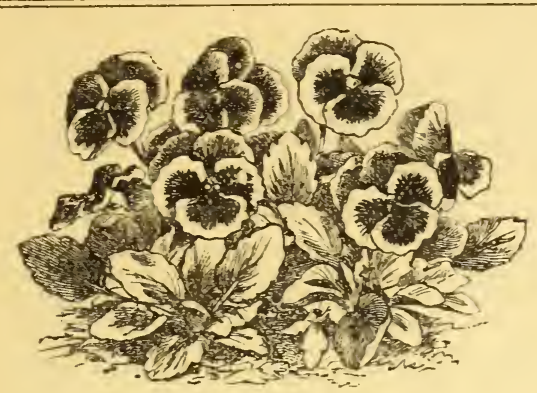

PANSY.

som late in autumn; if sown in October, bloom the following spring. Hardy biennial; four inches high. The following varieties we have imported from the best English, German and French florists, and can recom mend them with confidence. They are saved from the choicest and finest flowers, and comprise all shades of colors, from pure white to King of the Blacks.

Pausy; viola tricolor, mixed........... 10

\section{PANSY.}

FANCY SHOW COLORS.

16 varieties, mixed; Odier or Imperialis, Brown, Red, Auricula Flowered, BronzeColored, Black, Brown, Dark Purple, Pure white and Pure Yellow, King of the Blacks, Purple Bordered Yellow and White, Bright Golden Bronze, Tariegated or Striped, SkyBlue, Emperor William, Lord Beaconsfield.

Pansy; Very fine mixed.............. 25

Trimardeau, an entirely âstinct and beautiful race with flowers of the richest and most varied shades of color. The plants are of a vigorous and compact growth, and the flowers, which possess unusual substance and consistency are each marked with three large blotches or spots. They are of fine form and a size hitherto unattained in this genus-the largest of the Pansy family... 25

German seed mixed.................. 25

\section{PAPAVER.}

Old fashioned flowers, blooming first year from the seed.

Papaver, Bracteatum; double......... 5 " Carnation; double............. 5 ". double white................ 5

\section{PASSION FLOWER.}

A most interesting and well known order of climbers, bearing singularly beautiful flowers. They are the pride of South America and West Indies, where the woods are filled with the species, which climb about from tree to tree, bearing flowers of striking beauty. We have selected two varieties which seem best adapted to our climate, being more hardy than many other sorts.

Passiflora, cærulea, hardy, deciduous climber, with blue and white flowers of remarkable beauty. It is hardy enough to withstand our winters, if the roots are protected with straw, leaves or mulch.............. 10

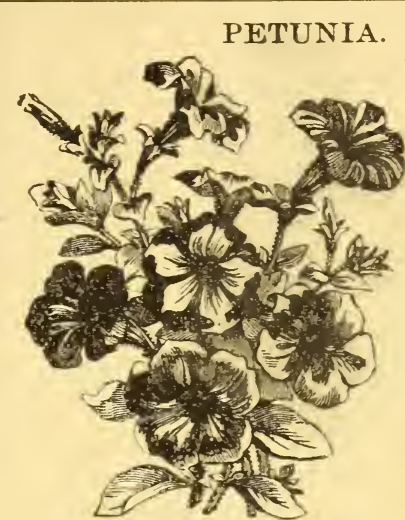

Petunias are unsurpassed, if in $d e \theta d$ equaled for massing in beds. Their richuess of color, duration of bloom and easy culture, will always render them popular. $\mathrm{Th} \theta \mathrm{y}$ will do well sown in open b o r d e r in spring. $[\mathrm{Be}$ careful :not to cover the small seeds too deeply; they like a sandy loam. Tender perennial; one and a-balf feet.

Petunia ; mixed colors............... 5

" spotted and striped........... 10

" double mixed.............. 25

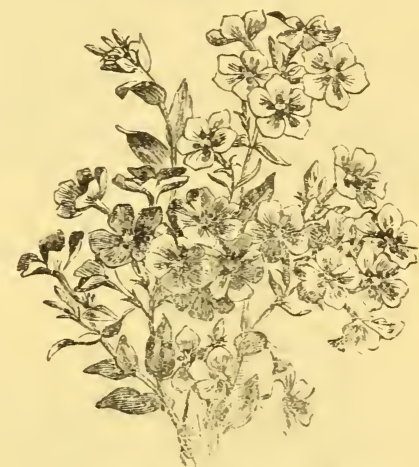

PHLOX DRUMMONDII.

Remarkable for the trilliancy and abundance of their large, terminal Howers, completely hiding the foliage. The blossoms are of many colors-from pure white to deepest purple, eyed and stripert. The seeds can be planted in open ground in autumn crspring. Give good, rich ground and set plants six inches apart each way. Hardy annual; one foot high.

Phlox Drummondii ; mixed ............ 10

Grandiflora ; mixed............. 10

\section{PHLOX PERENNIAL}

The varieties of Perennial Phlox are among the choicest of Howers. They are perfectly hardy, and need no protection.

Phlox, Perennial ; wixed............. 10

\section{PENTSTEMON}

This beautiful class is in continuous bloom from the tinue they are planted out in May until frost. In shape the flowers somewhat resemble the Gloxinia, and are shaded and mottled in white. blue, crimson, scarlet and pink. Half-hardy Perennial.

Pentstemon; fine wixed $2 \mathrm{ft} . \ldots . \ldots \ldots \ldots 10$ 


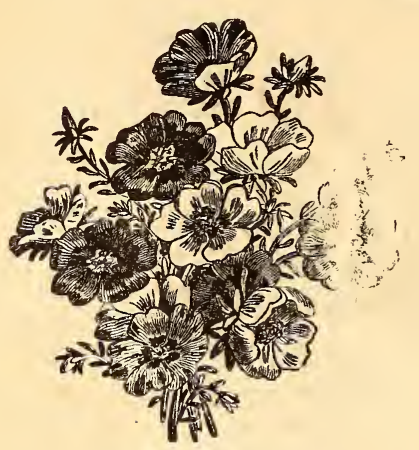

PORT ULACA.

There is scarcely an $y$ flower in cultivation that makes such a dazzling display of beauty as a bed of many-hued, brilliant-colored Portulacas.

Portulaca splendid mixed, single. All col-

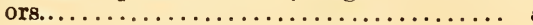

\section{DOUBLE VARIETIES.}

These are unsurpassed for brilliancy of color by any annual grown. Our Double Portulaca is saved from the finest double flowers only, the plauts of which are grown from cuttings, and we believe will produce a larger percentage of double flowers than any other strain offered.

Portulaca Grandiflora fl. pl

" All colors mixed............ 10

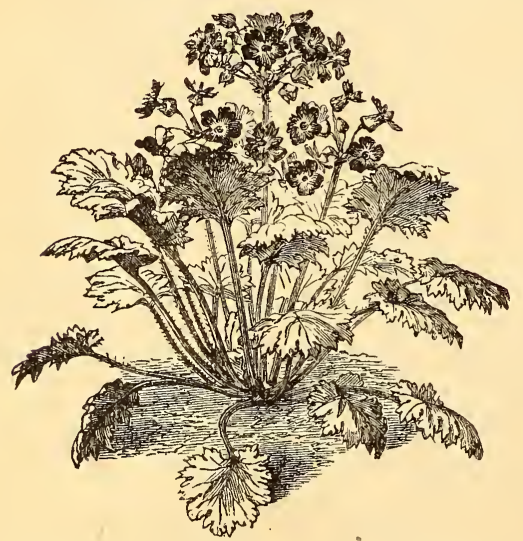

\section{PRIMULA SINENSIS-(CHINESE} Primrose.)

These are perhaps the most desirable of all house blooming plants, and will richly compensate for the little care they require. They are in almost constant bloom all winter, and if the plants be transferred to the border they will blonm nearly all summer. Though perennial, new plants flower more freely, and seed should be sown every year. Sow the seed in sballow boxes filled with good, rich soil, dusting a little fine earth over them; if covered too deeply, or if the seed be wet and allowed to dry again they will not germinate. Transplant into pots, and they will be ready for winter blooming. Tender perennial; six to nine inches high.

Primula, Chinese Primrose............. 10 " Chinensis Primrose; Carmine and

rose varieties.................... 25

\section{PYRETHRUM-(FEVERFEW.)}

Very useful, and universally admired bedding plants, deserving a place in every garden. Sow from December to April, in shallow boxes, in a temperature of $60^{\circ}$. As soon as the young plants can be handled, transplant singly into small pots or shallow boxes, where they may remain until the time of planting out into the open ground in May. Perennials.

Pyrethrum parthenifolium aureum (Goiden Feather,) beautiful, gold leaved bedding plant, retaining its ornamental character until late in autumn. One of the finest acquisitions for geometrical designs; flower white .......................... 10

Pyrethrum, roseum (Insect Powder Plant.) Practical entomologists have long been looking for some effective, safe and cheap insecticide, and now tell us they have found it in the Persian Insect Powder. This is the dried and powdered flowers of the Pyrethrurn Roseum, and is certain death to Plant Lice, Flies, Cabbage Worms and nearly every form of insect life. It is harmless to man, but when diluted with ten times its bulk of flour, kills every cabbage worm or other insect it touches............... 10

\section{RHODANTHE.}

(Everlasting.)

Of all the many varieties of everlastings, the Rhodanthe is the finest and most beautiful. The flowers are of various colors, pure silvery white with yellow disc, rosy-crimson and bright purple, roses suffused with white, \&c. Tender annual one foot high.

Rhodantha, Maculata $. \ldots . . . \ldots \ldots \ldots 10$

\section{RICINUS.}

\section{(Castor Bean.)}

Tall, majestic plants for lawns, with leaves of glossy green, brown, or bronzed metallic hue, and long spikes of prickly capsules of scarlet and green. Tender annual; eight to ten feet high.

Ricinus, Sanguineous; splendid red fruit in clusters, blood red stalks............ 10

Ricinus, giganteus Arboreus (barboni

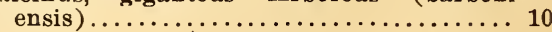

\section{SALPIGLOSSIS.}

Very showy bedding or border plants, with rich-colored, erect, funnel-shaped flowers. The colors are beautifully marbled and pencilled-purple, scarlet, crimson, yellow, buff, blue, and almost black. Bloom from August till October. Tender annual ; one to two feet high.

Salpiglossis, hybrid.............. 5 


\section{SALVIA.}

The Salvia, or Flowering Sage; is a very ornamental plant, flowering in spikes of fiery red, crimson and blue, and continue in blossom in open ground, till frost. Tender annual; one to five feet high.

Salvia, splendens................... 10

\section{SCABIOSA. \\ (Mourning Bride.)}

Handsome flowers in hemispherical heads on long stems, of excellent sweetness, and sometimes called sweet Scabiosa. Tender perennial; one to two feet high.

Scabiosa, Mourning Bride.............. 10

\section{SANVITALIA.}

Very pretty, dwarf, trailing plants, excellent for rock work, borders or edging of beds. Hardy annual; six inches high. Sanvitalia, Procumbens fi. pl.; double flowering and of brilliant golden yellow resembling a miniature double Zenia in form............. 10

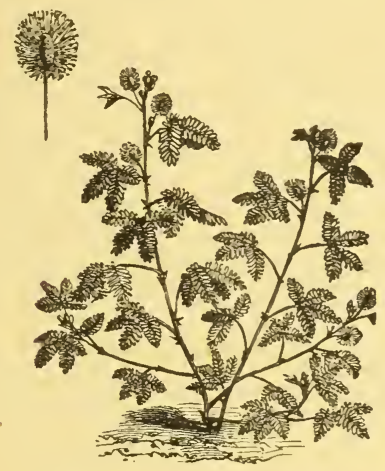

SENSITIVE PLANT.

(Mimosa.)

An interesting and curious plant, with globular heads of pink flowers, well known for the extreme irritability of its leaves and foot stalks, which close and droop at the slightest touch. Tender annual; two feet high.

Sensitive Plant, Mimosa.............. 5

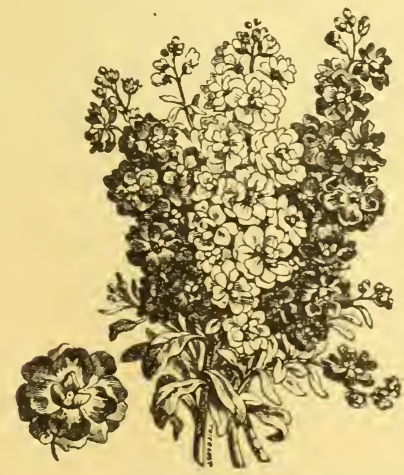

STOCK, DOUBLE GERMAN TEN WEEKS.
STOCK, DOUBLE GERMAN TEN WEEKS.

Grown with such great care that a very large proportion of double flowers are produced from the seed, and of great fragrance and beauty. To have them in bloom early, start in hot-bed, and transplant when small into pots, and turn out in June to open border. The seed may also be planted in the open ground. Hardy annual; one foot high.

Ten week Stocks (Mathiola) .............. 10 " " "German, large double flow-

ering, $\operatorname{mixed} . \ldots \ldots \ldots \ldots \ldots \ldots \ldots \ldots . \ldots \ldots$

SWEET WILLIAM.

(Dianthus Barbatus.)

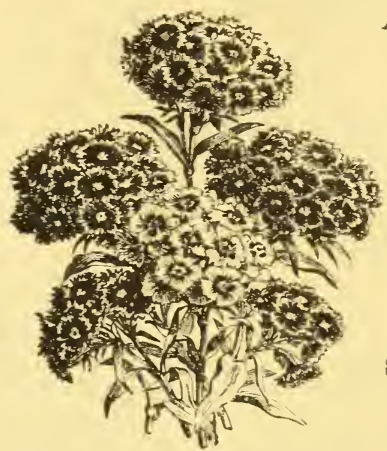

A bed of the finer varieties. Sports into an endless variety of colors, which makes a beautiful sight. $\quad \mathrm{T} \mathrm{h} \mathrm{e}$ plants will bloom several years. Hardy pere n n i l l; one and ahalf feet high. Sweet William, auricula flowe r e d, mix. ed ........ 5

Sweet William, double flowering, mixed.. 10

SWEET PEAS.

(Lathyrus Odoratus.)

Showy, free flowering climber; and deservedly one of the most popular annuals that enrich the flower garden. The flowers are very freely produced, white, red, crimson, purple, black and striped, and quite fragrant. Plant four inches deep, very early in spring -the earlier the better. Hoe the earth towards the vines without ridging, and give support to the vine to run upon. Hardy annual; six feet high.

Sweet Peas, mixed............... 5

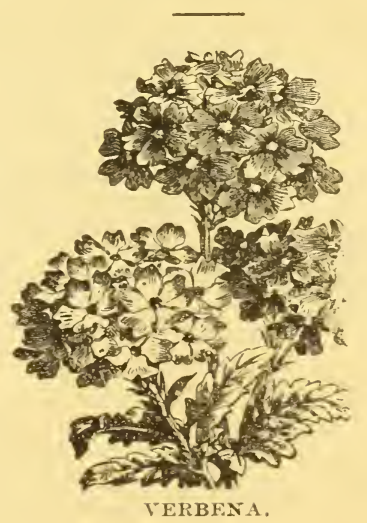

5




\section{VERBENA.}

No plant is more generally cultivated, or more eagerly sought after than the Verbena, and no plant excels it for masses in beds on the lawn. In the varieties may be found every color except yellow. The white is pure, the crimson and scarlet so vivid, and the purple so deep, while the striped are so conspicuous that they are very desirable. They flower perfectly well from seed sown in spring. Tender perennial trailer; one fout high.

Verbena, Italian; striped and variegated. . 10 $\nabla$ erbena, auricula flowered ; various'shades,

all with distinct eye of white or rose.... 10

Verbena, Hybrid.................... 10

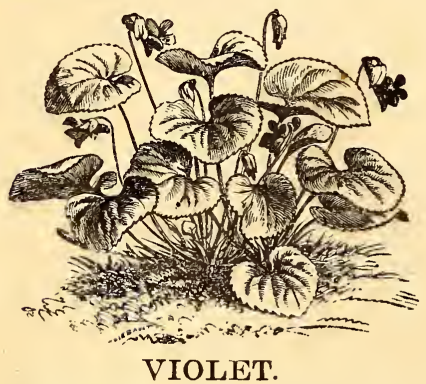

The violet should not be wanting in any garden, on account of its fragrance and early appearance. A single flower will perfume a whole room. The Violet is an emblem of faithfulness. Hardy perennial; four inches high.

Violet, odorata, perpetual sweet scented.... 10

\section{WALL FLOWER.}

\section{(Chieranthus Cheiri.)}

The large, massive spikes of the Wall Flower are veryiconspicuous in beds or borders, and are very useful in making bouquets. They are deliciously fragrant, perfectly double, and combine many shades of color. Remove the pots to the house and they. will bloom all winter.

Wall Flower, double flowering......... 10

\section{WHITLAVIA.}

Charming Hardy Annuals, with beautiful bellshaped flowers, growing freely in any soil.

Whitlavia Grandiflora. Violet blue, $1 \mathrm{ft}$.. 5

\section{WILD FLOWER GARDEN.}

\section{MIXED SEED.}

Embracing many varieties of easy growing and pretty Annual Flowers. Will be found useful for Woodland Walks and Road-sides. Such as the following:-Alyssum, Amaranthus, Celosia, Dianthus, Ice-Plant, Mignonette Pansy, Love-in-a-mist, \&c., \&c.

Wild Flower Garden mixed........... 10

\section{XERANTHEMUM.}

of neat, compact habit, free-flowering and of the easiest cultivation. The leaves are covered with a silvery down, and the flowers are pure white, deep purple and gellow ; single and double. They make fine winter boquet. Hardy annual; one foot high. Xeranthemum, Everlasting ; mixed....... 10

\section{ZEA MAIZE.}

(Striped Japanese.)

An ornamental foliage plant of much beauty, the leaves being beautifully striped with white and green. Half hardy annual from Japan ; six feet high.

Zea Japonica, fol. variegata.......... 5

\section{ZINNIA.}

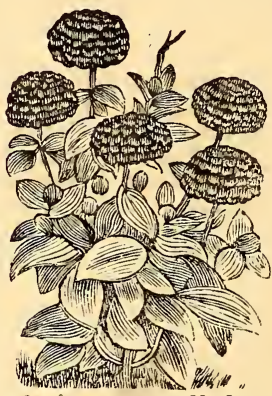

A very showy plant, with large, double flowers, which when fully expanded, from hemispherical heads, become densely imbricated, and might easily be mistaken for dwarf dahlias. The colors run through all the shades of carmine, lilac, scarlet, purple, crimson, yellow, to pure white. If any single blossoms should appear, they should be at once pulled up. Sow the seed early in spring in open ground, and transplant to one and a half feet apart, in good rich soil. Half hardy annual ; one to two feet high.

Zinnia Elegans fl. pl.; finest double varie-

ties ; mixed..................... 10

\section{Collections of Flower Seeds Free by Mail on Receipt of Price.}

\section{HARDY ANNUALS.}

Five Distinct Varieties. Our own selec. tion .......................... 15

Ten Distinct Varieties. Our own selection.......................... 25

Twenty Distinct Varieties. Our own selection.......................... 50

Forty Distinct Varieties. Our own selection ......................... $\$ 100$

\section{BIENNIALS AND PERENNIALS.}

Five Distinct Varieties. Our own selection ........................... 20

Ten Distinct Varieties. Our own selection ........................ 40

Twenty Distinct Varieties. Our own selection ......................... 75

Forty Distinct Varieties. Our own selection.......................\$1 50

The Biennials and Perennials will include five and ten cent packets of flower seeds of our own selection which will give general satisfaction.

The above can be paid in two or one cent Postage stamps being less than one dollar. 


\section{RETAIL PRICE LIST.}

All varieties in SMALL CAP type are of a superior quality.

BEANS-Dwarf or Snap.

plit. pt. qt. peck.

EARLy Red VALEntine. $10 \quad 20 \quad 30 \$ 1.25$ Early White Valentine. . $10 \quad 20 \quad 30 \quad 1.25$

Early Six Weeks' (round seeded.............. $10 \quad 20 \quad 30 \quad 1.25$

Early Six Weeks (long seeded.............. 10

Early Mohawk......... 10

Early Rachel.......... 10

Early Red Eyed China. . 10

Refugee or 1000 to $1 \ldots \ldots 10$

Large White Marrow.... 10

Prolific Tree Bean....... 10

\section{Wax Sorts.}

Early Black Wax.... 10

Early White Wax....... 10

Crystal White Wax.... 10

EARLY GOLDEN WAX... 10

EARLT MONT D'OR..... 10

BEANS-Pole or Running.

Dutch CASE KNIFE.... $10 \quad 20 \quad 35 \quad 1.50$

Horticultural or Wren's

$\begin{array}{llllll}\text { Egg ................... } 10 & 20 & 35 & 1.50\end{array}$

Large White Lima...... $10 \quad 20 \quad 35 \quad 2.00$

Golden Wax Flageo-

$\begin{array}{llllll}\text { LET . ................ } 10 & 20 & 40 & 3.00\end{array}$

German Wax (black seeds) $\ldots \ldots \ldots \ldots \ldots . \ldots 10$

Giant Wax red (seeds). 10

Scarlet Runner......... 10

White Runner........... 10

Southern Prolific....... 10

CORN-Sweet.

Extra Early Tom Thumb 10

EARLy MARbleHEAD . 10

Early Minnesota....... 10

Moore's Early Concord. . 10

Early Triumph........ 10

STOWELls EvergReEN 10

Mammonth Sweet...... 10

Egyptian Sweet ........ 10

Black Mexican......... 10

Adam's Extra Early..... 10

Rice-for Parching...... 10
PEAS-Dwarf and Early.

plst. pt. qt. peck.

Bliss' American Won-

DER................. $10 \quad 20 \quad 40 \quad 2.00$

Early Tom Thumb...... $10 \quad 20 \quad 40 \quad 1.50$

MCLEAN'S LitTLE GEN $10 \quad 20 \quad 40 \quad 1.50$

Carter's First Crop...... $10 \quad 20 \quad 35 \quad 1.25$

Laxon's Alpha.......... $10 \quad 20 \quad 35 \quad 1.50$

BLUE Peter............. $10 \quad 20 \quad 40 \quad 100$

Premium GeM.......... $10 \quad 20 \quad 40 \quad 1.50$

Early Kent.............. $10 \quad 20 \quad 35 \quad 10$

$\begin{array}{lllll}\text { McLean's Advancer..... } & 10 & 20 & 35 & 1.25\end{array}$

Early Philadelnhia...... $10 \quad 20 \quad 35 \quad 1.25$

$\begin{array}{lllll}\text { Dwarf White Marrow fat. } 10 & 20 & 35 & 1.25\end{array}$

$\begin{array}{llllll}\text { Dwarf Sugar............ } 10 & 20 & 40 & 2.00\end{array}$

PEAS-Tall and Late.

Bliss' Ever-BEARING. . $10 \quad 20 \quad 40 \quad 2.00$

BLiss' ABUNDANCE..... $10 \quad 20 \quad 40 \quad 2.00$

CHAMPION OF ENGL AND. $10 \quad 20 \quad 35 \quad 1.50$

Blue inuperial........... $10 \quad 20 \quad 35 \quad 1.50$

$\begin{array}{lllll}\text { White Marrowfat.......... } & 10 & 15 & 25 & 1.00\end{array}$

Tall Sugar............ $10 \quad 30 \quad 50.2 .00$

Add 30 cents per quart for postage by mail.

\section{ASPARAGUS.}

plzt. $0 z, 40 z$.

Conover's Colossal........... ऽ 10 -

BEET.

Early Dark Red Egyptiar $5 \quad 10 \quad 25$

DEWING'S IMPROVED......... $5 \quad 10 \quad 25$

Eclipse (New).............. $5 \quad 10 \quad 25$

Early Turnip Bassano......... $5 \quad 10 \quad 25$

DARK RED TURNIP........... $5 \quad 10 \quad 25$

Long Smooth Red............ $5 \quad 10 \quad 25$

French White Sugar............ $5 \quad 10 \quad 25$

Mammoth Long Red......... 51025

BROCCOLI.

Early Purple Cape.......... $5 \quad 10 \quad 25$

BORECOL OR KALE.

Dwarf German Greens....... $5 \quad 10 \quad 25$ 


\section{CABBAGE-Early Varieties.}

plkt. Oz. 40z.

Early Etampes............ $5 \quad 20 \quad 60$

Little Pixie................ $5 \quad 20$ -

Early York.................. $5 \quad 15 \quad 40$

Early Large York............ $5 \quad 15 \quad 40$

EARLX WINNINGSTADT........ $5515 \quad 50$

EARLy Jersey WAKEField. $5 \quad 301.00$

Early Flat Dutch........... 5 $20 \quad 60$

Early French Oxheart......... $55^{\circ} 20 \quad 60$

Early Schweinfurt............ $5 \quad 20 \quad 60$

EARLy Summer, Henderson's $5 \quad 2060$

Early Drumbead............. $5 \quad 20 \quad 60$

Late Varieties.

Premium Flat Dutch....... $5 \quad 15 \quad 50$

Marblehead Mammoth......... $5 \quad 20 \quad 75$

FILDERKRAUT ................ $5 \quad 5 \quad 20 \quad 75$

Large Late Drumhead........ $5 \quad 15 \quad 50$

FotLER's BRUNSWICK DRUM-

HEAD .................. 5 $520 \quad 60$

Stone Mason Drumbead........ $5 \quad 20 \quad 60$

Large Bergen............... $5 \quad 20 \quad 60$

Red Dutch Cabbage........... $5 \quad 20$ -

SURE HEAD................ $5 \quad 20 \quad 75$

\section{Savoy Varieties.}

Early Dwarf Ulm........ $5 \quad 20$

IMPROVED AMERICAN...... $5 \quad 50$

Early Netted Paris......... $5 \quad 30$

Late Drumhead............ $5 \quad 20$

\section{CARROT.}

Early Half-long............ $5 \quad 10 \quad 25$

Long Orange................. $5 \quad 10 \quad 25$

\section{CAULIFLOWER.}

Extra Early Paris........ 5 75

Early Erfurt............. $5 \quad 1.00$

EARLy SNowball....... 53.00

Lenormand's Short Stem... - . 50

\section{CELERY.}

BOSTON MARKET........... $5 \quad 20$

Giant White Solid........... 520

Dwarf White Solid.......... $5 \quad 20$

DWARF LARGE RIBBED

White Solid........... $5 \quad 20$

HeNDERSON's Rose......... 540

Dwarf Golden Heart......... 520

HeNderson's White PLUME 540

Sandringham White........ $5 \quad 20$

Turnip Rooted............... 520

Celery Seed for Flavoring.... - 10 CUCUMBER.

Early Russian............... $5 \quad 10 \quad 30$

Early Green Cluster............ $5 \quad 10 \quad 30$

EARLY SHORT GREEN, or

-Early Frame............. $5 \quad 10 \quad 30$

EARLY WHITE SPINE........ $5 \quad 10 \quad 30$

Boston Pickling, or Green Pro-

lific.................... $5 \quad 10 \quad 30$

Improved Long Green......... $55 \quad 5 \quad 10 \quad 30$

Gherkin or Burr............ $5 \quad 20 \quad 80$ CRESS OR PEPPERGRASS.

Cress Curled................ $5 \quad 15$ -

Cress, Water True........... 540
EGG PLAN'T.

plat. 0z. $40 z$.

Long Purple.............. 5 25 -

NEW YORK IMPROVED PURPLE 550 ENDIVE.

Green Curled............... $5 \quad 20 \quad 60$

Broad Leaved Batavian....... $5 \quad 20 \quad 60$ KOHL RABI.

Early White Vienna........ 520 -

Large Purple.............. 520 -

LEEK.

London Flag............. 520 -

LETTUCE.

HANSON (best)............ $5 \quad 15 \quad 50$

Early Curled Silisia............ $5 \quad 17 \quad 40$

Early Curled Simpson......... $5 \quad 15 \quad 40$

Tennis Ball................. $5 \quad 15 \quad 40$

Boston Curled............... $5 \quad 1540$

Large Drumbead............ $5 \quad 15 \quad 40$

New Perpetual................. $5 \quad 25 \quad 80$

California Fringed.............. $5 \quad 25 \quad 80$

Green Winter............... $5 \quad 15 \quad 40$

MARTYNIA.

Probascidea................ $5 \quad 25 \quad 80$

$$
\text { MELON-Musk. }
$$

Jenny Lind................ $5 \quad 5 \quad 10 \quad 30$

Cassaba........................ $5 \quad 10 \quad 30$

Large Yellow Canteloupe...... $5 \quad 10 \quad 30$

Green Nutmeg............... $5 \quad 5 \quad 10 \quad 30$

MONTREAL MARKET.......... $5 \quad 5 \quad 10 \quad 30$

\section{MELON-Water.}

Early Phinney............... $5 \quad 10 \quad 30$

Striped Gypsy............... $5 \quad 10 \quad 30$

Cuban Queen................ 5510 30)

Mountain Sweet............... $5 \quad 5 \quad 10 \quad 30$

Mountain Sprout.............. $5 \quad 10 \quad 30$

Ferry's Peerless............... $5 \quad 10 \quad 30$

60 Citron ........................ $5510 \quad 50$

KoL B GEM................. $5 \quad 10 \quad 30$

MAMMOTH IRON CLAD ....... $5510 \quad 30$

OKRA.

Dwarf White.............. $5 \quad 10 \quad 25$

Tall White................. $5 \quad 10 \quad 25$

\section{ONION.}

EARLy RED.............. $5 \quad 20 \quad 60$

$\begin{array}{llll}\text { White Portugal, or silver skin } 5 & 30 & 1.00\end{array}$

Large White Globe.......... $5 \quad 25 \quad 80$

Yellow Danvers.............. $5 \quad 20 \quad 60$

Large Red Wethersfield..... $5 \quad 5 \quad 20 \quad 60$

New Queen.................. $5530 \quad 1.00$

Large Giant Rocca.......... $5 \quad 20 \quad 60$

Yellow Dutch............... $5 \quad 20 \quad 60$

PARSLEY.

Double Curled.............. $5 \quad 10 \quad 30$

New Ferned Leaved............ 5 5 $10 \quad 30$

PARSNIP.

Long White Dutch.......... $5 \quad 10 \quad 20$

Hollow Crown................ $5 \quad 5 \quad 10 \quad 20$ 


\section{PEPPER.}

plat. oz. $40 z$.

Sweet Bell or Bull Nose...... 5 2060

Long Red Cayenne........... $5 \quad 2060$

DWARF GoLDEN DAW

Sweet Mountain, or Mammoth. $5 \quad 20 \quad 60$ PTIMPKIN.

Large Cheese (Sweet)......... $5 \quad 1025$

Cashaw (crooked neck)........ $5 \quad 10 \quad 25$

Sweet Potato Pumpkin........ $5 \quad 1025$ RADISH.

Early White Turnip......... $5 \quad 10 \quad \cdot 25$

Early Scarlet Turnip.......... $5 \quad 1025$

Early Scarlet Turnip, (white)

tipped)................. $5 \quad 10 \quad 25$

EARLY LONG SCARLET...... $5 \quad 10 \quad 25$

FrENCH BREAKFAST........ 50.1025

Olive-Shaped Scarlet.......... 551025

Black Spanish Winter........ 5 1025

Scarlet China Winter......... $5 \quad 1025$

BeCkert's Chartier....... $5 \quad 1025$

RHUBARB, OR PIE PLANT.

Linnseus ................ $5 \quad 1025$ SALSIFY.

Oyster Plant.............. 51030

SPINACH.

Round Summer............. $5 \quad 10 \quad 25$

\section{SQUASH.}

Hubbard.................. 5 1030

Patty Pan................. 51030

Marblehead................. 5 1030

White Pine Apple........... 51030

Mammoth Chili............. $5 \quad 20 \quad 75$

\section{HARDY BULBS.}

Nothing will give more beauty and pleasure for a small amount of money than a display of Hyacinths, Tulips, etc. They are easily planted, care for themselves duriug the winter, and are the first harbingers of spring to show that winter is gone. They can be readily lifted after blooming to make room for summer blooming flowers.

Hardy Bulbs can be planted any time between September 15th and freezing. They should be lightly protected with brush, evergreen boughs or straw.

\section{HYACINTHS FOR FALL PLANT- ING.}

These can be had in double white, red, blue and yellow. Plant 4 inches deep.

For forcing in pots or glasses the named varieties are the best; they can be had in bloom in January if potted in October. Plant two bulbs in a five-inch pot.

\section{TULIPS.}

They have a long period of bloom in the different sorts, and are of exceeding brilliancy of color. Plant about two inches deep. Single and Double, best varieties.
TOMATO.

pist. $0 z .40 z$.

Canada Victor............ 52060

Early Smooth Red............ 52060

Hathaway's Excelsior........ $5 \quad 2060$

Red Trophy............... $5 \quad 20 \quad 60$

Golden Trophy.............. $5 \quad 20 \quad 60$

Paragon................... $5 \quad 20 \quad 60$

Livingstone Perfection... 52060

LIVINGSTONE FAVORITE...... $5 \quad 52060$

THE MIKADo or Turner $\mathrm{Hy}$ brid................... $5 \quad 25 \quad 75$

\section{TURNIP.}

RED TOP StraP LEAF...... $5 \quad 10$ 25

White Top Scrap Leaf........ $5 \quad 10 \quad 25$

White Globe Pomeranean..... $5 \quad 10 \quad 25$

Yellow Aberdeen............ $5 \quad 1025$

Large Yellow Globe.......... $5 \quad 1025$

\section{TURNIP RU'TA BAGA.}

Laing's Improved........... 51025

Carter's Imperail............. $5 \quad 10 \quad 25$

Sweet German.............. $5 \quad 1025$

Purple Top or American..... $5 \quad 10 \quad 25$

POT, SWEET HERBS, \&C.

Sage................. $515-$

Saffron................ 515 -

Summer Savoy............ 5 10

Basil, Sweet............. 5 - -

Marjorum, Sweet..........5 - -

GRASS SEEDS.

Fine Mixed Lawn.......... 15 -

Hyacinths, Single Red, -White. Blue, Yellow, Mixed.

1 for 10 cts.; 3 for 25 cts.; 1 dozen, mixed, 75 c.

Hyacinths, Double Red, White, Blue, Yellow, Mixed.

1 for 10 c. 3 for 25c. 1 doz. 85c. Single and double, mixed, 75cts.

Tulips, Early Single Red, White, Mixed.

1 for $2 \mathrm{c} ; 1 / 2$ doz. $10 \mathrm{c}$; 1 dozen, mixed, 15 cts.

Tulips, Early Double Red, White Red and Yellow, Mixed, Late Mixed.

1 for 3 c. 2 for 5 c. 1 doz. 25c. Early and late mixed.

Crocus, Large Yellow, Purple, White, Striped and Variegated, Mixed.

1 for 2 c. $1 / 2$ dozen, 10 cts.; 1 dozen, mixed, 15 c.

Snowdrops, Single White, Double White.

1 for 2 c.. $1 / 2$ doz. 10c. 1 dozen, mixed, $15 \mathrm{cts}$.

For spring planting Gladiolns and Tuberose Bulbs at 5 cts. each or_50 cts. per dozen. 
This book is a complete reculy reference library for farmers and housekeepers, being tilled with useful facts, lints and suggestions upon all suljects pertaining to rural and domestic affuirs, ernbracius the results of experiment and research by scientitic and practical men and women in all civilized countries. It contains the cream or substance of more tiran a dozen ordinary asricultural and kind ever sold at less than six dollars. It is a book to be consulted every day in any cmersency, and to be read at all times with interest and profit. It is such a book as every farmer and honsekeeper needs and ourht to have, supilying the universal want of a reliable cominsellor upon every to small cost cvery weck in the year. The work is protusely illustrated, and is divided into two general heaups half the book. These are again subdivided into a number of departments. Ve append a partial summary of the contents:

Rural Architecture.-This department comprises designs and plans for country houses, cottages, barns and other outbuild. ings, with valuable suggestions to those iutending to build.

ings, with valuable suggestions to those iutending to build. and fenees, for farm aud lawn, oruameutal and cheap, with plain

directions for their construstion, are le:e giren.
Fleld Crops. - This department contains valuable hints and useful suggestious regarding the culture of whent, corn, potatoes, hay, roots, tobacco, etc., treats of plowing, seeding, hoeing, weeding and harvestiug, the diseases and inseet or other ene

crops and the best methods of combating them, etc., etc. cr gre:ter iutportance, is fully treated. Information is given as to the value of each of the rarious substances in their application to differeut crops and qualitiesof soil, likewise as to home manufacture and production of fertilizers, etc., etc. mation regarding the successlul growing of asparagus, celery, cauliflower, tomatoes, onions, squashes, nielons, cucumbers, cabbages, parsely, spinaeh, beans, beets, radishes, musliroons, etc. directions for destroring garden pests, and much other matter. Orehard and Vineyard. - Under this heading we have a
complcte fruit book, wich a vast amount of useful information for complcte iruit book, with a vast amount of useful in ormation for growers of peaches, plums, pears, apples, cherres, quinces and grapes; directions for pruning and grafting, care and mand and for curing disease and erndicnting pests, etc., etc.

Small Fruitg.-This department gives directions for the successful cultivation of strawberries, raspberries, blackbcrrics, whortleberries, goosebcries, currants and cranberries, ennmer ing the expcriences of the most successful small fruit culturists. Life Stock.-More than fifty pages are allotted to this impor$\tan t$ subject, and herein will be found information of great value regard peculiar to the and of anruly and vicious habits, for the conpeculiar to them and of all unruly and vicious habits, for the

The Poultry Yard.-This department gives the fullest in. formation regarding the care and management of poultry, tells how and what to feed, how to make incubators, how to raisc artificiallyhatched chickens, how to cure all diseases of poultry; gives num. erous designs and plans for approved poultry houses, coops and yards, directions for marketing, prcserving eggs, caponizing, etc. The Dairy, - Uuder this heading is given the fullest information regarding butter making and dairy farm

The Aplary. - The care and management of bees is fully treated in this department, aud to those interested in this profit able pursuit, the information here given will be found invaluable. Farm Implements.-Directions for making numerous useful and labor-saving utensils, all of which are unpatented and may be easily made, are here given. Among them are harrows, hay elevators, weeding implements, tread powers, corn-markers,
clod crushers, post drivers, plow attachments, corn shellers, road

sorapers, snow plows, bag holders, etc., etc. Around the Farm.-The topics treated in this department
are such as could not be properly classificd elsewhere. Amoug then are ensilage, drainage, lawn making, painting, whitewashing, smoke houses, ice houses, cisterns, cellars, traps, tanning hides,

curing meats, and hundreds of other m
one of the most valuable in the book.

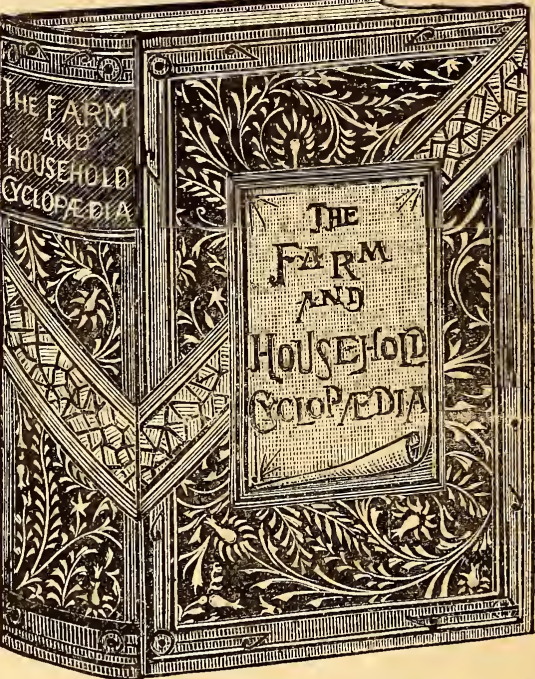

Cooking Reclpes. - This department occupies seventy pages, and is a conmplete and most excellent cook book. It comprises a large number of recines for breakrast dishes, soups, neats and jellies and prescrvcs, puddings, pies, fancy dishes, cakes, ice cream, es, summer drinks, and confectionery.

Ladies' Faney Work.-Herein are given designs and directions for making many beautiful things for the adornment of tidies, embroidery designs, rugs, work bnskets, hassocks, pillow ghams, clothes brush holdcrs, scrap bags, pin cushions, pen wipers, music stands, brush holders, scrap bags, pin cushions, pen wipers, ottomans, sofa pillows, wall pockets, etc., etc.

Florieulture.-The thirty pages allotted to tbis subject will
Fing be found of great interest and value to every lady who cultivates flowers. Information is given as to the best method of propagating and treating all the different plants, the curc of disease and eradication of insect pests, likewise dircctions for making many beautiful floral and other deviccs, for winclow gardening, etc., etc.

The Ilome Physician. - The filty pages allotted to this department form a complete mecitcal book, and are quite as valuable as nine-tenths of the books of this kind sold. Herein are given simple yet reliable home remedies for all the common complaints to which mankind is suliject, and the information thus gaiued will be

The Tollet.-The tecth, hands, hair, breath, lips, skin and complexion are treated under this heading; directions are given for removing all blemishes from and beautifying the same, likewise recipes for various kinds of perfumery, etc., etc.

The Laundry.-Directions for washing all kinds of fabrics and garments, for makiug washing machines, clothes bars, clothes sprinklers, washing fluids, starch enamels, and much other infor tion of great value will be found in this department.

IInts and Helps. - This department is in itself a complete cyclopedia of valuable and useful household in formation, worth with facts, hints and suggestions upon such a variety of topics that we have not space to enumerate cven a portion of them.

Only a very small portion of the contents of this book are enumerated above. It is a vast storehouse of useful facts, hints and suggestions of the utmost value to farmers and housekee pers, and no man who has a home and an acre or more of land can afford to be without it. The publishers know fall well that farmers are a class who have no money to waste upon luxuries, and are equally well aware that the purchase of this book will be to them the most profitable of investments. While other books of this character are sold for $\$ 6.00$ and $\$ 10.00$, for all practical purposes they are no better than this. The book meets a universal want, and should find its way into every rural home.

THE FARM AND HOUSEHOLD CYCLOPADIA is a large and handsome book of 544 pages, 12mo, printed upon fine paper, and elegantly bound in cloth, embellished with artistic designs in black and gold. It contains Two $\mathbf{H}$ indred and Farty-Nine illustrations, the original cost of which was nearly $\$ 5,000$. The book will be sent by sold at $\$ 1.50$ and $\$ 2.00$, and its contents are worth the weight of the book in gold to every farmer and liousekeeper.

1. Thirty (30) cents worth of Flower Seeds will be given free wlth the book for One Dollar.

2. The above book offered free as a Premium. By sending two dollars with the order you can select flower seeds amounting to two dollars of your own selection in 5,10 and 25 cent packets mailed free with Premium Book.

3. Premium as above free by sending three dollars with the order when you can select vegetable seeds amounting to three dollars in five cent packets mailed free with Premium Book, but if Peas, Beans and Corn are wanted with the vegetable seeds amonnting to said three dollars they can be sent by Express or Freight as requested 


\section{F $E$ OQW ER}

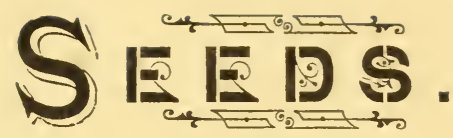

\section{Four Collections No. I, 2, 3 and 4 .}

No. I, 2 and 3, each Collection ro varieties. Any one of the three Nos. for 25 cents or five Packets of No. I, 2 or 3 for $\$ 1.00$.

No. 4 Collection, I 5 varieties for 50 cents. One of each collection No. I, 2, 3 and 4 for \$I.OO.

\section{Collection No. I. Ten Varieties for 25 cts.}

ASTER, Choice Double German; resemble a double rose, mixed colors.

ALYSSUM, Sweet, White and fragrant.

ADONIS FLOWER; The flowers are of a brilliant red color.

AGROSTEMMA, Rose of Hearen, White center and rose colored.

AMARANTHUS, Joseph's Coat; Foliage plant in perfection first season.
ANAGALLIS, Grandiflora. For basket or rock Work, mixed colors.

CANDYTUFT. All varieties, look best in beds or masses.

DIANTHCS PINK ; Choice German, double flowers, mixed colors.

MIGNONETTE, sweet large flowering, exceedingly fragrant.

PANSI, fancy colors, flowers large and markings of the richest colors, in bloom the first season.

\section{Collection No. 2. Ten Varieties, 25 cents.}

BALsAM, Camellia-flowered; very double mixed colors.

AGERATUM, Blooms constantly all sum mer.

AMARANTHUS, Ornamental-leaved plant, foliage brilliant red.

ANTIRRHINUM, Large, curiously shaped flowers, mixed colors.

CLARKIA. The flowers are very pretty and of many colors.
DIANTHUS, Double Japan Pink rich in hue and leeply fringed petals.

HIBISCUS, Pretty foliage and large, showy blossoms.

TEX WEEK STOCK, German double and large flowering.

SWEET WILLIAMS, Far surpassing the perennial Phloxes.

PANSY, Fancy colors mixed in bloom first season.

\section{Collection No. 3. Io Varieties for 25 cts.}

CARNATION PINK; No flower is more de- I ICE PLANT. The leaves have the appearsirable for the garden.

CANDYTUFT; All varieties look best in beds or masses.

CYPRESS VINE; A beautiful fern-like foliage plant, small flowers.

ESCHSCHOLTZLA; Finely cut leaves and striped fiowers.

GOMPHRENA, Everlasting; Globe shaped, red, white and variegated. ance of being covered with ice.

MIMOSA, Sensitive plant, leares closing if touched or shaken.

PETUNIA. The brilliancy of its colors, fringed and varigated.

PHLOX DRUMMONDII. These flowers are of extreme beauty.

PANSY, Flowers large, perfect in form and markings of the richest colors, in bloom the first season. 


\section{Collection No. 4. 15 Varieties for 50 cts.}

PANSY, Choice German mixed, large Flowering.

PHLOX DRUMMONDII; Saved from the best varieties mixed.

ANTIRRHINUM SNAPDRAGON; Iarge curious shaped flowers.

ALYSSUM-Sweet; Flowers pure white and very fragrant.

ASTER, For beauty the double Asters stands unrivalled.

CARNATION, Double Pink; No flower can surpass its richly hued markings in so many colors.

CYPRESS VINE; A beautiful fern-like foliw. age plant, small flowers.
DIADEM PINK; Beautiful double fringed flowers of varied tints.

DIGITALIS FOXGLOVE; Gloxinia-shaped flowers, very ornamental.

HELICHRYSUM ; Everlasting flowers, large double mixed.

MYOSOTIS, For-get-me-not; star shaped, blue flowers with white and yellow eyes.

MIGNONETTE ; Large flowering, very fragrant, in bloom nearly all summer.

PORTULACA; Double rose flowered, scarlet white, variegated, \&c.

PRIMULA; Chinese Primrose, Fringed rose and white mixed.

VERBENA; Extra tine Hybrids mixed, including Italian striped.

Collections No. I, 2, 3 and 4. Each.Collection and each Packet having illustrations and directions printed on each packet of the named varieties.

We cannot make a single change in these collections and no other varieties can be sold or substituted at these low rates.

Remittance may be made by Post Office Order or Postal Note. If less, one dollar payments can be made in Postage stamps. The cash must always be sent with the order.

\section{J. M. PHILIPS \& SONS,}

$$
\text { Mercersburg, } P a \text {. }
$$

We are also Agents for the "Planet Jr." Farm and Garden Tools. S. L. Allen \& Co., Manufacturers.

\section{Testimonials.}

WESTMinster, MD., JUNE 8th, 1886.

TO WHOM IT MAY CONCERN :-The undersigned citizens of Westminster and its vicinity in Carroll' County, Md., hereby certify that for several years past, they have been using 'PooL's INSECT POWDER," manufactured by him, in this place, and with the most satisfactory results ; we have no hesitancy in saying, that while perfectly harmless to human life it is certain death to insect life, such as the Cabbage Flea and Worm, Currant Worm, Cucumber and Pumpkin Bug, Potato Bug, and all manner of insects on Flowers and Vegetables.

\section{Respectfully, \&c.,}

Wm. A. McKellip, Gustavus W. Crapster, Benjamin W. Buckingham, Chas. H. Baughman, Rev. Charles A. Reid, Harry C. Keefer, Dr. Daniel F. Shipley, Lawrence Zepp, H. B. Albaugh, John Marsh, Geo. A. Miller, Ex Clerk of Circuit Court; Rev. Geo. W. Heyde, Wm. B. Thomas, Benj. W. Bennett, J. K. Longwell, Isaac C. Baile, John T. Lynch, Sheriff; Dr. J. W. Hering, G. R. Gehr, Ephraim Lindsay, W. H. Vanderford, Rev. H. W. Kuhns. F. K. Herr, E. O. Grimes, J. W. Smith, Geo. W. Albaugh, H. E. Morelock.

I have heard it spoken of in the most flattering terms. Rev. John Gloyd, P. P.

The above Insect Powder is put up in 15 cent packages with full directions for the use of it. 


\section{The "PLARE.T. IR."}

\section{FARM AND GARDEN TOOLS}

This very complete line of Tools is popular beyond any similar goods we have ever sold; they have outlived every competitor, and though already standing unrivalled, all of them have been either entirely remodelled or greatly improved for the coming season's work. SEND FOR THE 1888 CATALOGUE, 40 Illustrations, Full Descriptions: FREE.

\section{бhe "巳laner dR." Ro. 2 Seed Drill.}

Sows all garden seeds accurately at any desired thickness or depth, opening, dropping covering, rolling down and marking the next row all at one passage in the most perfect and reliable manner. It holds $21 / 2$ quarts. It has no cams, levers, brushes, cogs, springs or shakers to get out of order; it is noiseless, automatic, seif-cleaning and accurate; it is remarkable for simplicity, strength and for ease and perfection of work in the field. No one having use for a Seed Drill can afford to buy any other; it is the best.

Price, boxed, \$9.00.

Truckers, market-gardeners, onion growers and all who raise vegetables in quantity should supply themselves also with the "Planet Jr." Double Wheel Hoe (described below).
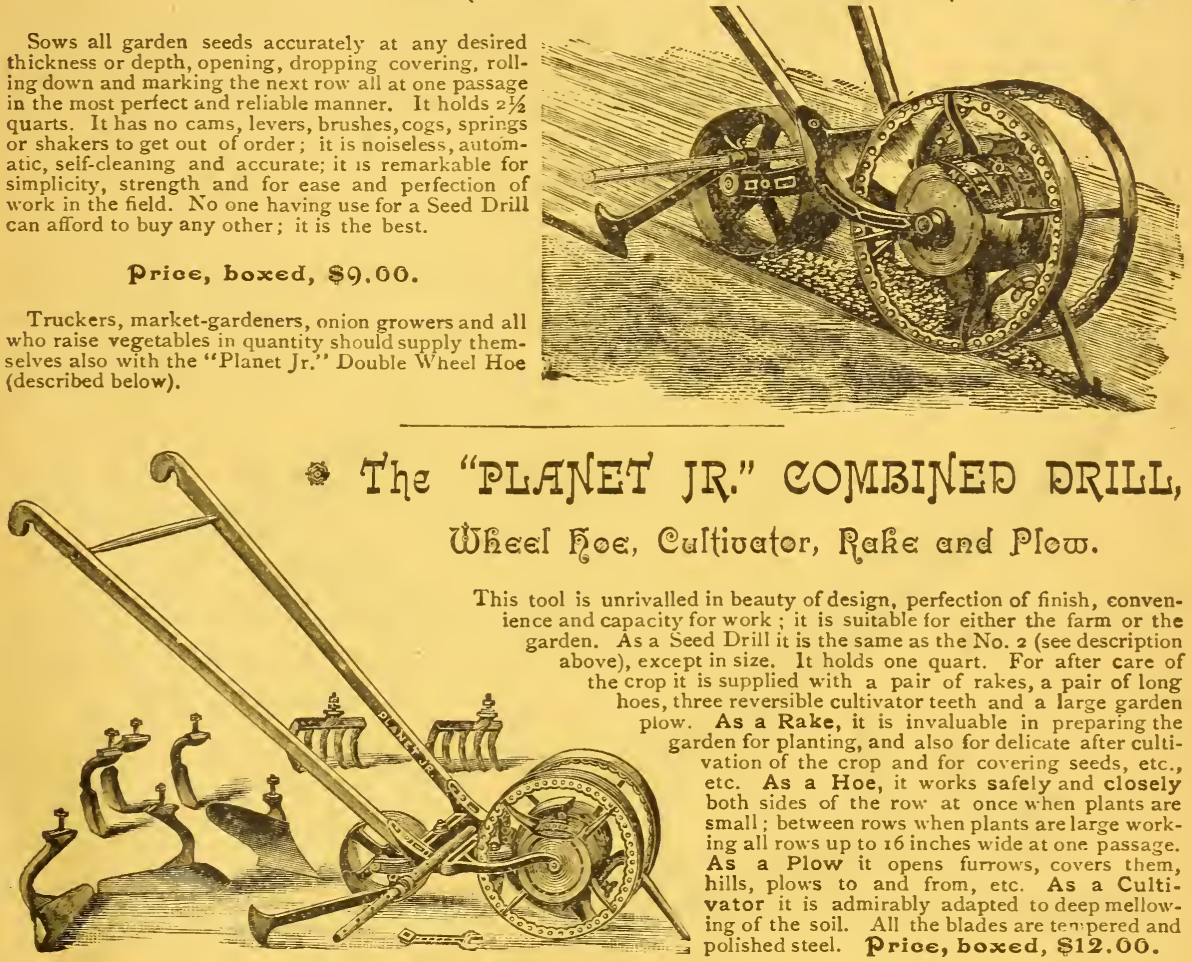

THE "PLANET JR." DOUBLE WHEEL HOE, CULTIVATOR, RAKE AND PLOW COMBINED.

This very popular tooi has been completely remodelled; is greatly simplified, strengthened mproved, and merits the thorougn admiration of every practical sardener. Each tool sent out with a pair of rakes, (new this season), a pair of hoes, four cultivator teetls and a pair of plows. The wheels are adjustable in height, and the arch is 14 inches high, thus enabling the operator to work both sides of the row at once, unless the plants grow over $x 8$ inches high; then the wheels can be set to run close together and the tool used between the rows. Leaf guards (detachable) go with each machine, to be used when plants extend into a wide row. Phis tool is light, very simple, made of the best material and highly finished and nothing can exceed the perfection and variety of work it performs.

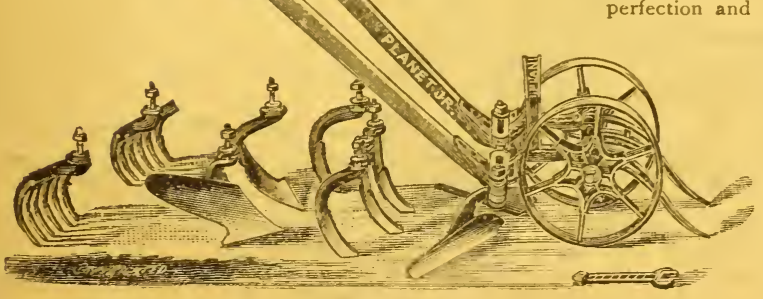

f.

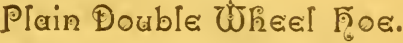

To meet a demand from some sections of the country, the "Planet Jr" Double Wheel Hoe, just described, will be offered with only one pair of Hoes and w-iturut leaf guards, under the name of "yPlanet Jr." Plain Double Wheel Hoe ats \$4.50. This will make a very effective and cheap tool for parties who have limite 


\section{The "Planet Jr." Single Wheel Foe,}

$\because \quad$ CULTIVATOR, RAKE AND PLOW COMBINED. $\quad \because$

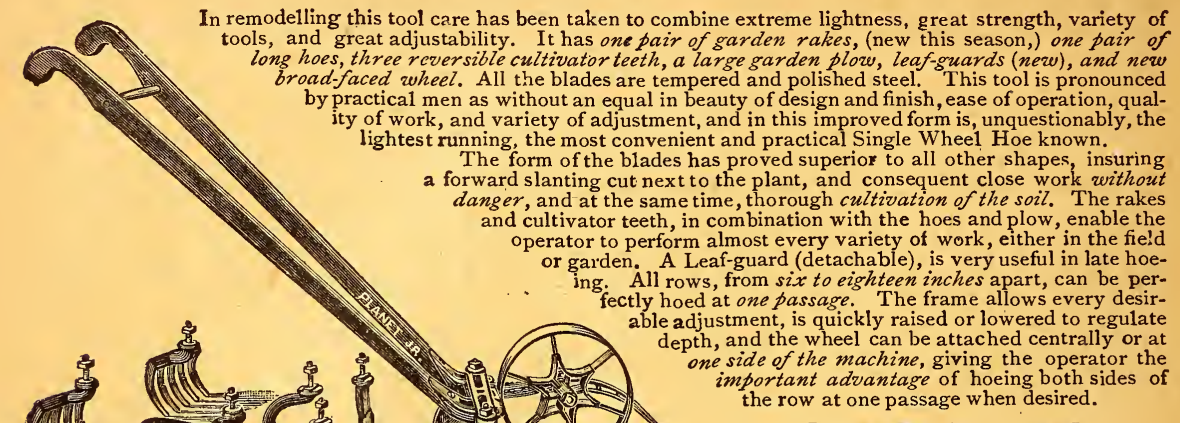

remodelling this tool care has been taken to combine extreme lightness, great strength, variety of long hoes, three reversible cultivator teeth, a f garden rakes, (new this season,) one pair of road-faced wheel. All the blades are tempered and polished steel. This tool is pronounced of work, and variety of adjustment, and in this improved form is, unquestionably, the The form of the blades has proved superior to all other shapes, insuring forward slanting cut next to the plant, and consequent close work without cultivator teeth, in combination with the hoes and plow, enable the or garden. A Leaf-guard (detachable), is very useful in late hoeAll rows, from six to eighteen inches apart, can be perAlly hoed at one passage. The frame allows every desirepth, and the wheel can be attached centrally or at ime of the machine, giving the operator the the row at one passage when desired.

Price, \$6.00, boxed.

噛

The "Fine-Fly" Single Wheel floe, Cultivaton plow Combined.

This convenient tocl has rapidly convinced practical gardeners of its high merits. It is also remodelled and has the broad-faced wheel. It combines lightness and strength with the greatest adjustability, while its highly polished and tempered steel tools make gardening comparatively a pleasure. The tools are all made after the most perfect models, and are

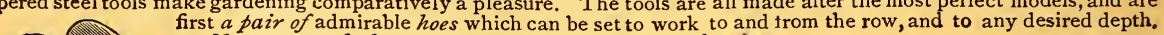
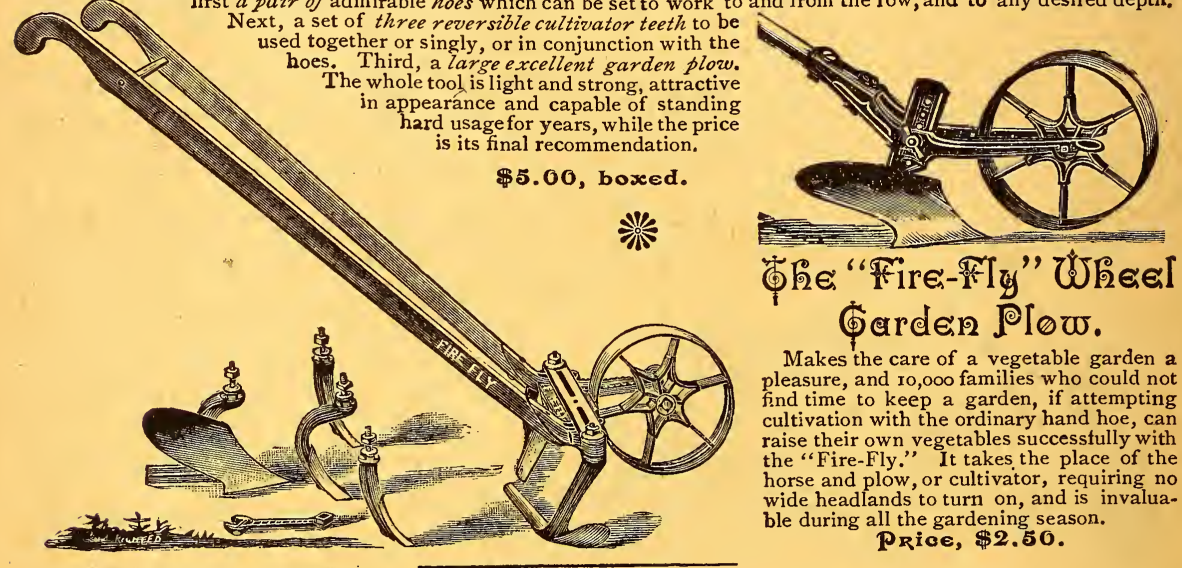

Makes the care of a vegetable garden a pleasure, and to,00o families who could not find time to keep a garden, if attempting cultivation with the ordinary hand hoe, can raise their own vegetables successfully with the "Fire-Fly." It takes the place of the horse and plow, or cultivator, requiring no wide headlands to turn on, and is invaluable during all the gardening season.

Price, \$2.50.

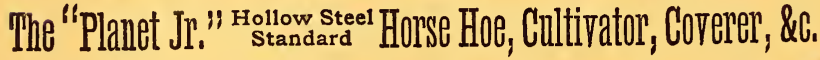

This Horse Hoe will have for 1888 many decided advantages over the oid "Planet Jr." or any other similar tool. It has been remodelled, and is now much stronger, simpler and better; wrought iron has been entirely discarded and its place taken by steel; the malleable fittings improved in design and strength. The Hollow Steel Standards have been remodelled to increase their strength and usefulness, and the plates will all be made with ti.e patent sleeve preventing the possibility of the bolts drawing through. A new and very superior design for the frame protected by patent will be introduced, and also a newly patented Star Wheel, which will make it an easy matter to distinguish these goods by appearance as well as by actual use from imitations. Priee, witb wobeel, \$11.00.

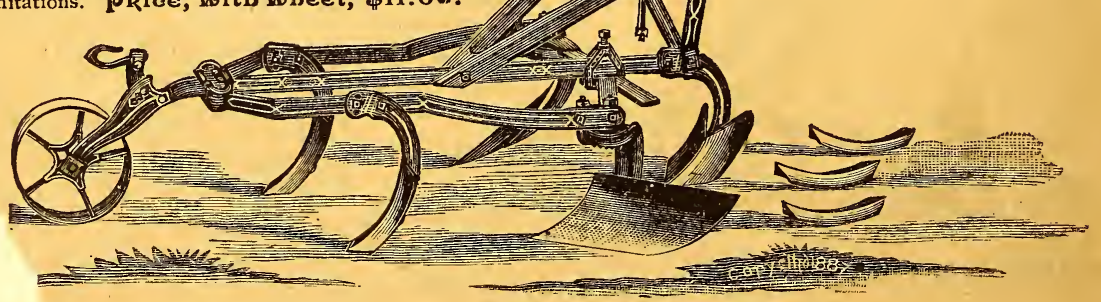




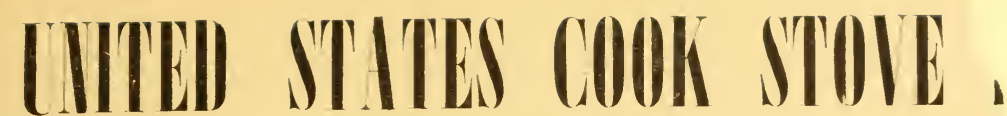

PRICE, $\$ 7.00$
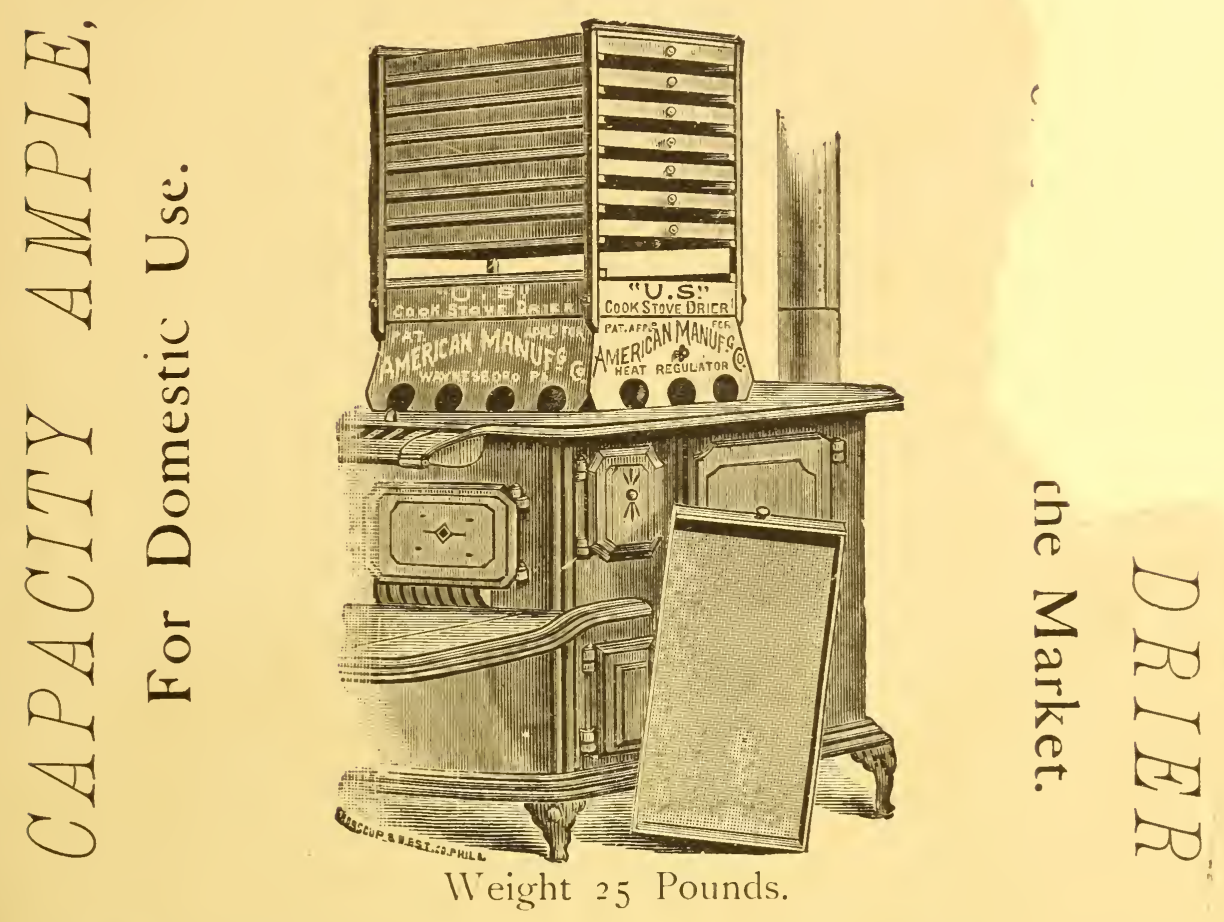

\section{ALIVAYS READY, EASILY HANILED, CHEAP, PORTA- BLE, DURABLE, EFFICIENT.}

This little Drier bas been built to meet the demand for a small, cheap machine, that can be used on any ordinarv Kitchen or Gasoline stove. A lady can easily handle it, and its capacity is sufficient for domestic use. It has eight trays which are interchangeable and supplied with galvanized wire cloth, which will not rust or discolor the fruit. It is light and compact. and can be shipped about as cheaply by Express as by Freight. For further particulars, send for circulars, \&c.

J. M. PHILIPS \& SONS, AG'Ts, Mercersburg, Pa.

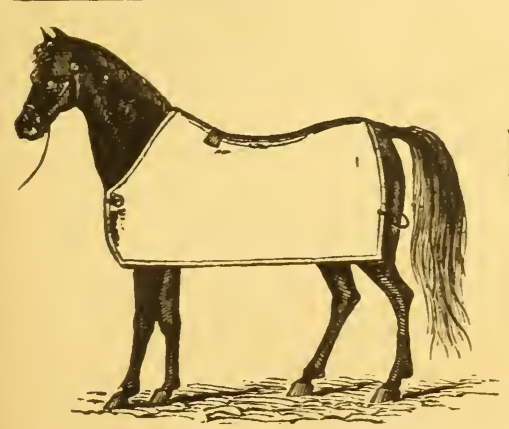

\section{VWVEAVERS}

\section{Horse and Cattle Powder}

Wholesale and Retail.

\section{S. GIIBERT,}

Chambersburg, $P a$. 


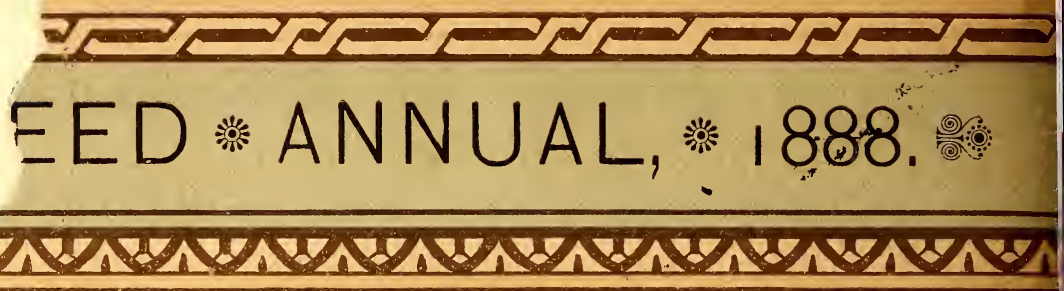
in and Flower Sepds.

Duteh Bulbs and Plants.

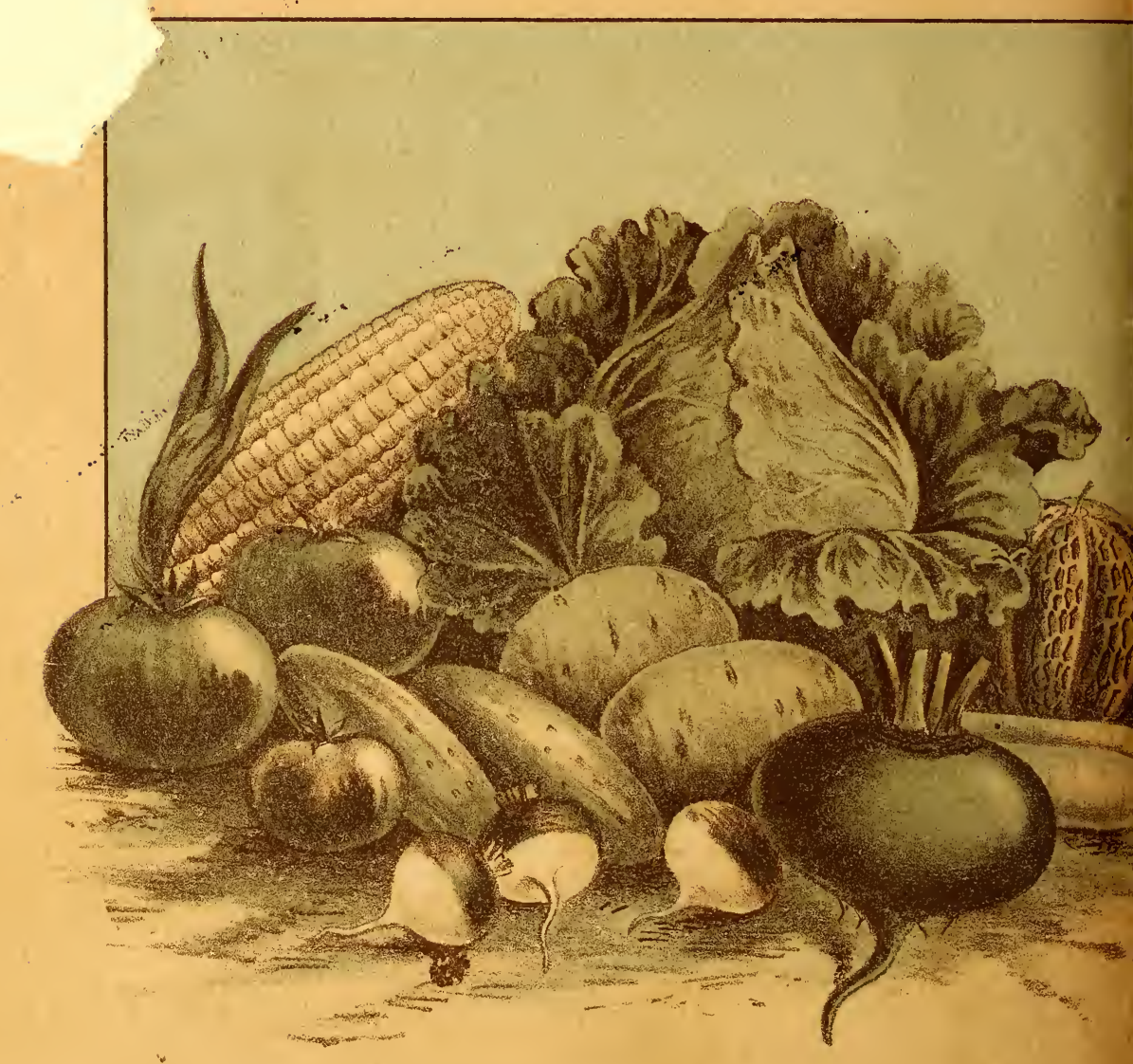

J. M. Philips \& Sons, 